\title{
10. CALCAREOUS NANNOFOSSIL BIOSTRATIGRAPHY OF THE CENTRAL EAST PACIFIC RISE, DEEP SEA DRILLING PROJECT LEG 92: EVIDENCE FOR DOWNSLOPE TRANSPORT OF SEDIMENTS1
}

\author{
Stephen Knüttel, Department of Geology, Florida State University ${ }^{2}$
}

\begin{abstract}
During Leg 92 of the Deep Sea Drilling Project, sediments containing calcareous nannofossils of latest Oligocene to Holocene age were recovered from 14 holes at six sites (597 to 602) along the East Pacific Rise. The combined sections yield a virtually complete record for the region, with a compressed upper Miocene to Pleistocene interval.

The nannofossil content of 14 U.S.N.S. Eltanin piston cores from the study area were also examined in order to supplement data generated during Leg 92 .

Two taxonomically new combinations are presented: Sphenolithus umbellus and Pontosphaera segmenta.

Assemblages of calcareous nannofossils juxtaposed in reversed stratigraphic order within the upper Miocene provide strong evidence for downslope transport of sediments along the East Pacific Rise during the Messinian. Narrow bands of dark metalliferous sediment of coccolith Zone $\mathrm{CN} 8 \mathrm{~b}$ alternate with normal light-colored, in situ, pelagic sequences of Zone CN9b. This may indicate more vigorous bottom current activity between 5.40 and $6.70 \mathrm{Ma}$.
\end{abstract}

\section{INTRODUCTION}

Leg 92 of the Deep Sea Drilling Project was the fourth cruise of the Glomar Challenger to operate in the South Pacific within the vicinity of the East Pacific Rise. As a hydrogeology leg, its primary objective was to investigate the hydrothermal activity present and to determine the nature and history of basalt-seawater interactions at the East Pacific Rise and on its flanks. The transect of Leg 92 holes along $19^{\circ} \mathrm{S}$ made possible the investigation of hydrothermal activity, while avoiding the excessive dilution of the hydrothermal sedimentary components by biogenic and terrigenous materials. The distribution, accumulation rates, and relationship to volcanic activity of these metalliferous sediments generated along the ridge crest are discussed in detail by Lyle et al. (this volume), Klinkhammer and Hudson (in press), Kennett et al. (1977), and Rea and Scheidegger (1979). Of particular interest was the rate at which hydrothermal components were incorporated in the sediment and whether any periodicity in that rate could be detected. Any such periodicity might be indicative of ridge volcanism, which, in turn, might be related to spreading rates. A secondary goal pertinent to this study was to recover sedimentary sections that could be used to interpret the biostratigraphic history within the area.

In all, 19 holes were drilled at six sites (Sites 597 to 602; Fig. 1). Of these, 14 holes yielded sediment that was examined for calcareous nannofossils in order to provide age control and information on the deposition history of the sediment sequences. These six sites, the first sites to be hydraulically piston cored along the East $\mathrm{Pa}-$ cific Rise, form a west-to-east transect along which sediments become increasingly thinner and younger toward

\footnotetext{
${ }^{1}$ Leinen, M., Rea, D. K., et al., Init. Repts. DSDP, 92: Washington (U.S. Govt. Printing Office).

2 Address: Department of Geology, Florida State University, Tallahassee, FL 32306.
}

the rise crest (Fig. 2). A total of only $247 \mathrm{~m}$ of sediment was recovered because of the thinness of the sedimentary cover. This thin blanket of sediment overlying basement is an expression of the area's low biological productivity within the South Pacific subtropical gyre (Okada and Honjo, 1973; Honjo and Okada, 1974).

The combined sediments from Leg 92 contain a relatively complete upper Oligocene through Holocene section. The oldest sediment was recovered at Site 597 and is latest Oligocene in age. Sediments at this site have a depositional history similar to other DSDP sites within the area (Fig. 1). Sites 74 and 75 from Leg 8 (Tracy, Sutton, et al., 1971), which lie north of Site 597, were drilled south of the equator as part of a north-south profile across the equatorial zone of high biological productivity. Site 319 from Leg 34 (Yeats, Hart, et al., 1976), was drilled in the Bauer Deep between the Galapagos Rise and the East Pacific Rise. These four sites all contain an early or middle Miocene to Pliocene interval with little or no carbonate.

Site 598 contains the most complete Neogene section cored to date along the East Pacific Rise south of the equator. Sediments are predominantly Miocene in age, with the Pliocene and Pleistocene interval restricted to the top $4.5 \mathrm{~m}$ of the hole. Sedimentation rates at Site 598 (see site chapter) are much lower than those at Site 80 (Hays, Cook et al., 1972), which was the only core from Leg 9 to be drilled south of the equator (Fig. 1); however, the latter was discontinuously cored. Both sites represent approximately the same interval of time.

One of the more interesting sediment sequences, which was recovered at Site 599, contained alternating light and dark bands of upper Miocene metalliferous pelagic sediments. Shipboard examination of the coccolith assemblages suggested that the darker material could have been reworked or displaced from shallower depths along the ridge. Particular attention is given to the examination and interpretation of this problematic sequence. A some- 


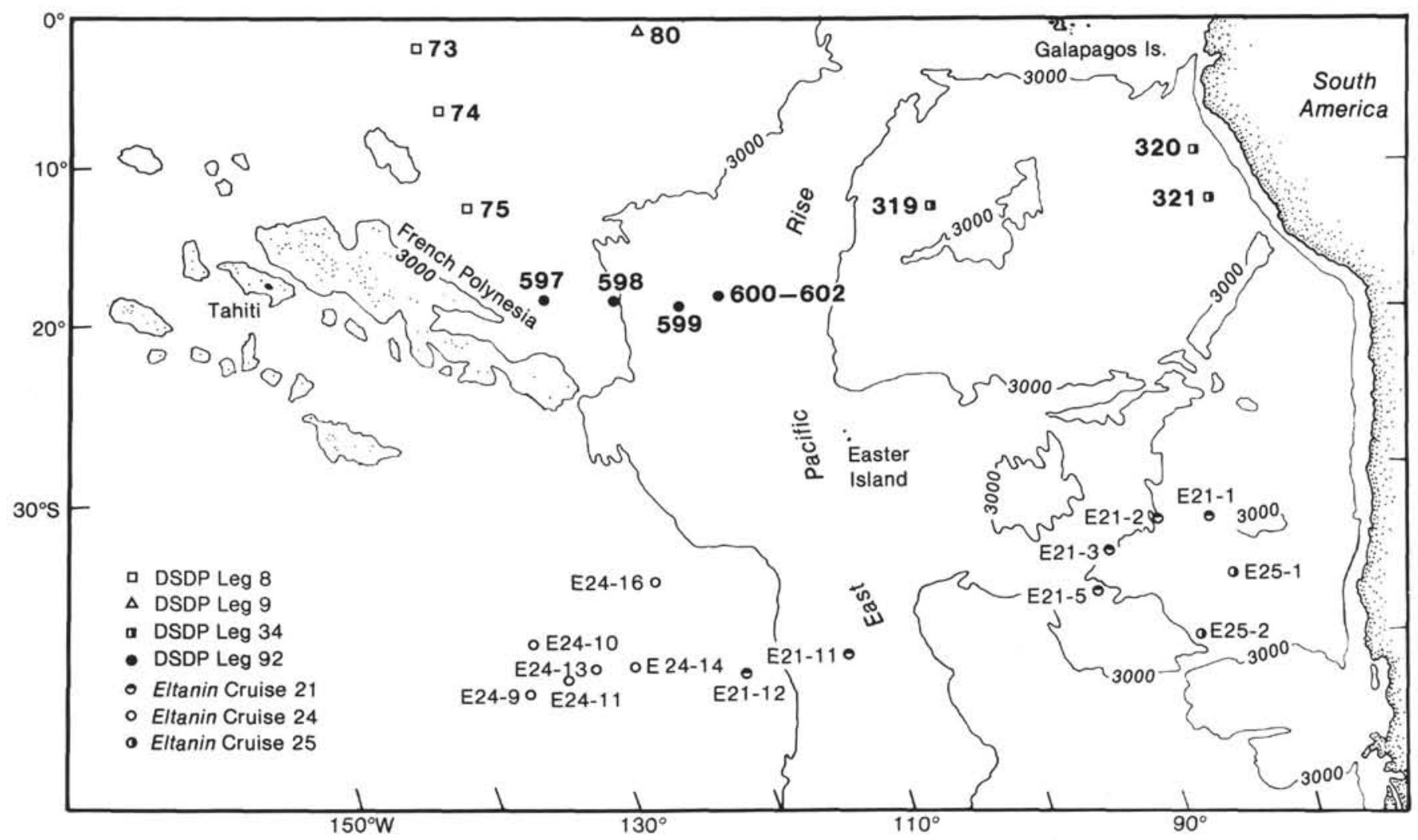

Figure 1. Location map for DSDP Leg 92 sites, other selected DSDP sites, and U.S.N.S. Eltanin cores.

what similarly reworked and/or redeposited sequence is present in the Pliocene of Site 600 .

Fourteen piston cores from the U.S.N.S Eltanin program were chosen to supplement the biostratigraphic data generated on this cruise. These cores are located south of the Leg 92 sites between $30^{\circ}$ and $41^{\circ} \mathrm{S}$ latitude (Fig. 1) and represent an area that has not been previously drilled by the Glomar Challenger.

The Pacific carbonate compensation depth (CCD) history determined from Leg 92 drill sites, constructed in part from the calcareous nannofossil data, is presented by Rea and Leinen (this volume) and summarized in Figure 3 . This curve is consistent with patterns of a CCD minimum in the Miocene, however, with depths approximately equal to those of other non-equatorial Pacific DSDP drill sites (van Andel et al., 1975; Broecker and Broecker, 1974).

The latitudes, longitudes, and water depths of the holes discussed in this chapter are as shown below:

\begin{tabular}{lccc}
\hline Hole & $\begin{array}{c}\text { Latitude } \\
(\mathrm{S})\end{array}$ & $\begin{array}{c}\text { Longitude } \\
(\mathrm{W})\end{array}$ & $\begin{array}{c}\text { Water depth } \\
(\mathrm{m})\end{array}$ \\
\hline 597 & $18^{\circ} 48.38^{\prime}$ & $129^{\circ} 46.23^{\prime}$ & 4166.5 \\
$597 \mathrm{~A}$ & $18^{\circ} 48.38^{\prime}$ & $129^{\circ} 46.23^{\prime}$ & 4162.6 \\
598 & $19^{\circ} 00.283^{\prime}$ & $124^{\circ} 40.61^{\prime}$ & 3699.0 \\
599 & $19^{\circ} 27.09^{\prime}$ & $119^{\circ} 52.88^{\prime}$ & 3654.0 \\
$600 \mathrm{C}$ & $18^{\circ} 55.70^{\prime}$ & $116^{\circ} 50.45^{\prime}$ & 3398.0 \\
601 & $18^{\circ} 55.22^{\prime}$ & $116^{\circ} 52.11^{\prime}$ & 3433.0 \\
602 & $18^{\circ} 54.41^{\prime}$ & $116^{\circ} 54.68^{\prime}$ & 3535.0 \\
\hline
\end{tabular}

The calcareous nannofossil species considered in this chapter are listed in Appendix A, and a systematic pale- ontology section including the new combinations is given in Appendix B.

\section{METHODS}

All samples used in this study were prepared by use of a simple settling technique similar to that of Hay (1977). This settling technique helped to eliminate the larger particles, RSO's (red brown to yellow brown semi-opaque oxides; Yeats, Hart, et al., 1976) and foraminifers. It also removed some of the clays present, which reduced flocculation on the slide and made it possible to disperse the nannofossils more evenly.

The basic technique is as follows:

1. Approximately $0.5 \mathrm{~g}$ of sediment was placed in a $100-\mathrm{ml}$ beaker, and $40 \mathrm{ml}$ of a $3-5 \%$ Calgon $\left[\left(\mathrm{NaPO}_{3}\right)_{6}\right]$ solution were added.

2. After the sediment was disaggregated, the solution was agitated and allowed to settle for $30 \mathrm{~s}$.

3. The supernatant was then decanted into another 100 -ml beaker and allowed to stand for $45 \mathrm{~min}$.

4. After settling, the supernatant was decanted by use of a pipette and discarded.

5. The residual sediment was then resuspended with approximately $10 \mathrm{ml}$ of water and smear slides were made.

Each slide was made with Canada balsam as a mounting medium and was examined with a light microscope. Approximately five traverses across the slide were made at $1200 \times$ magnification. Pleistocene materials were examined at $1562 \times$ magnification, and the abundances were adjusted accordingly.

Estimates of abundance for individual species of nannofossils are as follows:

$\mathrm{V}=$ very abundant; $100+$ specimens per field of view

$\mathrm{A}=$ abundant; 11 to 100 specimens per field of view

$\mathrm{C}=$ common; 1 to 10 specimens per field of view

$\mathrm{F}=$ few; 1 specimen per 2 to 10 fields of view

$\mathrm{R}=$ rare; 1 specimen per 50 fields of view

$\mathrm{P}=$ present $; 1$ specimen 50 or more fields of view

$\mathrm{B}=$ barren; essentially no nannofossil present.

The abundance of calcareous nannofossils is also estimated by using this scale. Lower-case letters are not used to indicate reworked 


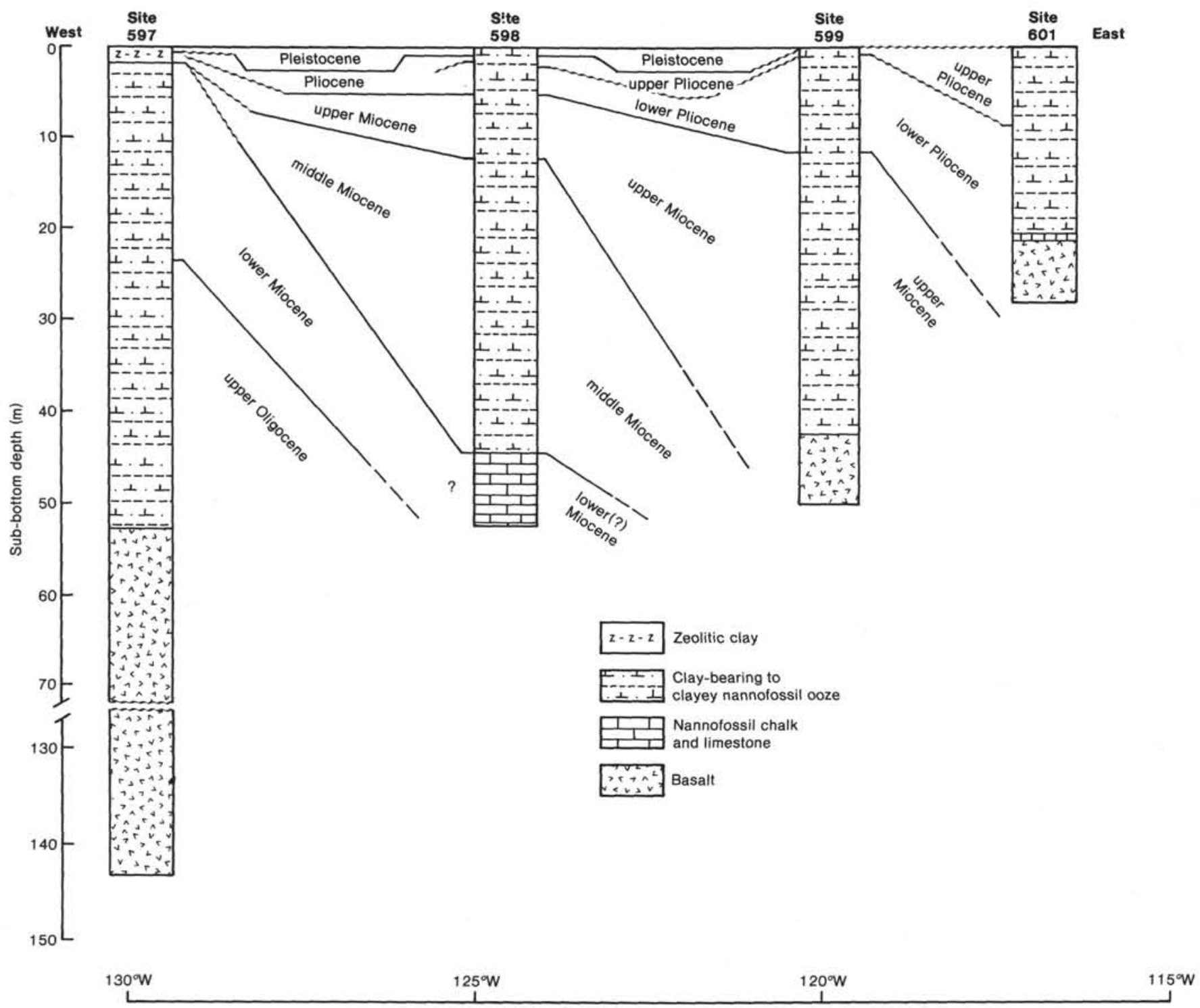

Figure 2. Generalized cross section of cores obtained during Leg 92. The East Pacific Rise is located approximately $350 \mathrm{~km}$ east of Site 601 .

taxa, because in some cases (see Site 599) the amount of reworked material is uncertain and different conclusions can be drawn from the data presented.

Preservation of calcareous nannofossils in each sample is recorded as follows:

$\mathrm{G}=$ good: specimens show little effects of overgrowth and/or dissolution.

$\mathrm{M}=$ moderate: specimens show some effects of overgrowth and/ or dissolution; identification of taxa is sometimes impaired.

$\mathrm{P}=$ poor: specimens show effects of advanced overgrowth and/or dissolution; most taxa are questionably identified.

In addition to these symbols, a (+) or $(-)$ is added to indicated predominant overgrowth $(+)$ or dissolution $(-)$. The lack of either symbol indicates that the effects of overgrowth and dissolution are approximately equal.

The preservation categories used here correspond to the Bukry (1973a) preservation scale as follows: good $=(1)$, moderate $=(2$ and 3$)$, poor $=(3.5$ and 4$)$ barren $=(5)$.

At least one sample was examined from each section of core. Additional samples were taken where the stratigraphic section was compressed or where sedimentary contacts were present. In some cases, subsamples from the interstitial water samples were provided by the onboard water chemists after pore-water extraction. These samples were taken from the bottom of the $10-$ or $15-\mathrm{cm}$ interval. The complete interval is used to denote these samples.
All sample depths referred to within this report are sub-bottom depths.

\section{CALCAREOUS NANNOFOSSIL BIOSTRATIGRAPHY AND ZONATION}

The zonation scheme used for Cenozoic age determinations in this report is the low-latitude zonation of Bukry $(1973 b, 1975)$ and Okada and Bukry (1980). The absolute ages and epoch and stage boundaries are from Haq (1984), which Haq correlates with the Bukry scheme as shown in Figures $4 \mathrm{~A}$ and $4 \mathrm{~B}$. One Haq boundary has been modified by correlating the Pliocene/Pleistocene boundary with the extinction of Calcidiscus macintyrei (Backman et al., 1983). The Oligocene/Miocene boundary has also been placed within the CN1a and b Subzones (Bukry, 1973b, 1975; Okada and Bukry, 1980) instead of between the CP19 and CN1 Zones (Haq, 1984; Haq and Takayama, 1984). In one instance, Haq and Takayama (1984) correlate the last occurrence of Dictyococcites bisectus with the Oligocene/Miocene boundary. This datum would delineate the boundary between the 


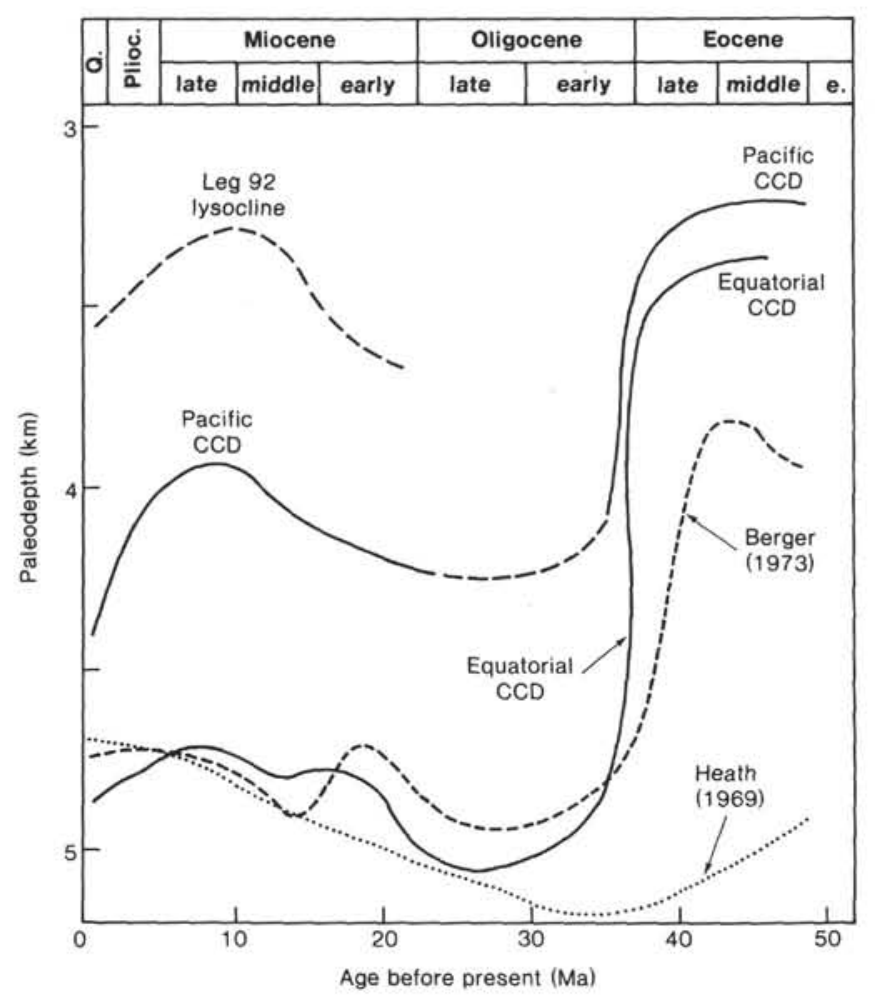

Figure 3. Pacific calcite compensation depth history after van Andel et al. (1975), with the addition of data generated during Leg 92 (Rea and Leinen, this volume). Late and middle Miocene section of the curve is figured from proximity to the CCD within Site 598.

CN1 (Triquetrorhabdulus carinatus) Zone and the CP19 (Sphenolithus ciperoensis) Zone. The last occurrence of $S$. ciperoensis is used here, however, as the primary datum for delineation of the boundary between the CP19/ CN1 Zones. At Site 597, the last occurrence of D. bisectus is found higher (in the section) than the last occurrence of $S$. ciperoensis, and the CP19/CN1 boundary, therefore, could not be correlated with the Oligocene/ Miocene boundary. The last occurrence of $D$. bisectus is used to mark the Oligocene/Miocene boundary (Edwards, 1973). Thus, that boundary falls within the $\mathrm{CN1a} / \mathrm{b}$ Subzones.

\section{Site 597}

Site 597 , located approximately $2100 \mathrm{~km}$ east of Tahiti, is the westernmost site cored during Leg 92 and the farthest of the six sites from the East Pacific Rise. Of the four holes cored at this site, only Holes 597 and $597 \mathrm{~A}$, which were cored continuously by hydraulic piston corer, were examined in detail for their nannofossil content. Sediments from these holes range in age from latest Oligocene to early or middle Miocene, with a thin Holocene interval at the top (Tables 1 and 2). These sediments are similar in age to those found at Site 75 (Bukry, 1971b), which lies to the northwest of Site 597; Site 75 has a slightly older basement sediment age.

Nannofossil preservation is moderate throughout most of the cored interval, except for the upper approximately $10 \mathrm{~m}$, where preservation is poor. Nannofossils are absent between $0.3 \mathrm{~m}$ and $1.4 \mathrm{~m}$. The assemblage shows signs of strong dissolution down to approximately $10 \mathrm{~m}$. Most placoliths are present only as isolated rims. The effects of dissolution decrease downhole, where overgrowth predominates (approximately $23.8 \mathrm{~m}$ down to basement).

The upper $0.2 \mathrm{~m}$ to $0.3 \mathrm{~m}$ of both holes contains calcareous nannofossils from the uppermost Quaternary Emiliania huxleyi Zone (CN15). Specimens of E. huxleyi are rare and poorly preserved. Gephyrocapsa oceanica and Calcidiscus leptoporus are the most common forms observed. The remainder of the assemblage is comprised primarily of Ceratolithus cristatus, Rhabdosphaera clavigera, and Coccolithus pelagicus. Various older species of nannoliths, such as Discoaster deflandrei, $\mathrm{Cy}$ clicargolithus floridanus, and Sphenolithus moriformis, are reworked into the interval. Below this interval, from approximately $0.3 \mathrm{~m}$ to $1.4 \mathrm{~m}$, is a layer of zeolitic clay that is essentially barren of calcareous nannofossils. The ages of the bounding nannofossil-rich sediments indicate that this unit represents a period of time from the early or middle Miocene to the Holocene.

The early or middle Miocene Sphenolithus heteromorphus Zone and Helicosphaera ampliaperta Zone (CN4 and 3) are represented in Hole 597 between Samples 597$1-2,17-18 \mathrm{~cm}$ and $597-1-3,56-57 \mathrm{~cm}(1.7$ and $3.6 \mathrm{~m})$ and in Hole 597A between Samples 597A-1-2, 32-33 cm and 597A-1-3, 11-12 cm (1.8 and $3.1 \mathrm{~m})$. Specimens of $S$. heteromorphus are common within the interval; however, dissolution has decreased the height of most individuals to between 4 and $6 \mu \mathrm{m}$. The boundary between the two zones, which approximates the early/middle Miocene boundary, was not delineated because the section was very compressed. The absence of $H$. ampliaperta and the unclear termination of the $D$. deflandrei acme also made separation difficult. The alternate marker species, Calcidiscus macintyrei, which is present only as distal shields (37 or more elements), was found to have its first occurrence within the $S$. belemnos Zone (Samples 597-2-6, 56-57 cm and 597A-2-5, 145-146 cm). However, the presence of more common long-rayed discoasters within the upper samples (597-1-1, 140-141 cm and 597A-1-1, 142-143 cm) makes it impossible to rule out an earliest middle Miocene age.

Sediments between Sections 597-1,CC and 597-2,CC (4.6 and $14.2 \mathrm{~m}$ ) in Hole 597 and Samples 597A-1-3, 56$57 \mathrm{~cm}$ and 597A-2-5, 145-146 cm (3.6 and $12.1 \mathrm{~m})$ in Hole 597A are placed within the $S$. belemnos Zone (CN2). $S$. belemnos occurs sporadically throughout the zone and is rare or absent in most samples. Specimens are most common in Section 597-2, CC but are still only few in abundance. $D$. druggii, which occurs discontinuously at Site 597, has its second abundance peak (uphole) within this zone (Section 597-1,CC through Sample 597-2-3, $56-57 \mathrm{~cm}$ and Samples 597A-1-3, 56-57 cm through 597A$2-2,100-101 \mathrm{~cm}$ ). The discontinuous nature of $D$. druggii has been similarly reported in other DSDP sites (Bukry, 1975; 1976). The majority of the remaining assemblage is comprised of $D$. deflandrei, Cyclicargolithus floridanus, and S. moriformis.

The earliest abundance peak of $D$. druggii occurs between Samples 597-3-1, 56-57 cm and 597-3-4, 56-57 cm (14.8 and $19.3 \mathrm{~m}$ ) in Hole 597 and Samples 597A-2-6, 
$145-146 \mathrm{~cm}$ and $597 \mathrm{~A}-3-3,56-57 \mathrm{~cm}(13.6$ and $17.8 \mathrm{~m})$ in Hole 597A. These sediments are placed within the upper D. druggii Subzone of the Triquetrorhabdulus carinatus Zone (CN1c). S. belemnos is absent, and $T$. carinatus, which is only rarely noted in the above zone, becomes more common downhole. Coccolithus miopelagicus and Cyclicargolithus abisectus also become more numerous within the interval.

The lower two subzones of the $T$. carinatus Zone (CN1a and $b$ ) were not delineated at this site because of the unclear termination of the $C$. abisectus acme. Sediments between Samples 597-3-4, 139-140 cm and 597-4-3, 56$57 \mathrm{~cm}(20.1$ and $27.4 \mathrm{~m})$ in Hole 597 and between Samples 597A-3-3, 148-149 $\mathrm{cm}$ and 597A-4-3, 56-57 cm (18.7 and $27.4 \mathrm{~m}$ ) in Hole $597 \mathrm{~A}$ are assigned to these subzones. Several changes in the nannofossil assemblage occur within the interval, many of which are observed within the population of the genus Sphenolithus. Specimens of $S$. moriformis become increasingly numerous in samples below $25 \mathrm{~m}$. Larger forms of the species, $>5 \mu \mathrm{m}$, begin to outnumber smaller varieties. $S$. dissimilis and $S$. conicus are more consistently observed within this interval. However, the abundance of these two species plotted on the range chart may not be indicative of their true abundance, because questionable forms are assigned to $S$. moriformis. Because of the many intermediate forms observed, it is possible that $S$. dissimilis and $S$. conicus represent preservationally altered forms of $S$. moriformis. Restricted occurrences of S. capricornutus and $S$. delphix are noted between Samples 597-3-6, 56-57 cm and 597-4-1, 56-57 cm (22.3 and $24.4 \mathrm{~m})$ in Hole 597 and between Samples 597A-3-4, 56-57 cm and 597A$3-5,56-57 \mathrm{~cm}(19.3$ and $20.8 \mathrm{~m})$ in Hole 597A.

The combined last appearance of Dictyococcites bisectus, Clausicoccus fenestratus, and S. umbrellus occurs in Section 597-3,CC (23.8 m) and Sample 597A-3-5, $56-57 \mathrm{~cm}(20.8 \mathrm{~m})$. The extinction of these three species is used to approximate the Miocene/Oligocene boundary, which Bukry $(1973 \mathrm{~b}, 1975)$ and Okada and Bukry (1980) place within the range of the Discoaster deflandrei Subzone and Cyclicargolithus floridanus Subzone (CNla and b). Haq (1984), however, places the Miocene/ Oligocene boundary at the end of the $S$. ciperoensis Zone as defined on the last Dictyococcites bisectus. The last appearance of $S$. ciperoensis, rather than D. bisectus, is used to define the termination of the CP19 Zone in this study.

Calcareous nannofossils found in the lower half of the sediment column, from Samples 597-4-3, 149-150 cm and $597 \mathrm{~A}-4-3,149-150 \mathrm{~cm}(28.3 \mathrm{~m})$ to basement in both holes, are placed within the uppermost Oligocene $S$. ciperoensis Zone, D. bisectus Subzone (CP19b). Basal sediments from Hole 597C (597C-1,CC) also indicate a similar age. Specimens of $S$. ciperoensis are few to common in most samples, and $S$. distentus was not observed. Placoliths are dominated by Cyclicargolithus floridanus and C. abisectus, the latter becoming more numerous than the former with increasing age. Discoasters also become increasingly overgrown, and their numbers decrease in abundance with age. Most forms are presumed to be $D$. deflandrei. The presence of the holococcolith Zygrhab- lithus bijugatus, observed throughout the zone, probably indicates deposition well above the calcite compensation depth (Edwards and Perch-Nielsen, 1974; Wise and Wind, 1976).

\section{Site $\mathbf{5 9 8}$}

Site 598 is approximately $550 \mathrm{~km}$ east of Site 597 and slightly southeast of the Austral Fracture Zone (Fig. 1). Sediments recovered from this site range in age from early or middle Miocene to Holocene and represent the most complete Neogene section cored along the East Pacific Rise south of the equator. The sediments are predominantly Miocene in age, with the Pliocene through Holocene section being restricted to the top $4.5 \mathrm{~m}$ of Core 598-1 (Table 3). The highly compressed nature of this interval made the separation of subzones and some zones difficult. The presence of hiatuses could not be ascertained.

Samples 598-1-1, 5-6 cm and 598-1-1, 56-57 cm contain Quaternary nannofossils within Zones $\mathrm{CN} 14$ and CN15. The presence of Emiliania huxleyi in Sample 598$1-1,5-6 \mathrm{~cm}(0.1 \mathrm{~m})$ places it within the $E$. huxleyi Zone (CN15), and its absence in Sample 598-1-1, 56-57 cm $(0.6 \mathrm{~m})$, along with the presence of Gephyrocapsa oceanica and Pseudoemiliania lacunosa, places Sample 598$1-1,56-57 \mathrm{~cm}$ within the $G$. oceanica Zone (CN14). These zones are also characterized by the presence of Calcidiscus leptoporus, Rhabdosphaera clavigera, Ceratolithus cristatus, and Coccolithus pelagicus. Preservation is good, and fossils are abundant.

Discoasters have their last occurrence in Sample 598$1-1,140-150 \mathrm{~cm}(1.5 \mathrm{~m})$, and sediments through Sample $598-1-2,56-57 \mathrm{~cm}(2.1 \mathrm{~m})$ are placed in the late Pliocene Discoaster brouweri Zone (CN12). D. brouweri and D. pentaradiatus are common to abundant in these samples, with $D$. surculus being more numerous in the lower sample. Specimens of $D$. asymmetricus and $D$. tamalis are only observed in Sample 598-1-2, 56-57 cm, which may indicate the lower $D$. tamalis Subzone (CN12a). The presence of Reticulofenestra pseudoumbilica, which is rare within the lower sample, however, makes it impossible to rule out a late early Pliocene age (CN11), if it is assumed that there is no reworking. Preservation is good throughout the interval, with the effects of dissolution increasing downhole. Fine structure, such as the rims of Pseudoemiliania lacunosa, are etched and of poorer preservation.

An early Pliocene age of sediments between Samples $598-1-2,142-143 \mathrm{~cm}$ and $598-1-3,140-150 \mathrm{~cm}$ (2.9 and $4.5 \mathrm{~m}$ ) is indicated by the presence of Amaurolithus spp. in the absence of $D$. quinqueramus, which defines the A. tricorniculatus Zone (CN10). The first occurrence of Ceratolithus rugosus in Sample 598-1-2, 142-143 cm (CN10c) and the last occurrence of Triquetrorhabdulus rugosus in Sample 598-1-3, 140-150 cm, rarely observed in 598-1-3, 56-57 cm (CN10a) further help subdivide the zone. Members of the genus Amaurolithus found in all samples from this interval include $A$. tricorniculatus, $A$. primus, and $A$. delicatus, all of which are few to rare in abundance. A. amplificus is observed only in the lower sample (598-1-3, 140-150 cm). Specimens of R. pseudo- 


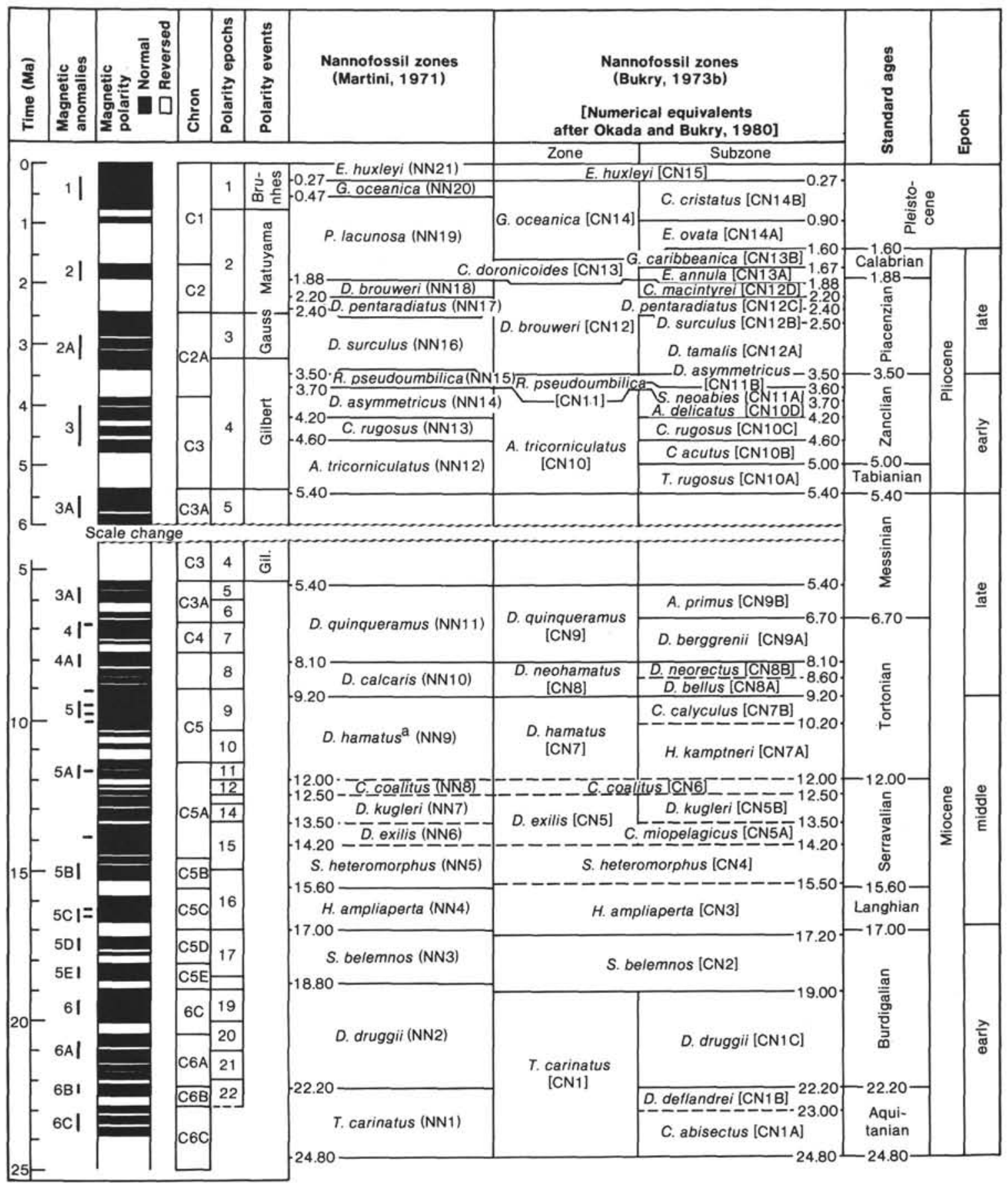

Modified

Figure 4. Correlations between magnetostratigraphy, chronostratigraphic stages, and nannofossil zones after Martini (1971), Bukry (1973b), and Okada and Bukry (1980). From Haq (1984). A. Pleistocene to early Miocene. B. Early Miocene to Maestrichtian.

umbilica are common, and Sphenolithus abies and $S$. neoabies decrease in number from few to rare with increasing age. Nannofossil preservation is moderate and shows increasing effects of dissolution with age. Rare specimens of $D$. moore $i$ are noted within this zone, and because of the lack of other Miocene species, it is assumed not to be reworked.
Sediment between Sample 598-1-4, 56-57 cm and Section $598-1, \mathrm{CC}(5.1$ and $6.2 \mathrm{~m})$ is placed within the upper Miocene $D$. quinqueramus Zone, A. primus Subzone (CN9b). Characteristic species present within the zone include $A$. primus, $A$. delicatus, $A$. amplificus, $D$. quinqueramus, $D$. surculus, $D$. brouweri, and $D$. variabilis. Preservation among placoliths begins to show signs of 
B

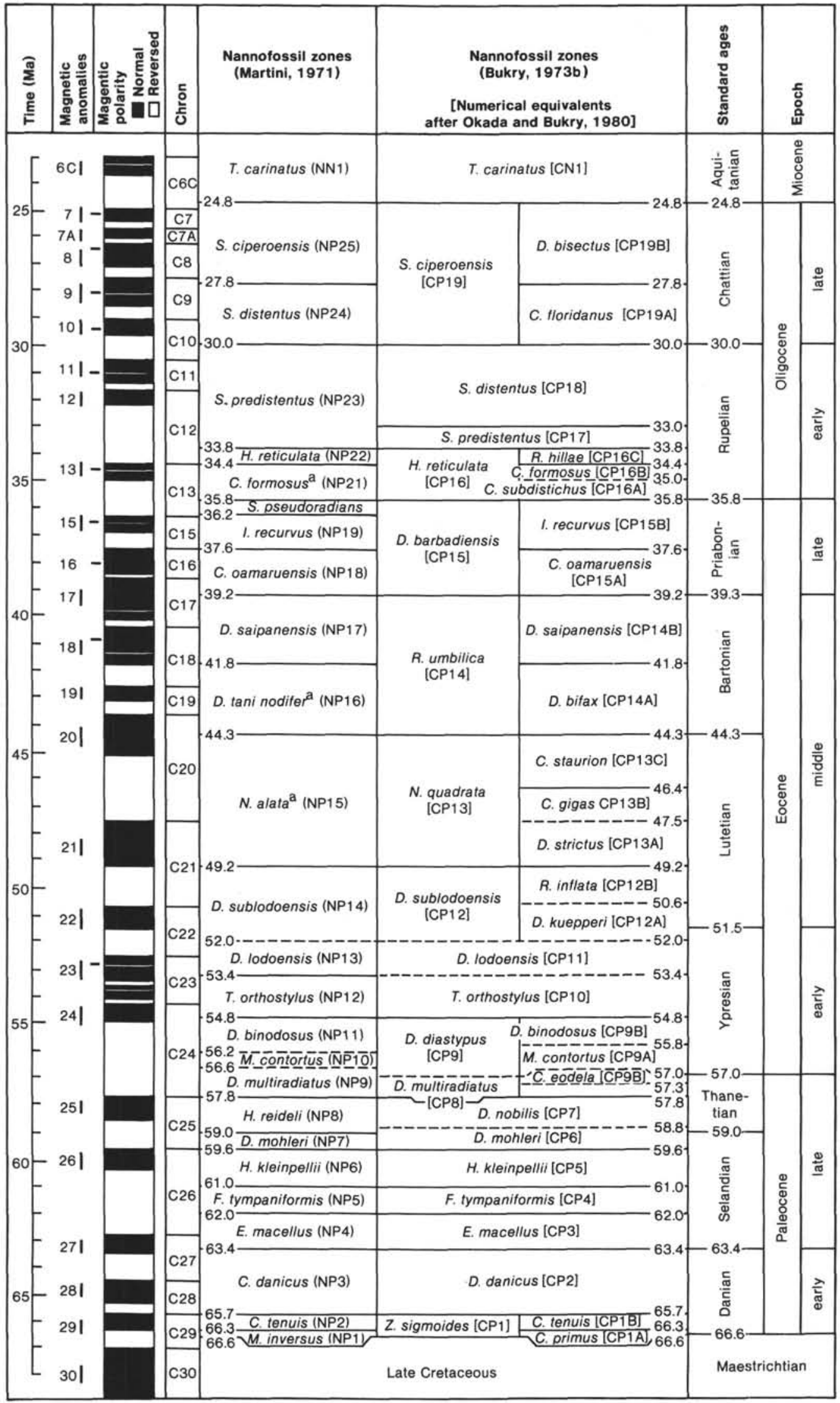

${ }^{\mathrm{a}}$ Modified

Figure 4 (continued). 
Table 1. Distribution of calcareous nannofossils in Hole 597.

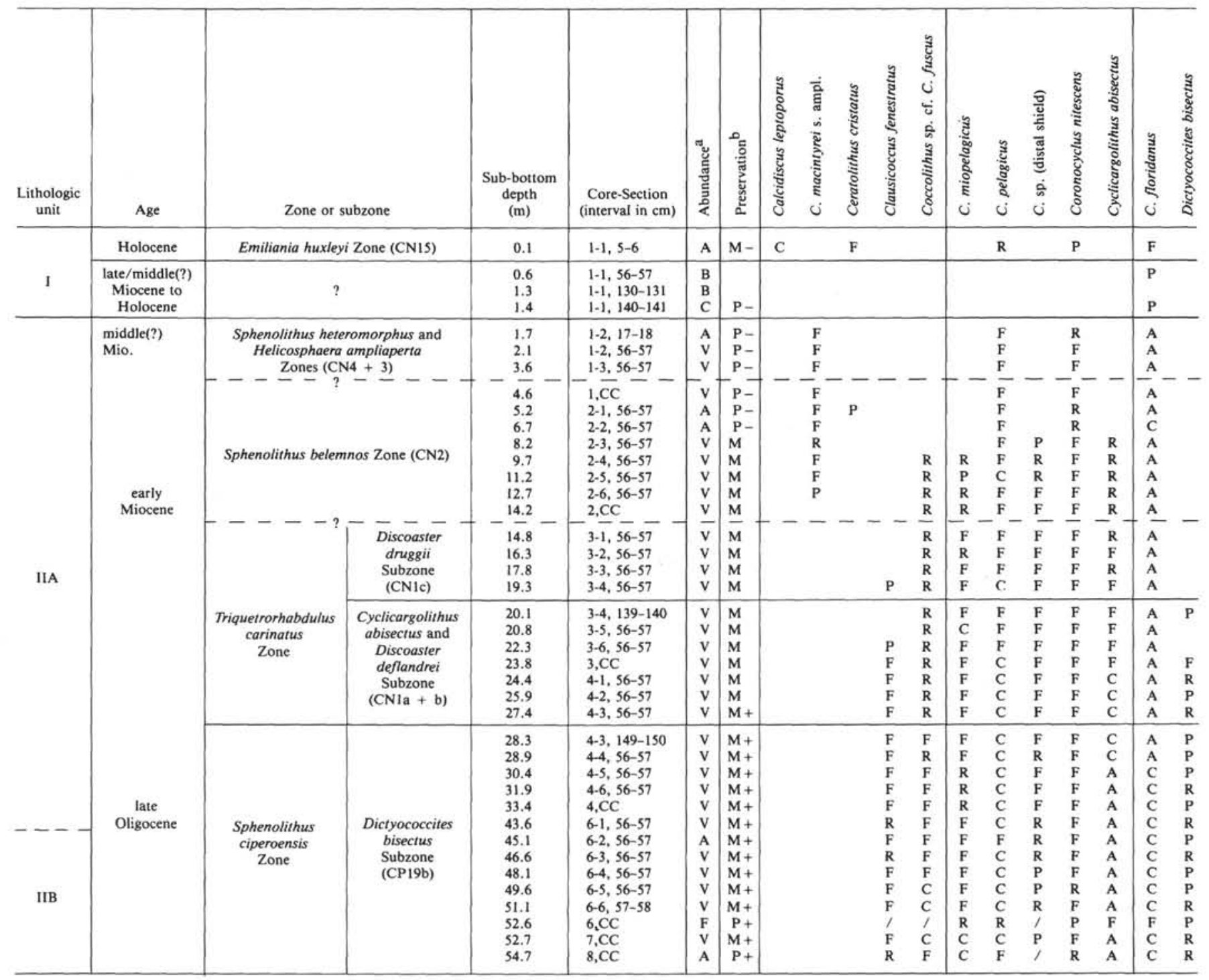

${ }^{\mathrm{a}} \mathrm{V}=$ very abundant, $\mathrm{A}=$ abundant, $\mathrm{C}=$ common, $\mathrm{F}=$ few, $\mathrm{R}=$ rare, $\mathrm{P}=$ present.

${ }^{\mathrm{b}} \mathrm{M}=$ moderate, $\mathrm{P}=$ poor; $+=$ predominant overgrowth, $-=$ predominant dissolution.

advanced dissolution within this zone. Specimens of $R$. pseudoumbilica decrease in number with age and are more poorly preserved; Calcidiscus macintyrei and C. leptoporus are observed primarily as isolated rims. The genus Sphenolithus is virtually absent.

Sediments from the upper half of Core 598-2, between Samples 598-2-1, 56-57 cm and 598-2-3, 56-57 cm (6.8 and $9.8 \mathrm{~m}$ ), are contained within the lower subzone of the $D$. quinqueramus Zone and the upper subzone of the $D$. neohamatus Zone (CN9a and 8b). Delineation of the zones (CN9 and CN8) was not attempted because of the disturbed nature of the sediment within Section 5982-2 and Section 598-2-3 and the paucity of the index species, $D$. berggrenii and $D$. surculus. The top of the interval is defined by the first occurrence of $A$. primus, the bottom by the last occurrence of Catinaster calyculus. The last occurrence of $C$. calyculus was used to approximate the $\mathrm{CN} 8 \mathrm{a} / 8 \mathrm{~b}$ boundary because of the absence of $D$. neorectus, which defines the base of the $\mathrm{CN} 8 \mathrm{~b}$
Subzone. Specimens of $D$. neohamatus and Minylitha convallis, which are more characteristic of the CN8b Subzone, are present in all samples within the interval, and the possibility of a minor hiatus cannot be ruled out.

The upper/middle Miocene boundary in Hole 598 is placed within the lower half of Core 598-2 between Samples 598-2-4, 140-150 $\mathrm{cm}$ and 598-2-5, 56-57 cm (12.2 and $12.8 \mathrm{~m}$ ). The rare guide species $D$. hamatus has its last occurrence within Sample 598-2-5, 56-57 cm. Samples 598-2-4, 56-57 cm and 598-2-4, 140-150 cm (from $12.2 \mathrm{~m}$ up to $11.3 \mathrm{~m}$ ), therefore, are placed within the lower subzone of the D. neohamatus Zone (CN8a), and samples below Sample 598-2-5, 56-57 cm (12.8 m) down to Section $598-2, C C(15.8 \mathrm{~m})$ are placed within the $D$. hamatus Zone (CN7). The genus Catinaster is abundant in most samples (598-2,CC through 598-2-4, 140-150 cm), and $C$. calyculus, which has its last occurrence in Sample 598-2-4, 56-57 cm outnumbers $C$. coalitus within the CN8a Subzone. The nannofossils observed within 
Table 1 (continued).

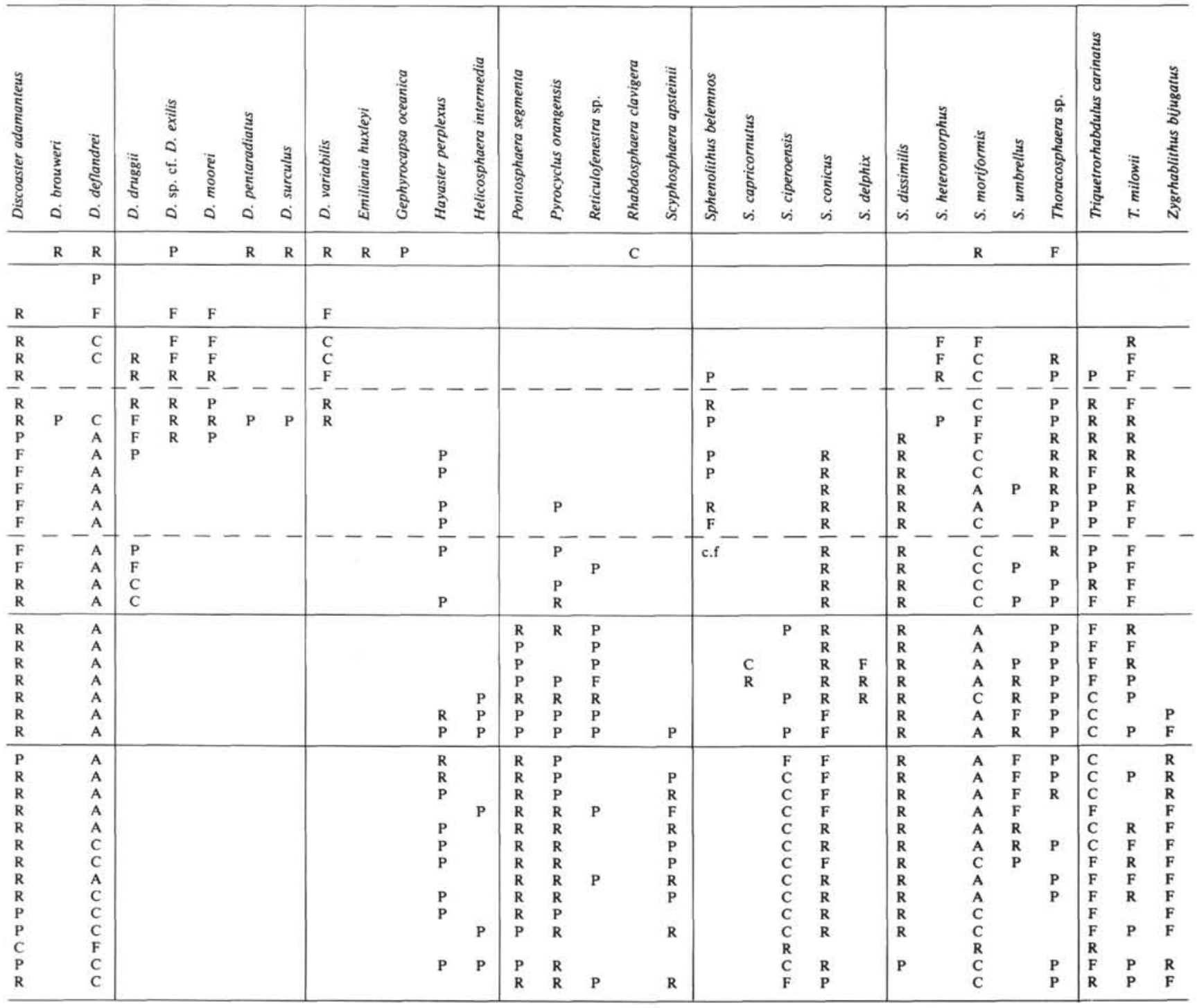

these two zones show the effects of strong dissolution; almost all placoliths are dissolved, with only a few isolated shields remaining. Resistant species of Discoaster and Catinaster, which are less affected, dominate the assemblage.

The middle Miocene $C$. coalitus Zone (CN6) is only noted for Sample 598-3-1, 56-57 cm (16.4 m). The zone is identified by sparse $C$. coalitus in the absence of $D$. hamatus. The rare occurrence of $D$. exilis and Coccolithus miopelagicus also characterizes the zone. The condensed nature of the interval, along with a change in preservation, indicates deposition in proximity to the carbonate compensation depth and/or the presence of a minor hiatus.

Nannofossil preservation changes noticeably between Samples 598-3-1, 56-57 cm and 598-3-3, 56-57 cm (16.4 and $19.4 \mathrm{~m}$ ). Placoliths increase slightly in number, and discoasters become more poorly preserved. Below $19.4 \mathrm{~m}$ discoasters are poorly preserved, and most long-armed, six-rayed forms are assumed to be $D$. variabilis.
Sediments between Samples 598-3-2, 56-57 cm and $598-4-3,56-57 \mathrm{~cm}(17.3$ and $29.0 \mathrm{~m})$ are placed within the $D$. exilis Zone (CN5). The discoaster population consists mainly of $D$. variabilis (abundant), $D$. exilis, $D$. moorei, and $D$. deflandrei (rare). The last occurrence of Cyclicargolithus floridanus is noted within the zone in Sample 598-3-3, 56-57 cm, and it is abundant below that point; its last occurrence approximates the $\mathrm{CN} 5 \mathrm{a} / \mathrm{b}$ subzonal boundary. Specimens of Calcidiscus macintyrei, C. leptoporus, and Reticulofenestra pseudoumbilica, along with Cyclicargolithus floridanus, all of which make up the placolith population, begin to predominate over the discoasters within the lower half of the zone (below approximately $27 \mathrm{~m}$ ) and increase in numbers within older samples.

The last occurrence of $S$. heteromorphus in Sample $598-4-4,56-57 \mathrm{~cm}(30.5 \mathrm{~m})$ places sediments at this depth to basement $(44.8 \mathrm{~m})$ within the $S$. heteromorphus Zone and Helicosphaera ampliaperta Zone (CN4 and 3). The two zones were not delineated because of the absence of 
Table 2. Distribution of calcareous nannofossils in Holes 597A and 597C.

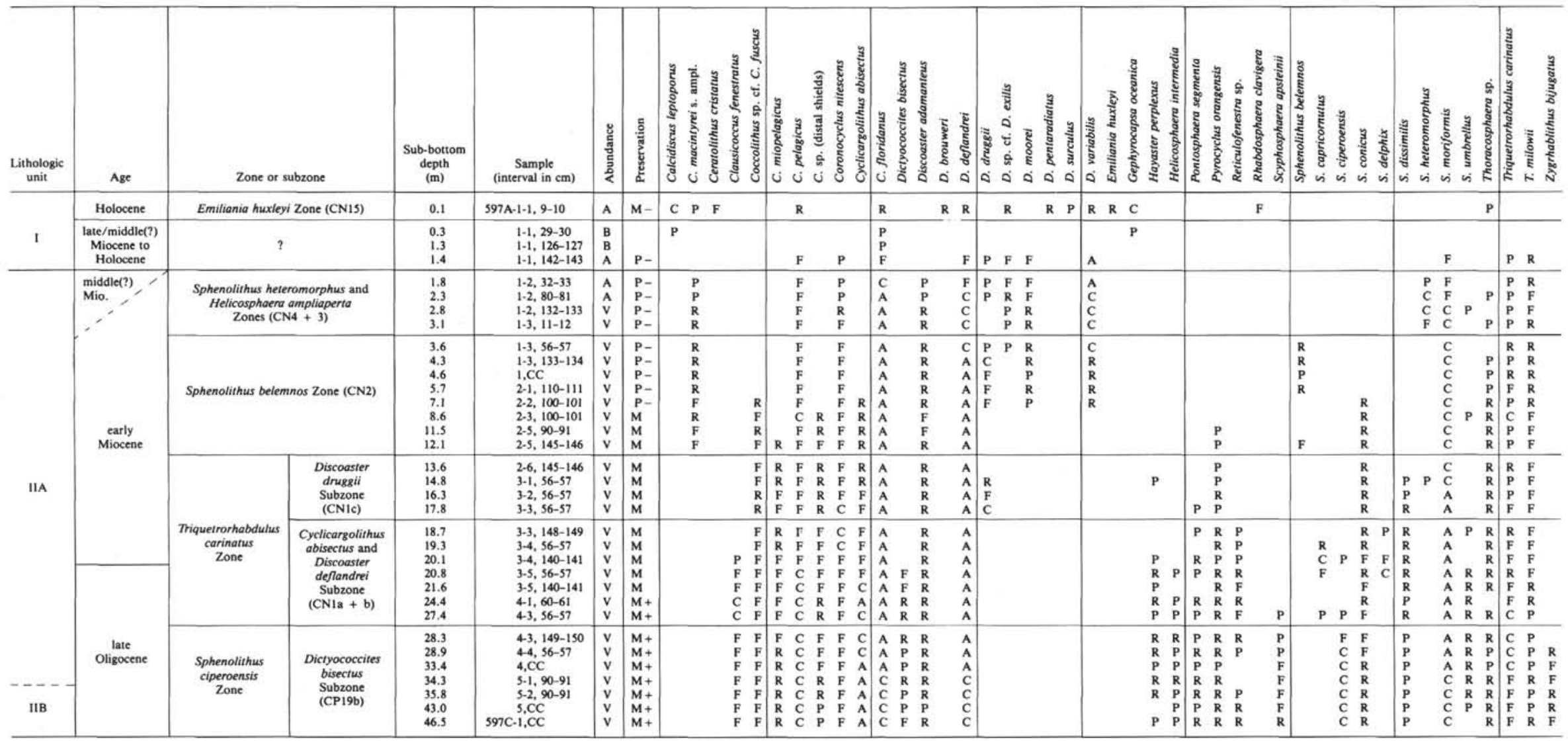

Note: Abundance and preservation as defined in Table 1. 
H. ampliaperta and the gradual reduction of specimens of $D$. deflandrei (as opposed to the termination of its acme). The moderate increase in numbers of $D$. deflandrei from 38.6 to $41.6 \mathrm{~m}$ could, however, be interpreted as the $\mathrm{CN} 4 / 3$ boundary. This corresponds to foraminifer data (Romine, this volume), which place Sections 598$5, \mathrm{CC}$ and 598-6,CC within the early Miocene. The transition from a predominantly fine-rayed discoaster population to a thick-rayed population also corresponds to an increase in secondary calcite overgrowth that is present at the bottom of the hole.

\section{Site 599}

Site 599 is approximately $500 \mathrm{~km}$ east of Site 598 and approximately $3100 \mathrm{~km}$ east of Tahiti (Fig. 1). Sediments recovered range in age from late Miocene to Pleistocene (Table 4) and are located in a broad region of low relief, with abyssal hills ranging from 200 to $300 \mathrm{~m}$ in height. The site was drilled within a small basin where sediment cover was thickest. For the most part, these sediments are probably thin carbonate turbidites (Leinen, Rea, et al., this volume), which appear as alternating zones or bands of light (mostly yellowish brown to dark yellowish brown) and dark (mostly dark reddish brown) color. The zones are from 10 to $100 \mathrm{~cm}$ thick, and the bands are from 2 to $5 \mathrm{~cm}$ thick. The banding is present in Cores 599-2 through 599-4 from 9.5 to $36.7 \mathrm{~m}$ and in Core 599B- 2 between 32.2 and $40.8 \mathrm{~m}$. Nannofossil data indicate a late Miocene age for most of the banded sediments and a significant amount of reworking within the dark-colored layers.

The upper $9.5 \mathrm{~m}$ of sediment show less evidence of reworking. The genus Amaurolithus is present in Sample 599-1-3, 56-57 cm but absent in most sediment examined in and above Sample 599-1-2, 56-57 cm. Sediments above Sample 599-1-2, 56-57 cm (2.1 m) are dated as late early Pliocene (Zone CN11) to Pleistocene. Preservation of nannofossils within the upper $2.1 \mathrm{~m}$ of sediment is generally good; however, some slight signs of etching are present. Different preservational states within the various nannofossils may be caused by the presence of reworked forms. Placoliths show signs of increasing dissolution downhole; discoasters show slight overgrowth with increasing depth.

Samples above 599-1-1, 56-57 cm are questionably placed within the Pleistocene Gephyrocapsa oceanica Zone (CN14). Specimens of $G$. oceanica are present along with other smaller varieties of the genus; however, they are few in number. Various older nannofossils are reworked into the interval. A sedimentary clast at 599-1-1, 7-9 cm contains, for the most part, early Pliocene nannofossils.

Samples 599-1-1, 140-150 cm and 599-1-2, 56-57 cm may represent an interval anywhere from the lower Crenalithus doronicoides Zone (CN13) through the Reticulofenestra pseudoumbilica Zone (CN11). Criteria used for this age determination are the presence of Pseudoemiliania lacunosa in the absence of the genera Amaurolithus and Gephyrocapsa. The first occurrence of $P$. lacunosa closely corresponds with the last occurrence of Amaurolithus spp. at this site as well as at Sites 598,
600 , and 601. Common to abundant specimens of Discoaster brouweri, $D$. pentaradiatus, $D$. tamalis, and $D$. surculus are present within these samples, with additional species that include Ceratolithus cristatus, C. rugosus, $D$. variabilis, $R$. pseudoumbilica, Sphenolithus abies, and $S$. neoabies. $R$. pseudoumbilica is recorded in both samples as well as in the overlying Sample 599-1-1, 56-57 cm; its presence above Sample 599-1-2, 56-57 cm is assumed to be due to reworking.

Sediments from Sample 599-1-3, 56-57 cm (3.6 m) to approximately $12 \mathrm{~m}$ are placed within the lower Pliocene A. tricorniculatus Zone (CN10). Placement of the lower boundary of this zone is somewhat tentative because of the effects of reworking. Specimens from the genus Amaurolithus are fairly common within the lower half of Core 599-1 (down to $7.9 \mathrm{~m}$ ). Triquetrorhabdulus rugosus is present throughout the interval. The very rare occurrence of T. rugosus in Sample 599-1-3, 56-57 cm and the presence of Ceratolithus sp. cf. C. acutus may indicate a condensed upper $\mathrm{CN} 10$ Zone or a missing section between Samples 599-1-3, 56-57 cm and 599-1-2, 56-57 cm.

Nannofossil preservation is moderate throughout most of the cored interval below $3.6 \mathrm{~m}$, and many of the finer nannolith structures are obscured. Positive identification of $D$. quinqueramus and $D$. berggrenii is hampered by the lack of a clearly visible stellate knob in most forms observed. Identification of $D$. neohamatus is also questionable, because most individuals lack a consistent, well defined twist of the ray tips and are therefore difficult to distinguish from other fine, six-rayed discoasters, especially $D$. braarudii. Poorly preserved forms of $D$. surculus and A. primus are, however, easy to identify. The first occurrence of these two species is somewhat questionable below $9.5 \mathrm{~m}$ because of the reworking present, and exact zonal assignment is difficult.

The first occurrence of A. primus is found in Sample 599-4-3, 56-57 cm, which places sediment between Samples 599-2-3, 137-138 cm (12.3 m) and 599-4-3, 56-57 $\mathrm{cm}(30.7 \mathrm{~m})$ within the uppermost Miocene A. primus Subzone (CN9b). The upper boundary of this subzone, which is defined by the last occurrence of $D$. quinqueramus, is placed at $12.3 \mathrm{~m}$ because Sample 599-2-2, 137$138 \mathrm{~cm}$ is the last consistent occurrence of $D$. quinqueramus within a light-colored sediment. The occurrence of $D$. quinqueramus above that point is assumed to be the result of reworking. Individuals of $A$. primus below $25 \mathrm{~m}$ are primarily heavily overgrown by secondary calcite. These forms are similar to those illustrated by Bukry and Percival (1971, pl. 1, figs. 12 and 13) and by Gartner and Bukry (1975, figs. $7 \mathrm{~g}$, i).

Of particular interest is the out-of-order occurrence of several nannofossil species within the A. primus Subzone. These occurrences are especially frequent in Section 599-3-3 (Samples 599-3-3, 18-19 cm and 599-3-3, 21-22 cm). Sample 599-3-3, 21-22 cm was taken from a light-colored layer and was found to contain specimens of $A$. primus and $D$. surculus. This light-colored layer was found directly below a dark-colored layer; the contact between the two was sharp. The dark-colored layer did not contain the two nannofossils mentioned above; however, D. neohamatus and Minylitha convallis, which 
Table 3. Distribution of calcareous nannofossils in Hole 598.

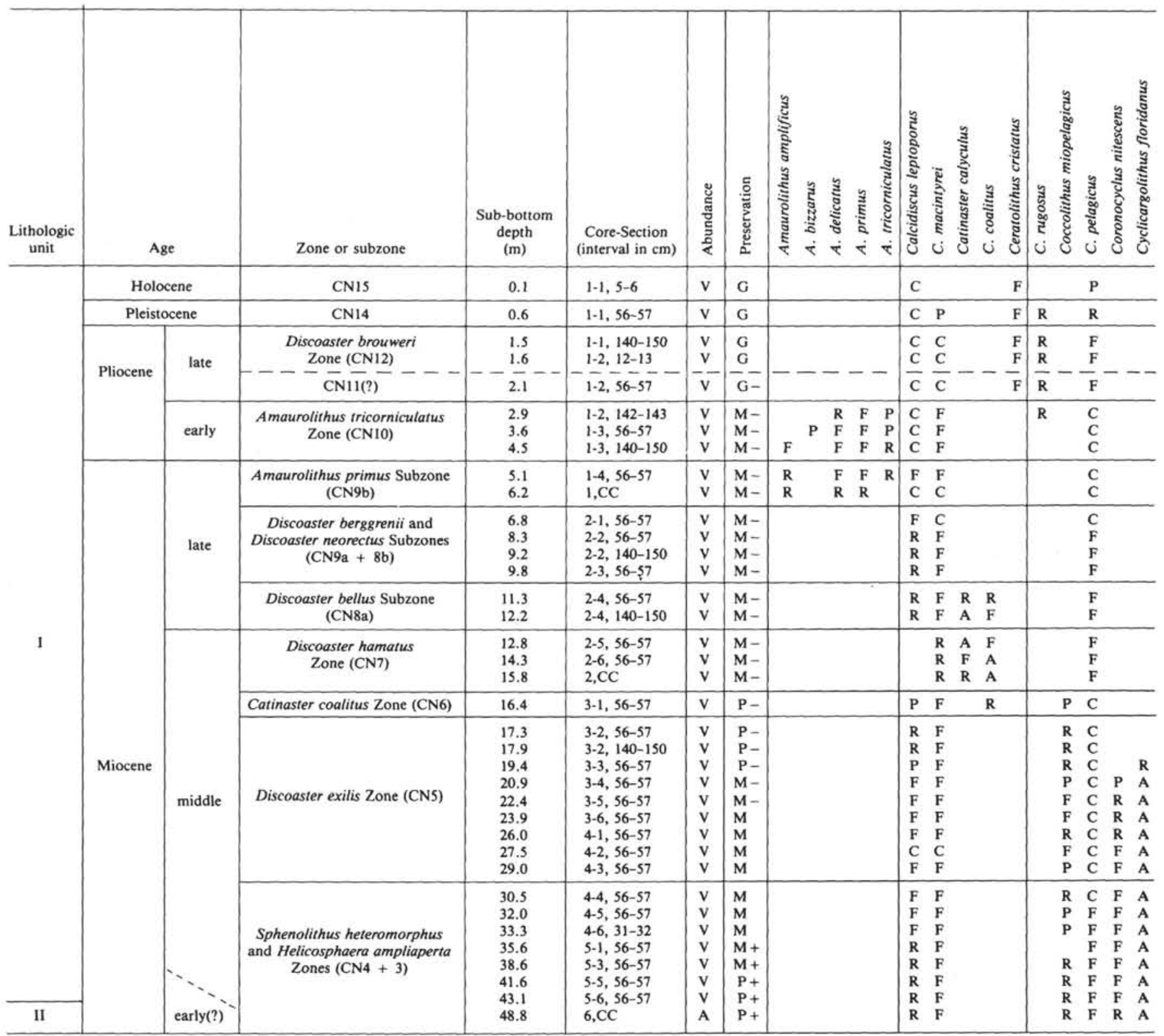

Note: Abundance and preservation as defined in Table 1; G = good.

represent an older nannofossil assemblage, were present. This inverted stratigraphic relationship, indicating turbidite activity, is discussed further later in this report (see Evidence for Downslope Transport of Sediment on the East Pacific Rise, Site 599).

Sediments between Samples 599-4-3, 92-93 cm (31.0 $\mathrm{m})$ and $599-4-5,127-128 \mathrm{~cm}(34.4 \mathrm{~m})$ are placed within the $D$. berggrenii Subzone (CN9a). The absence of $A$. primus and the presence of both $D$. surculus and $D$. berggrenii define the zone. Positive identification of $D$. berggrenii was difficult, because most forms are moderately overgrown. D. surculus is rare in most samples examined from this interval. The absence of $A$. primus below $31.0 \mathrm{~m}$ within Hole 599, however, is somewhat questionable. Although no specimens of $A$. primus are found below Sample 599-4-3, 56-57 cm (30.7 m), they do oc- cur, although they are rare, within Sample 599B-2-3, 56$57 \mathrm{~cm}(35.8 \mathrm{~m})$. The latter sample occurs within a lightcolored layer and is the only sample examined from Hole 599B that contains $A$. primus. Specimens of $D$. surculus are also common in that sample. If it is assumed that Sample 599B-2-3, 56-57 cm occurs stratigraphically below Sample $599-4-3,56-57 \mathrm{~cm}$, as is indicated by its subbottom depth ( $35.8 \mathrm{~m}$ versus $30.7 \mathrm{~m}$ ), then all sediments above Section 599-4,CC must be contained within the A. primus Subzone. This situation would be similar to that observed in sediments from Section 599-3-3. The common occurrence of $D$. surculus, however, suggests that the Sample 599B-2-3, 56-57 cm correlates with sediment higher in Hole 599. This rationale is supported by the less heavily calcified $A$. primus in this horizon. The possibility of downhole contamination must be consid- 
Table 3 (continued).

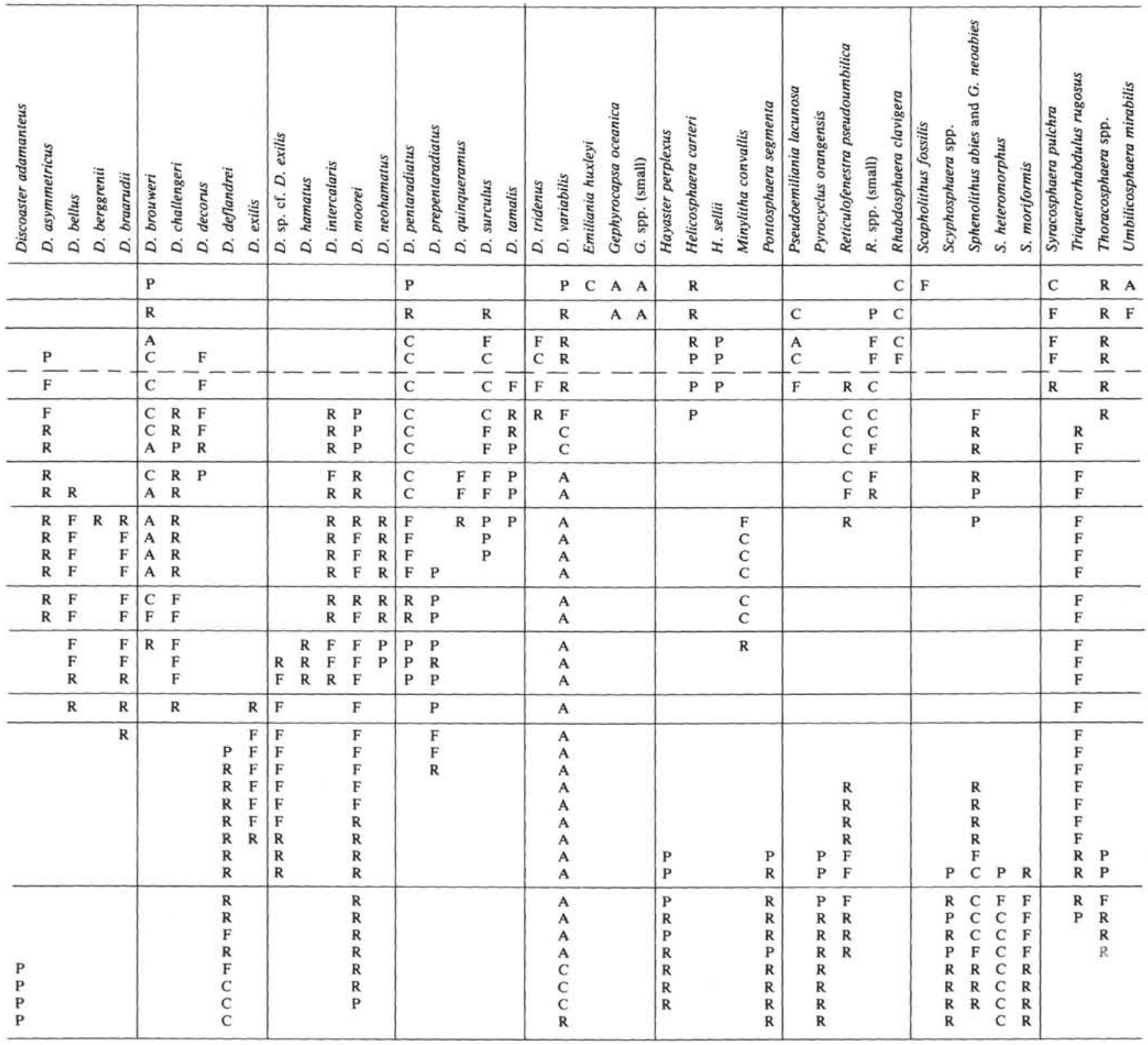

ered, because specimens of $A$. delicatus are observed and very rare individuals of $C$. cristatus are present. The fine fraction of Section 599B-3,CC which is a core of "drilling breccia," is also found to contain a mixed assemblage of Pleistocene to late Miocene nannofossils.

The oldest sediments recovered at Site 599 (from Samples 599-4-6, 56-57 cm [35.2 m] and 599B-2-4, 56-57 cm [37.3 m] down to basement) are assigned to the upper subzone of the $D$. neohamatus Zone, $D$. neorectus Subzone (CN8b). The absence of Discoaster surculus in the presence of $D$. neohamatus and $M$. convallis is used to define the zone. Preservation is moderate to poor, with most discoasters showing moderate overgrowth.

\section{Sites 600 to 602}

Sites 600 through 602 are approximately $310 \mathrm{~km}$ east of Site 599 and are the sites nearest to the East Pacific
Rise of the six cored on Leg 92 (Fig. 1). Because of the close proximity of these sites and their similar lithology, they are discussed together. From the 10 holes cored at these three sites, eight recovered sediment, but only two, Holes $600 \mathrm{C}$ and 601 , contain enough sediment for adequate biostratigraphic interpretation (Table 5).

Holes 600 and 600B yielded respectively $5.4 \mathrm{~m}$ and $1.9 \mathrm{~m}$ of late Pliocene to Pleistocene sediment. All samples examined from these cores contain abundant discoasters characteristic of the lower Discoaster brouweri Zone (CN12); however, rare specimens of Gephyrocapsa spp. are observed.

The $5.8 \mathrm{~m}$ of sediment recovered from Hole 601B are dated as early Pliocene. These sediments contain nannofossils similar to those found in the bottom of Hole 601 and are discussed along with Hole 601 .

Two of the three holes cored at Site 602 were examined for their nannofossil content. The $6.2 \mathrm{~m}$ of washed 
Table 4. Distribution of calcareous nannofossils in Hole 599.

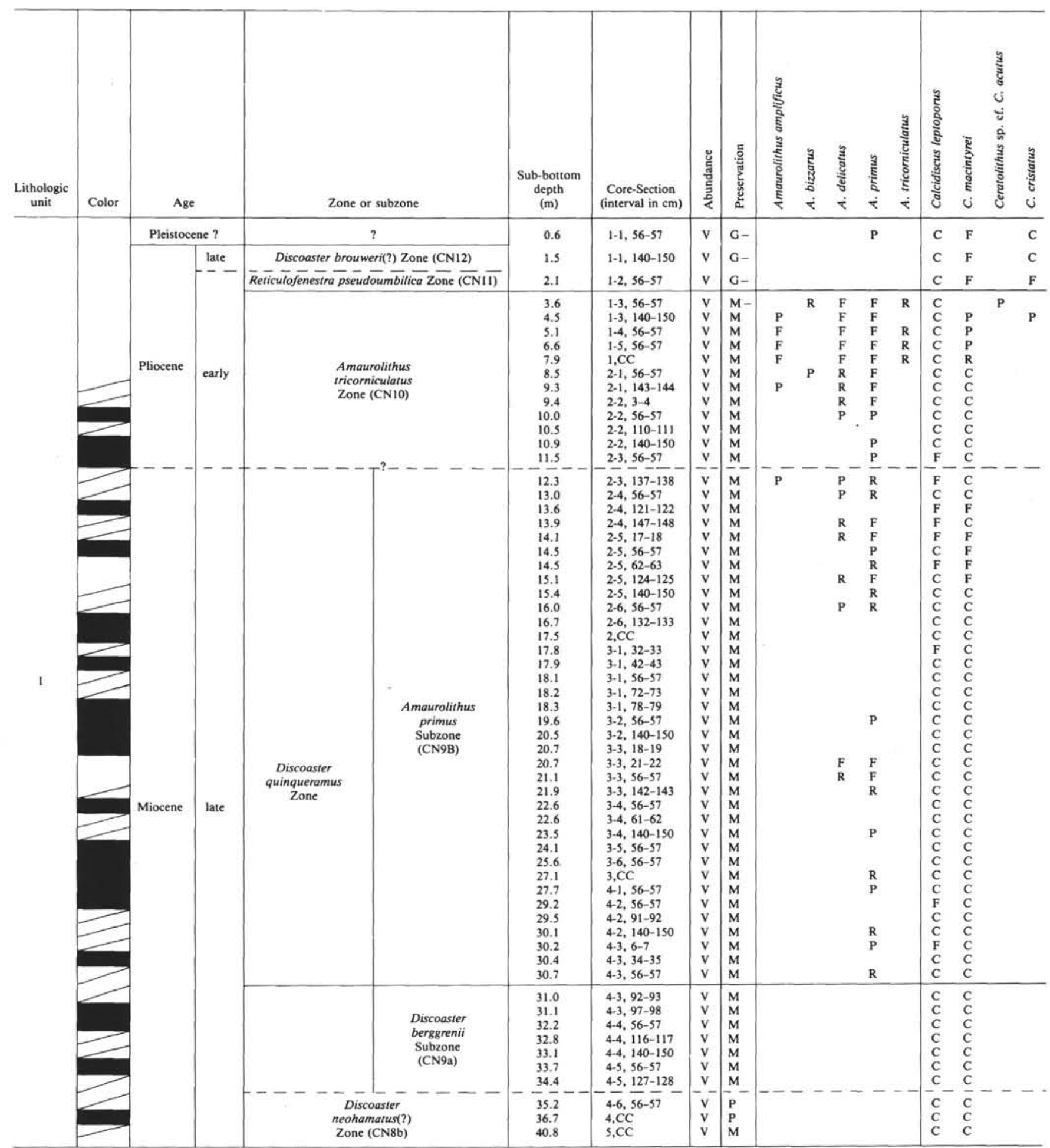

Note: Abundance and preservation as defined in Table 3. Colors as defined in Figure 5.

sediment recovered from Hole 602 were not examined in any detail. Holes $602 \mathrm{~A}$ and $602 \mathrm{~B}$ yielded $2.28 \mathrm{~m}$ and $4.24 \mathrm{~m}$ of Pleistocene sediment, respectively. Inadvertently, Hole 602B was probably repeatedly cored. Rock chips at four different depths suggest that repeated sec- tions were cored because of the ship's motion after the hydraulic piston corer jammed during recovery operations. Nannofossils in dark-colored sediment above these horizons show similar amounts of early Pliocene nannofossils. Light-colored sediment, which contains fewer 
Table 4 (continued).

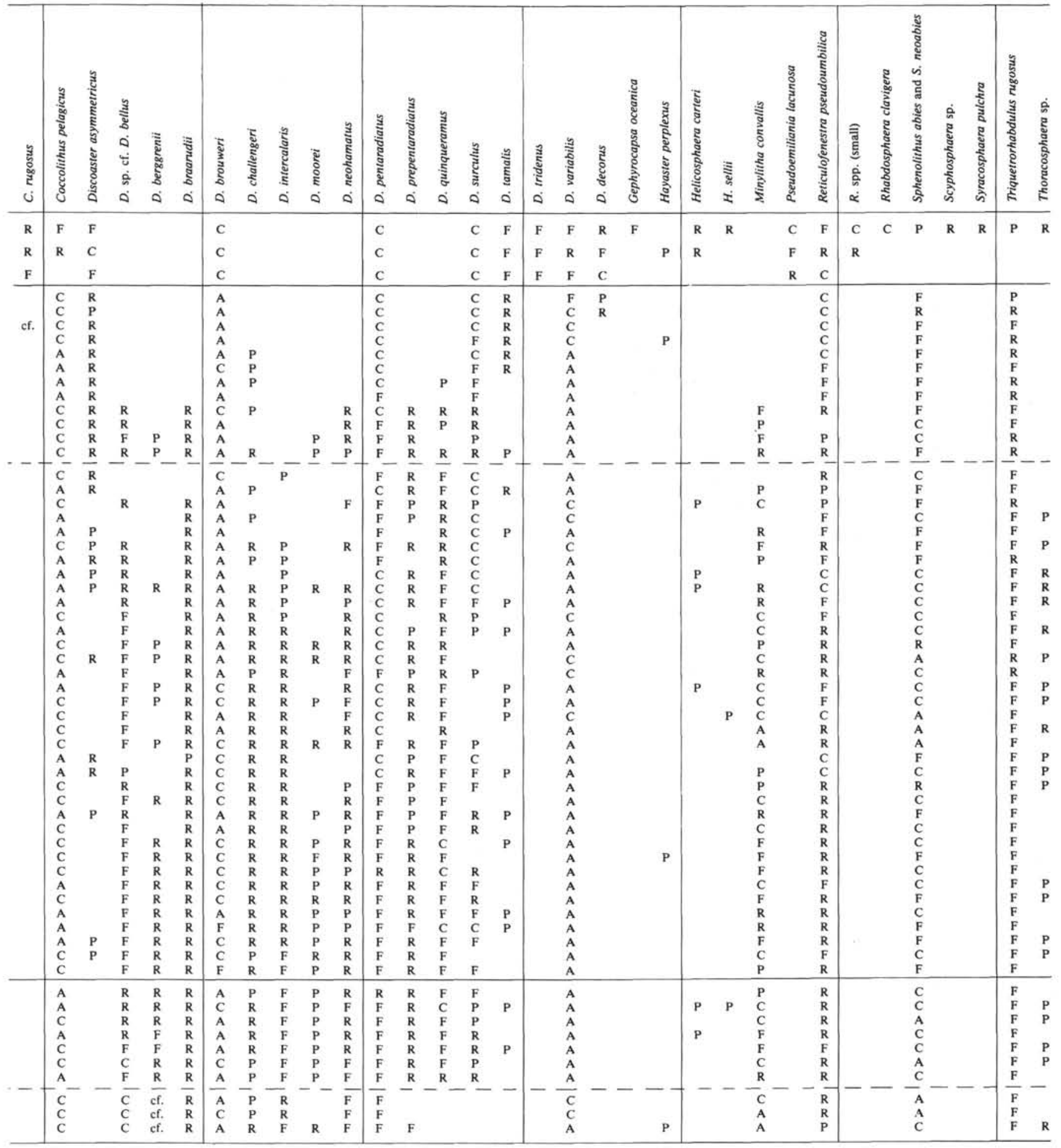

Pliocene species and numerous Pleistocene nannofossils, is found above the dark-colored sediment and the layers of rock chips.

Sediment from Holes $600 \mathrm{C}$ and 601 is dated as early Pliocene to Pleistocene. The Pliocene/Pleistocene boundary is placed at the extinction of Calcidiscus macintyrei (Backman et al., 1983), which occurs between
Samples $600 \mathrm{C}-1-2,56-57 \mathrm{~cm}$ and $600 \mathrm{C}-1-3,56-57 \mathrm{~cm}$ $(2.1$ and $3.6 \mathrm{~m})$ in Hole $600 \mathrm{C}$. The Pleistocene in Hole 601 is not recognizable by nannofossils, inasmuch as abundant discoasters are present in all samples examined and Gephyrocapsa spp. were not observed; this would indicate a late Pliocene age, Discoaster brouweri Zone (CN12). Foraminiferal data, however, indicate an 
Table 5. Distribution of calcareous nannofossils in Holes $600 \mathrm{C}$ and 601.

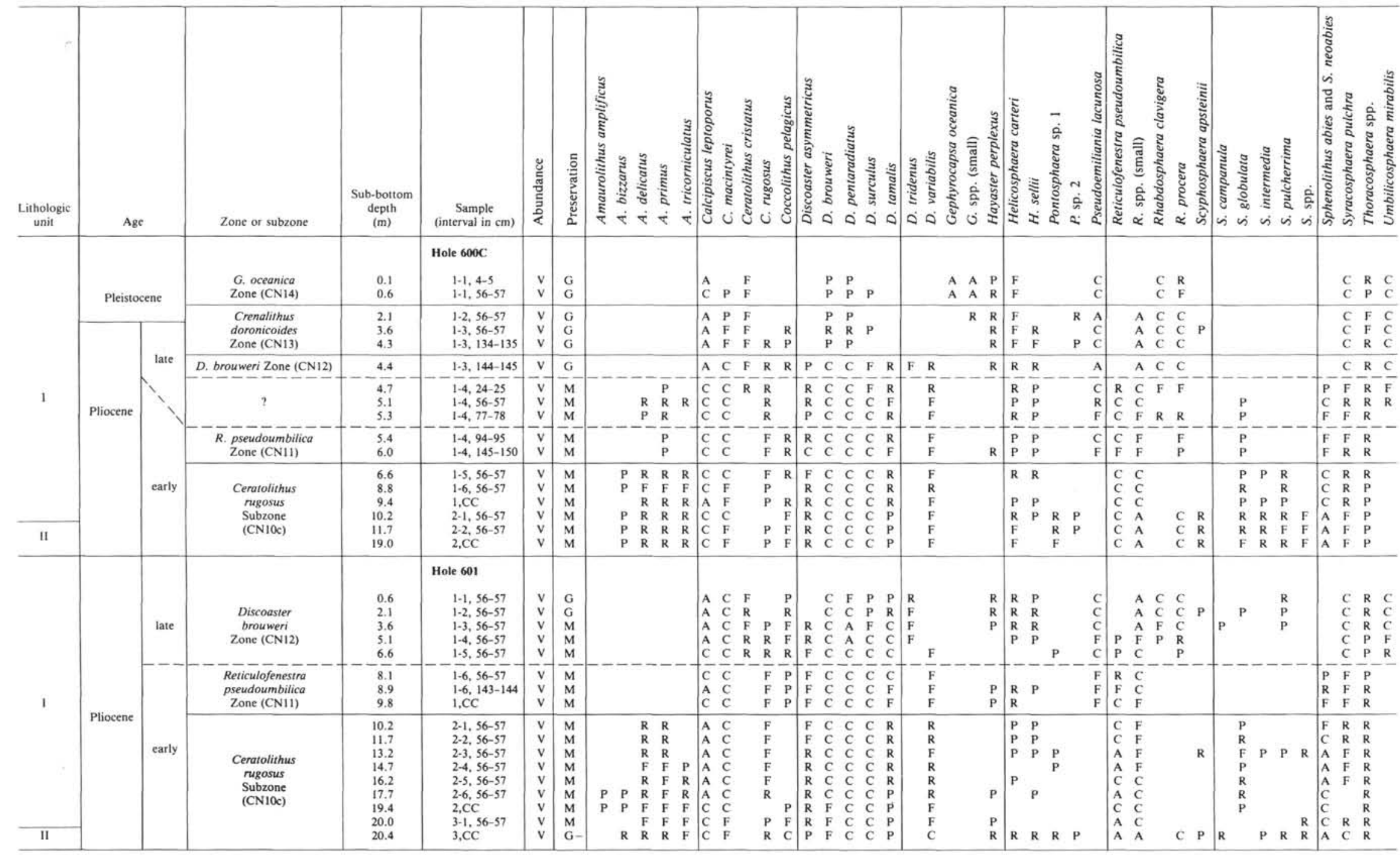

Note: Abundance and preservation as defined in Table 3. 
early Pleistocene age (Romine, this volume) for sediment in and above Sample 601-1-2, 140-150 cm; Globorotalia truncatulinoides is present.

Sediments in and above Sample 600C-1-1, 56-57 cm $(0.6 \mathrm{~m})$ in Hole $600 \mathrm{C}$ are placed within the Gephyrocapsa oceanica Zone (CN14). Specimens of G. oceanica are abundant, and Emiliania huxleyi is absent.

Samples 600C-1-2, 56-57 cm through 600C-1-3, 134$135 \mathrm{~cm}$ are contained within the Crenalithus doronicoides Zone (CN13). Only rare, reworked discoasters are present, and G. oceanica is absent. Calcidiscus macintyrei has its last appearance in this zone.

The late Pliocene $D$. brouweri Zone (CN12) is poorly represented within Holes $600 \mathrm{C}$ and 601 , and this zonal assignment is somewhat questionable. Only one sample in Hole $600 \mathrm{C}(600 \mathrm{C}-1-3,144-145 \mathrm{~cm})$ seems to clearly indicate its presence. Discoasters have their last occurrence in this sample and show a clear reduction in numbers between this sample and the overlying one. Common well preserved $D$. brouweri and $D$. pentaradiatus are observed in Sample 600C-1-3, 144-145 cm. The paucity of reworked early Pliocene forms suggests deposition without significant reworking in the upper $D$. brouweri Zone (CN12c or d). Sediments from Sample 600C$1-4,24-25 \mathrm{~cm}(4.7 \mathrm{~m})$ to $5.32 \mathrm{~m}$ in Hole $600 \mathrm{C}$, where a sharp sedimentary contact is seen, and the upper $6.6 \mathrm{~m}$ of Hole 601 are of indefinite age. The interval in Hole $600 \mathrm{C}$ ( $4.7 \mathrm{~m}$ to $5.3 \mathrm{~m}$ ) contains Amaurolithus spp., which are probably reworked, and suggests that sediment above a lithologic contact at the base of this interval $(600 \mathrm{C}$ $1-4,82 \mathrm{~cm}$ ) has been redeposited. A sharp contact is not visible in Hole 601. The gradual change in sediment color, however, from light brown to dark brown, and a corresponding change in nannofossil content can be correlated with Hole $600 \mathrm{C}$. The light brown sediment above Sample $601-1-5,56-57 \mathrm{~cm}(6.6 \mathrm{~m})$ in Hole 601 is placed within the $D$. brouweri Zone (CN12). Discoasters are slightly overgrown within the lower $3 \mathrm{~m}(3.6$ to $6.6 \mathrm{~m})$, and rare Reticulofenestra pseudoumbilica in Samples 601$1-4,56-57 \mathrm{~cm}$ and $601-1-5,56-57 \mathrm{~cm}$ are presumed reworked. A change in nannofossil preservation from good to moderate occurs in Hole $600 \mathrm{C}$ at approximately $4.6 \mathrm{~m}$ and in Hole 601 at approximately $2.8 \mathrm{~m}$.

The $R$. pseudoumbilica Zone (CN11) is recognized in Hole $600 \mathrm{C}$ below the sediment contact at $5.32 \mathrm{~m}$ to Sample $600 \mathrm{C}-1-4,145-150 \mathrm{~cm}(6.0 \mathrm{~m})$ and in Hole 601 between Sample 601-1-6, 56-57 cm and Section 601-1,CC ( 8.1 and $9.8 \mathrm{~m})$. Both $R$. pseudoumbilica and Sphenolithus spp. are present, and Amaurolithus tricorniculatus is absent. The first occurrence of Pseudoemiliania lacunosa is also noted at the bottom of the zone.

Sediments from and below Samples 600C-1-5, 56$57 \mathrm{~cm}$ and 601-2-1, 56-57 cm and all those from Hole $601 \mathrm{~B}$ are contained within the $A$. tricorniculatus Zone, Ceratolithus rugosus Subzone (CN10c). The overlapping ranges of Amaurolithus spp. and C. rugosus are used to define the subzone. The last occurrence of $A$. tricorniculatus is noted slightly lower than $A$. primus and $A$. delicatus in Hole 601. The last occurrences of $A$. primus and $A$. delicatus are used to mark the $\mathrm{CN} 10 / \mathrm{CN} 11$ boundary, because the extinction of these two species closely correlates with the first occurrence of $P$. lacuno$s a$, as at Sites 598 and 599. The modest increase in numbers of $D$. asymmetricus between the last occurrence of A. tricorniculatus and the last occurrence of $A$. delicatus and $A$. primus suggests a correlation with the $A$. delicatus Subzone (CN10d) of Bukry (1981).

Nannofossil preservation is moderate throughout most of the early Pliocene section at these sites. Discoasters are overgrown and placoliths are etched. Only Section 601-3,CC shows better preservation. Although some overgrowth is evident on most forms, preservation is better than in the samples above; however, it is not as good as that from the tops of the holes.

\section{Eltanin Cores}

Nannofossils were examined from several U.S.N.S. Eltanin cores south and southeast of the Leg 92 transect (Fig. 1) in order to give a more comprehensive sample of biostratigraphic data along the East Pacific Rise. These cores also provided supplementary data to parts of the column that were condensed and/or missing in the Leg 92 sites.

Fourteen piston cores from three cruises of the U.S.N.S. Eltanin (Cruises 21, 24, and 25; Table 6) were examined for calcareous nannofossils (Tables 7 to 9). Of these, seven cores (E21-1, -2, -3, -5, -11, -12, and E2416) contain nannofossil assemblages similar to those at the Leg 92 sites; two cores (E24-9 and -10) contain nannofossils that are older; and one core (E25-2) contains early Pliocene or late Miocene nannofossils that are probably a cooler water assemblage. The remaining four cores (E24-11, -13, -14, and E25-1) are essentially barren of calcareous nannofossils, with only rare Miocene forms present within the bioturbated intervals.

Cores E24-9 (below $442 \mathrm{~cm}$; above which sediments are barren of nannofossils) and E24-10 contain a poorly preserved assemblage that is tentatively dated as middle Eocene (Reticulofenestra umbilica Zone, CP14). Specimens of Chiasmolithus altus, C. expanus, Coccolithus eopelagicus, C. formosus, Discoaster sp. cf. D. deflandrei, and Reticulofenestra umbilica form the majority of the assemblage. The apparent absence of $D$. barbadi-

Table 6. U.S.N.S. Eltanin piston core station location data for cores used in this study.

\begin{tabular}{lcccc}
\hline Core & Latitude (S) & Longitude (W) & $\begin{array}{c}\text { Water } \\
\text { depth (m) }\end{array}$ & $\begin{array}{c}\text { Core } \\
\text { length (cm) }\end{array}$ \\
\hline E21-1 & $33^{\circ} 03^{\prime}$ & $83^{\circ} 59^{\prime}$ & 3630 & 350 \\
E21-2 & $32^{\circ} 59^{\prime}$ & $87^{\circ} 57.5^{\prime}$ & 3658 & 445 \\
E21-3 & $34^{\circ} 57^{\prime}$ & $91^{\circ} 57.5^{\prime}$ & 3621 & 508 \\
E21-5 & $36^{\circ} 41^{\prime}$ & $93^{\circ} 38^{\prime}$ & 3136 & 480 \\
E21-11 & $39^{\circ} 58^{\prime}$ & $112^{\circ} 09^{\prime}$ & 2798 & 609 \\
E21-12 & $40^{\circ} 21^{\prime}$ & $119^{\circ} 35^{\prime}$ & 4151 & $155^{\text {a }}$ \\
E24-9 & $40^{\circ} 35^{\prime}$ & $135^{\circ} 16^{\prime}$ & 4837 & 624 \\
E24-10 & $37^{\circ} 58^{\prime}$ & $134^{\circ} 59^{\prime}$ & 4874 & 361 \\
E24-11 & $40^{\circ} 01^{\prime}$ & $132^{\circ} 35^{\prime}$ & 4874 & 481 \\
E24-13 & $39^{\circ} 37^{\prime}$ & $130^{\circ} 11^{\prime}$ & 4759 & 979 \\
E24-14 & $39^{\circ} 32^{\prime}$ & $127^{\circ} 26^{\prime}$ & 4466 & 1304 \\
E24-16 & $35^{\circ} 13^{\prime}$ & $124^{\circ} 59^{\prime}$ & 3932 & 1169 \\
E25-1 & $36^{\circ} 38^{\prime}$ & $83^{\circ} 15^{\prime}$ & 4007 & 1087 \\
E25-2 & $39^{\circ} 56^{\prime}$ & $85^{\circ} 55^{\prime}$ & 3877 & 535 \\
\hline
\end{tabular}

a Listed as $142 \mathrm{~cm}$ in Goodell (1968). 
Table 7. Calcareous nannofossil zones, abundances, and preservation from U.S.N.S. Eltanin cores (other than E21-2 and E24-16) within the study area. Lithologic descriptions of these cores can be found in Goodell (1968).

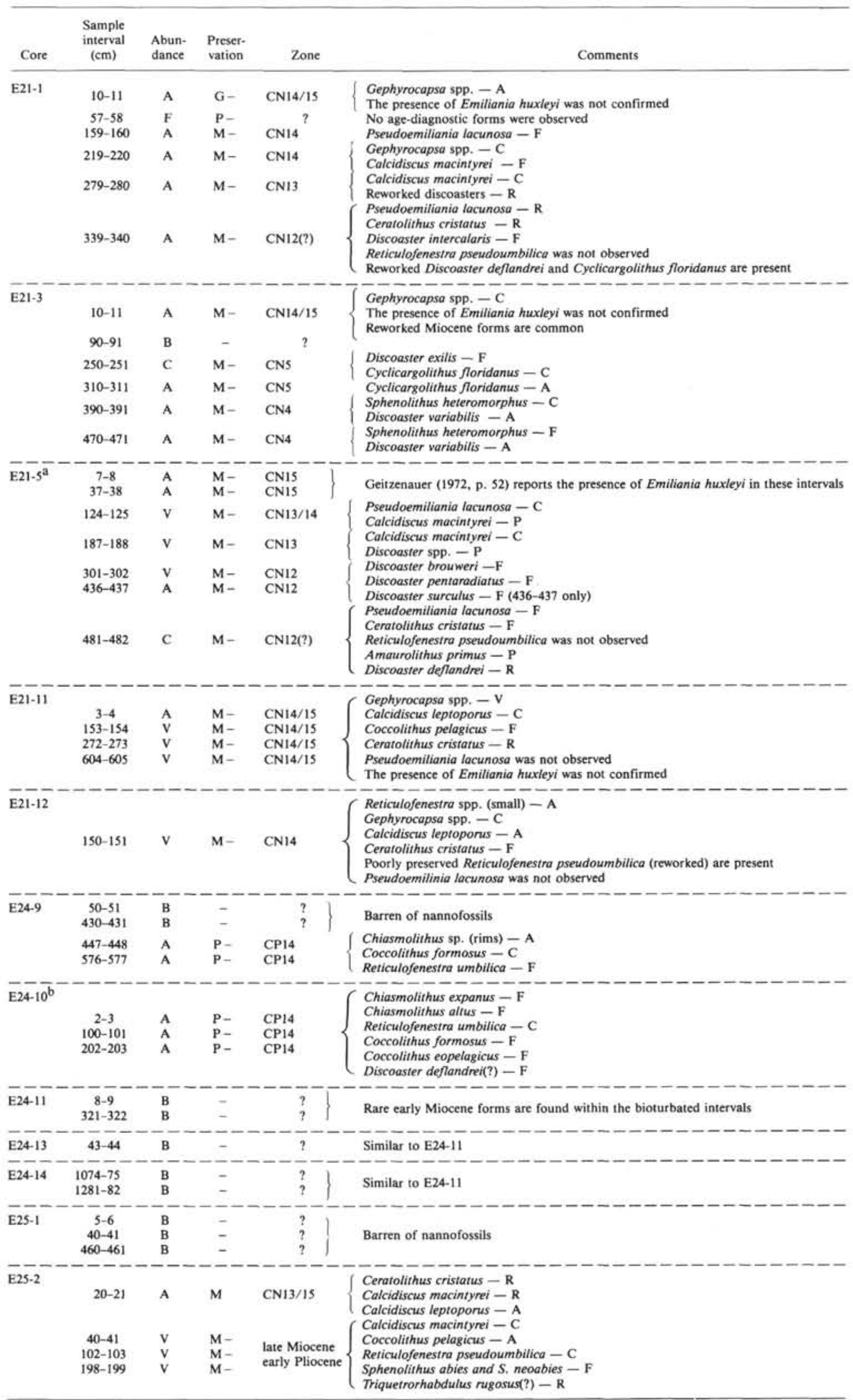

Note: Abundance and preservation as defined in Table 3.

a Detailed data on the abundances of various other nannofossils species are found in Geitzenauer (1972).

$b$ Preservation is slightly better in this core than in Core E24-9. 
ensis and D. saipanensis would seem to indicate an early Oligocene age (Helicosphaera reticulata Zone, CP16a and b). Foraminifer data, however, support a middle Eocene age (Toker, pers. comm., 1984). Specimens of Globigerinatheka kugleri and $G$. index are present.

Four of the cores studied from Cruise E21 (E21-1, $-5,-11$, and -12) contain Pleistocene material. Two of these (E21-1 and -5) also contain upper Pliocene sediment. Cores E21-11 and E21-12, 609 and $155 \mathrm{~cm}$ long (listed as $142 \mathrm{~cm}$ in Goodell, 1968), respectively, are all placed within the Gephyrocapsa oceanica Zone (CN14). The presence of Emiliania huxleyi was not confirmed, however, because no scanning electron microscope was available at the time.

Specimens of $G$. oceanica are also present in Core E21-1 down to $220 \mathrm{~cm}$, below which (Sample E21-1, 279$280 \mathrm{~cm}$ ) Calcidiscus macintyrei is common. The Pliocene/Pleistocene boundary, therefore, is placed between 220 and $279 \mathrm{~cm}$ in Core E21-1. Only rare reworked discoasters are present within Sample E21-1, 279-280 cm, and the sample is placed within the Crenalithus doronicoides Zone (CN13). D. brouweri, $D$. pentaradiatus, $D$. surculus, and rare $D$. deflandrei are present within Sample E21-1, 339-340 cm; Ceratolithus cristatus and Pseudoemiliania lacunosa are also present. These species are characteristic of the $D$. brouweri Zone (CN12) except for $D$. deflandrei, which is reworked.

Core 21-5 was previously studied by Kennett and Geitzenauer (1969) and Geitzenauer (1972), who give detailed information on the microfossil assemblages. Geitzenauer (1972), however, only briefly mentioned the presence of Calcidiscus macintyrei. Specimens of C. macintyrei are few to common within Sample E21-5, 187-188 cm, but they are essentially absent in Sample E21-5, 124$125 \mathrm{~cm}$. This extinction is used to approximate the Pliocene/Pleistocene boundary. The broken nature of discoasters in sediment between $180 \mathrm{~cm}$ and down to approximately $300 \mathrm{~cm}$ suggests that they may be reworked. The decrease in the numbers of discoasters above approximately $300 \mathrm{~cm}$ (see Geitzenauer, 1972, p. 53) is considered sufficient evidence for placing the discoaster extinction at this level. Discoasters below a sediment contact at $336 \mathrm{~cm}$ are slightly more overgrown than those above. This, along with the rare occurrence of reworked species, which include Amaurolithus primus and D. deflandrei, suggests a situation similar to that found in DSDP Hole $600 \mathrm{C}$, where sediment from the upper $D$. brouweri Zone overlies a reworked interval.

Lower and middle Miocene sediment within Cores E21-2 (Table 8), E21-3, and E24-16 (Table 9) represents Zones CN2 through CN5. The Sphenolithus belemnos Zone (CN2) is determined for Cores E21-2 and E24-16 from 384 to $445 \mathrm{~cm}$ and 136 to $420 \mathrm{~cm}$, respectively. $S$. belemnos is rare to few in abundance within this interval. Specimens of Cyclicargolithus floridanus and $D$. deflandrei are the most dominant forms; Calcidiscus macintyrei and $D$. druggii are also present. The $H$. ampliaperta Zone and $S$. heteromorphus Zone $(\mathrm{CN} 3$ and 4$)$ are represented in all three of these cores: from 254 to 336 $\mathrm{cm}$ in E21-2; from 390 to $508 \mathrm{~cm}$ in E21-3; and from 18 to $96 \mathrm{~cm}$ in E24-16. Specimens of $S$. heteromorphus are few to common in all samples. These two zones could only be delineated in Core E21-2, where the termination of the $D$. deflandrei acme was clearly visible. $D$. deflandrei is abundant in Sample E21-2, 335-336 cm, and $D$. variabilis is the most dominant discoaster in and above Sample E21-2, 293-294 cm. Because of the observations in Core E21-2, the interval in E21-3 from 390 to $508 \mathrm{~cm}$ is placed within the CN4 Zone (D. variabilis is abundant). The interval in E24-16 from 18 to $96 \mathrm{~cm}$ also probably represents Zone $\mathrm{CN} 3$; however, the compressed nature of the section makes it difficult to determine. The $D$. exilis Zone (CN5) is only present in E21-3 between 250 and $311 \mathrm{~cm}$. Specimens of $D$. exilis are present, and $S$. heteromorphus is absent. D. variabilis and Cyclicargolithus floridanus are the most dominant forms present. All three cores (E21-2, -3, and E24-16) have a thin layer of Pleistocene sediment at their tops. The intervals in Cores E21-2 and E21-3, below the Pleistocene layers down to approximately $2.3 \mathrm{~m}$, are essentially barren of nannofossils.

The remaining core, E25-2, is distinctly different from the other cores studied. The nannofossil assemblage in and below $40 \mathrm{~cm}$ is dominated by placoliths, particularly Calcidiscus leptoporus, C. macintyrei, Coccolithus pelagicus, and $R$. pseudoumbilica. Discoasters make up only a small percentage of the assemblage, and they are poorly preserved. Specimens of $S$. abies, S. neoabies, and Triquetrorhabdulus rugosus are also observed. The presence of $T$. rugosus indicates a minimum age of early Pliocene (Zone $\mathrm{CN} 10 \mathrm{a}$ ) and a maximum age limit of middle Miocene (CN4). The location of this core below the present subtropical convergence (Deacon, 1963; Garner, 1954) and the high Coccolithus/Discoaster ratio (Bukry, 1981; McIntyre et al., 1970) suggest a cooler water nannofossil assemblage.

\section{EVIDENCE FOR DOWNSLOPE TRANSPORT OF SEDIMENT ON THE EAST PACIFIC RISE, SITE 599}

Shipboard investigation of nannofossils from Site 599 presented an interesting problem for biostratigraphic zonation. Samples routinely taken from the $56-57 \mathrm{~cm}$ interval were found almost entirely within dark-colored sediments. Upon examination, samples between 10.0 and $25.5 \mathrm{~m}$ were originally thought to occur below the CN9b/ 9a boundary because of the apparent absence of Amaurolithus primus and the presence of Discoaster neohamatus and Minylitha convallis. These two species were not found above the first occurrence of $A$. primus at Site 598. Specimens of $A$. primus are, however, found in Sample 599-3-3, 21-22 cm. This sample was taken from a light brown layer that forms a sharp contact with the overlying dark brown layer. D. neohamatus and Minylitha convallis are not found within Sample 599-3-3, 21$22 \mathrm{~cm}$; however, they are present within the overlying dark-colored layer (Sample 599-3-3, 18-19 cm). The occurrences of $D$. neohamatus and $M$. convallis are normally restricted to the CN8 Zone and CN9a Subzone, which suggests that their presence within the dark-colored sediment above may be due to post-depositional reworking and/or transport. 


\section{S. KNÜTTEL}

Table 8. Distribution of calcareous nannofossils in Core E21-2. A lithologic description of this core can be found in Goodell (1968).

\begin{tabular}{|c|c|c|c|c|c|c|c|c|c|c|c|c|c|c|c|c|c|c|c|c|c|c|c|c|c|}
\hline $\begin{array}{l}\text { Lithologic } \\
\text { unit }\end{array}$ & \multicolumn{2}{|c|}{ Age } & Zone & $\begin{array}{c}\text { Sample } \\
\text { (interval in } \mathrm{cm} \text { ) }\end{array}$ & 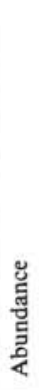 & 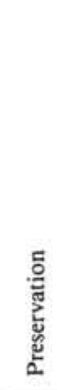 & . & $\begin{array}{l}0 \\
0 \\
0 \\
0 \\
0 \\
0 \\
0 \\
0\end{array}$ & 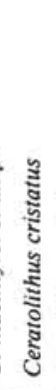 & 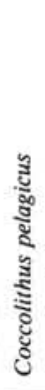 & 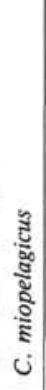 & 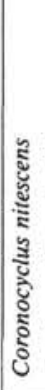 & 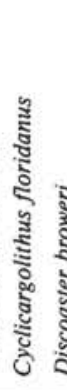 & 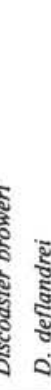 & 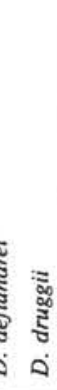 & ڤั & $\begin{array}{l} \\
\vdots \\
0 \\
0 \\
0 \\
0 \\
0\end{array}$ & 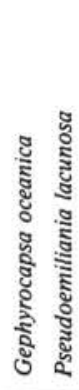 & 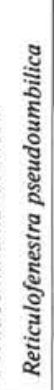 & 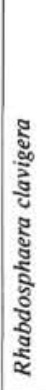 & 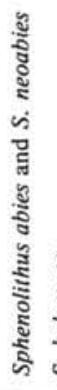 & 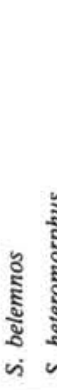 & 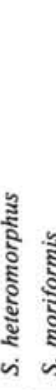 & 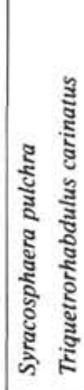 & है \\
\hline \multirow{2}{*}{ I } & \multicolumn{2}{|c|}{ Pleistocene } & CN14(?) & $17-18$ & A & $\mathrm{M}-$ & c & $=R$ & $F$ & $\mathrm{~F}$ & & & $F \quad F$ & $F \quad F$ & & & $R$ & C $\mathrm{F}$ & R & C & $\mathrm{R}$ & & & F & \\
\hline & \multicolumn{2}{|c|}{$?$} & $?$ & 198-199 & $\mathbf{R}$ & $\mathrm{P}-$ & & & & & & & $\mathrm{R} \mathrm{R}$ & $R \quad R$ & & & $\mathrm{P}$ & & & & & & & & \\
\hline \multirow{3}{*}{ II } & \multirow{3}{*}{ Miocene } & \multirow{3}{*}{ middle } & $\mathrm{CN} 4$ & $\begin{array}{l}254-255 \\
293-294\end{array}$ & $\begin{array}{l}\mathrm{v} \\
\mathrm{v}\end{array}$ & $\begin{array}{l}\mathrm{M} \\
\mathrm{M}\end{array}$ & I & $\begin{array}{l}F \\
R\end{array}$ & & $\begin{array}{l}\mathrm{F} \\
\mathrm{F}\end{array}$ & & $\mathrm{F}$ & $\begin{array}{l}\text { A } \\
\text { A }\end{array}$ & $\begin{array}{l}\text { C } \\
\text { C }\end{array}$ & & $\begin{array}{l}\mathbf{R} \\
\mathbf{R}\end{array}$ & $\begin{array}{l}\mathrm{A} \\
\mathrm{C}\end{array}$ & & $\begin{array}{l}R \\
R\end{array}$ & & $\begin{array}{l}\mathrm{F} \\
\mathrm{F}\end{array}$ & & $\begin{array}{ll}\mathrm{F} & \mathrm{F} \\
\mathrm{R} & \mathrm{F}\end{array}$ & & $\begin{array}{l}\mathbf{R} \\
\mathbf{R}\end{array}$ \\
\hline & & & $\mathrm{CN} 3$ & $335-336$ & $\mathrm{v}$ & M & I & F $R$ & & $\mathrm{C}$ & $\mathrm{P}$ & C & A & A & & & $\mathbf{R}$ & & R & & $\mathbf{R}$ & R & $\mathrm{R} \quad \mathrm{C}$ & & R \\
\hline & & & $\mathrm{CN} 2$ & $\begin{array}{l}384-385 \\
441-442\end{array}$ & $\begin{array}{l}\mathrm{v} \\
\mathrm{v}\end{array}$ & $\begin{array}{l}\mathrm{M} \\
\mathrm{M}\end{array}$ & & $\begin{array}{l}\mathrm{R} \\
\mathrm{R}\end{array}$ & & $\begin{array}{l}\mathrm{C} \\
\mathrm{C}\end{array}$ & $\begin{array}{l}\mathbf{R} \\
\mathbf{R}\end{array}$ & $\begin{array}{l}\text { C } \\
\text { C }\end{array}$ & $\begin{array}{l}\text { A } \\
\text { A }\end{array}$ & $\begin{array}{l}\mathrm{A} \\
\mathrm{A}\end{array}$ & $\mathrm{F}$ & & & & $\begin{array}{l}R \\
R\end{array}$ & & & $\begin{array}{l}\mathrm{R} \\
\mathrm{F}\end{array}$ & C & & $\begin{array}{l}\mathrm{F} \\
\mathrm{R}\end{array}$ \\
\hline
\end{tabular}

Note: Abundance and preservation as defined in Table 1.

Table 9. Distribution of calcareous nannofossils in Core E24-16. Core is flow-in between $420 \mathrm{~cm}$ and $1169 \mathrm{~cm}$. A lithologic description of this core can be found in Goodell (1968).

\begin{tabular}{|c|c|c|c|c|c|c|c|c|c|c|c|c|c|c|c|c|c|c|c|c|c|}
\hline $\begin{array}{l}\text { Lithologic } \\
\text { unit }\end{array}$ & Age & Zone & $\begin{array}{c}\text { Sample } \\
\text { (interval in } \mathrm{cm} \text { ) }\end{array}$ & 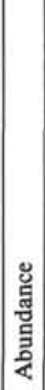 & 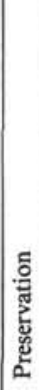 & 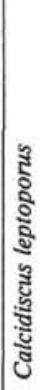 & : & 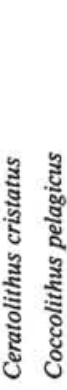 & 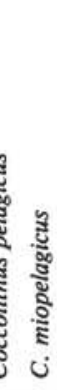 & z & 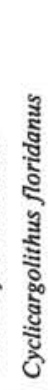 & 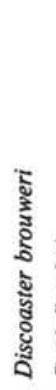 & 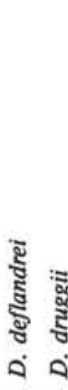 & 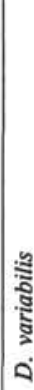 & 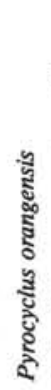 & 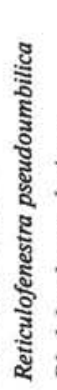 & 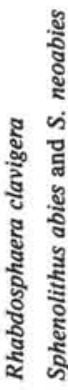 & 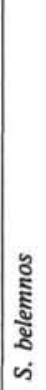 & 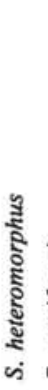 & $\begin{array}{l}\text { है } \\
\text { हे } \\
\text { के }\end{array}$ & 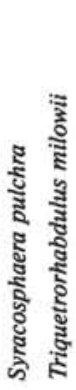 \\
\hline I & Pliocene/Pleistocene & $?$ & $6-7$ & A & M & F & $\mathrm{F} F$ & F C & & $\mathbf{F}$ & A & $\mathbf{R}$ & C & R & & $\mathrm{C}$ & C $\mathrm{C}$ & & $\mathrm{F}$ & $\mathbf{F}$ & $\mathbf{R}$ \\
\hline IIA & \multirow[b]{2}{*}{$\begin{array}{c}\text { early } \\
\text { Miocene }\end{array}$} & $\mathrm{CN} 4+3$ & $\begin{array}{l}18-19 \\
95-96\end{array}$ & \begin{tabular}{l|} 
A \\
V
\end{tabular} & $\begin{array}{l}\mathrm{M} \\
\mathrm{M}\end{array}$ & $\begin{array}{l}\mathrm{F} \\
\mathrm{F}\end{array}$ & $\begin{array}{l}\mathbf{F} \\
\mathbf{R}\end{array}$ & $\begin{array}{l}\mathrm{C} \\
\mathrm{C}\end{array}$ & $\mathrm{F}$ & $\begin{array}{l}F \\
F\end{array}$ & $\begin{array}{l}\text { A } \\
\text { A }\end{array}$ & & $\begin{array}{ll}\text { C } & \\
\text { A } & R\end{array}$ & F & $\mathbf{R}$ & $\begin{array}{l}\mathrm{C} \\
\mathrm{F}\end{array}$ & $\begin{array}{l}\mathrm{C} \\
\mathrm{F}\end{array}$ & & $\begin{array}{l}F \\
F\end{array}$ & $\begin{array}{l}\mathrm{F} \\
\mathrm{F}\end{array}$ & $\begin{array}{l}\mathbf{R} \\
\mathbf{R}\end{array}$ \\
\hline IIB & & $\begin{array}{l}\text { Sphenolithus } \\
\text { belemnos } \\
\text { Zone (CN2) }\end{array}$ & $\begin{array}{l}136-137 \\
164-165 \\
195-196 \\
226-227 \\
299-300 \\
416-417\end{array}$ & \begin{tabular}{|l|}
$\mathrm{v}$ \\
$\mathrm{v}$ \\
$\mathrm{v}$ \\
$\mathrm{v}$ \\
$\mathrm{v}$ \\
$\mathrm{v}$
\end{tabular} & $\begin{array}{l}\mathrm{M} \\
\mathrm{M} \\
\mathrm{M} \\
\mathrm{M} \\
\mathrm{M} \\
\mathrm{M}\end{array}$ & \begin{tabular}{|l}
$\mathrm{F}$ \\
$\mathrm{F}$ \\
$\mathrm{F}$ \\
$\mathrm{F}$ \\
$\mathrm{F}$ \\
$\mathrm{F}$
\end{tabular} & $\begin{array}{l}\mathbf{R} \\
\mathbf{R} \\
\mathbf{R} \\
\mathrm{R} \\
\mathrm{R}\end{array}$ & $\begin{array}{l}\text { A } \\
\text { C } \\
\text { A } \\
\text { C } \\
\text { C } \\
\text { A }\end{array}$ & $\begin{array}{l}F \\
F \\
F \\
F \\
F \\
F\end{array}$ & $\begin{array}{l}\mathrm{F} \\
\mathrm{F} \\
\mathrm{F} \\
\mathrm{F} \\
\mathrm{R} \\
\mathrm{F}\end{array}$ & $\begin{array}{l}\text { A } \\
\text { A } \\
\text { A } \\
\text { A } \\
\text { A } \\
\text { A }\end{array}$ & & $\begin{array}{ll}\text { A } & \text { R } \\
\text { A } & \\
\text { A } & \\
\text { A } & \\
\text { A } & \\
\text { A } & \end{array}$ & & $\mathbf{R}$ & $\begin{array}{l}\mathrm{F} \\
\mathrm{F} \\
\mathrm{C} \\
\mathrm{F} \\
\mathrm{F} \\
\mathrm{F}\end{array}$ & $\mathbf{R}$ & $\begin{array}{l}\mathrm{R} \\
\mathrm{R} \\
\mathrm{R}\end{array}$ & & $\begin{array}{l}\text { F } \\
\text { F } \\
\text { C } \\
\text { C } \\
\text { C } \\
\text { C }\end{array}$ & \\
\hline
\end{tabular}

Note: Abundance and preservation as defined in Table 1.

Additional samples from Cores 599-2 through -4 were taken from the various alternating light-colored and darkcolored sediments to determine any correlations between the presence of $D$. neohamatus and $M$. convallis within the dark-colored layers and the presence of $D$. surculus and/or $A$. primus within the light-colored sediments.

The correlation of these four species with the lightcolored and dark-colored sediments is best seen within Sections 599-2-3 and -4, Section 599-3-3, and Section 599B-2-3. It is less obvious in Section 599-2-2 and in Sections 599-3-1 and -4 (Fig. 5). It is most obvious where the sediment color change is greatest. From this, it is concluded that the presence of $A$. primus and $D$. surculus within the light-colored layers is from normal pelagic deposition, whereas the presence of $D$. neohamatus and $M$. convallis within the dark-colored layers is reworked. This would indicate that the dark-colored bands of sediment were originally deposited approximately 1 to $2 \mathrm{~m}$.y. before the underlying light-colored sediments and postdepositionally transported to their present position. This scenario would also imply that the anomalously high concentration of metalliferous sediments in the darker layers (Fig. 6) is not entirely due to increased volcanic activity caused by a faster spreading rate, but that they may have been further concentrated after deposition.

A grain size analysis from sediment in Sections 599$3-1,-3$, and -4 also indicates a higher energy environment, as shown by coarser particles within the dark-col- 


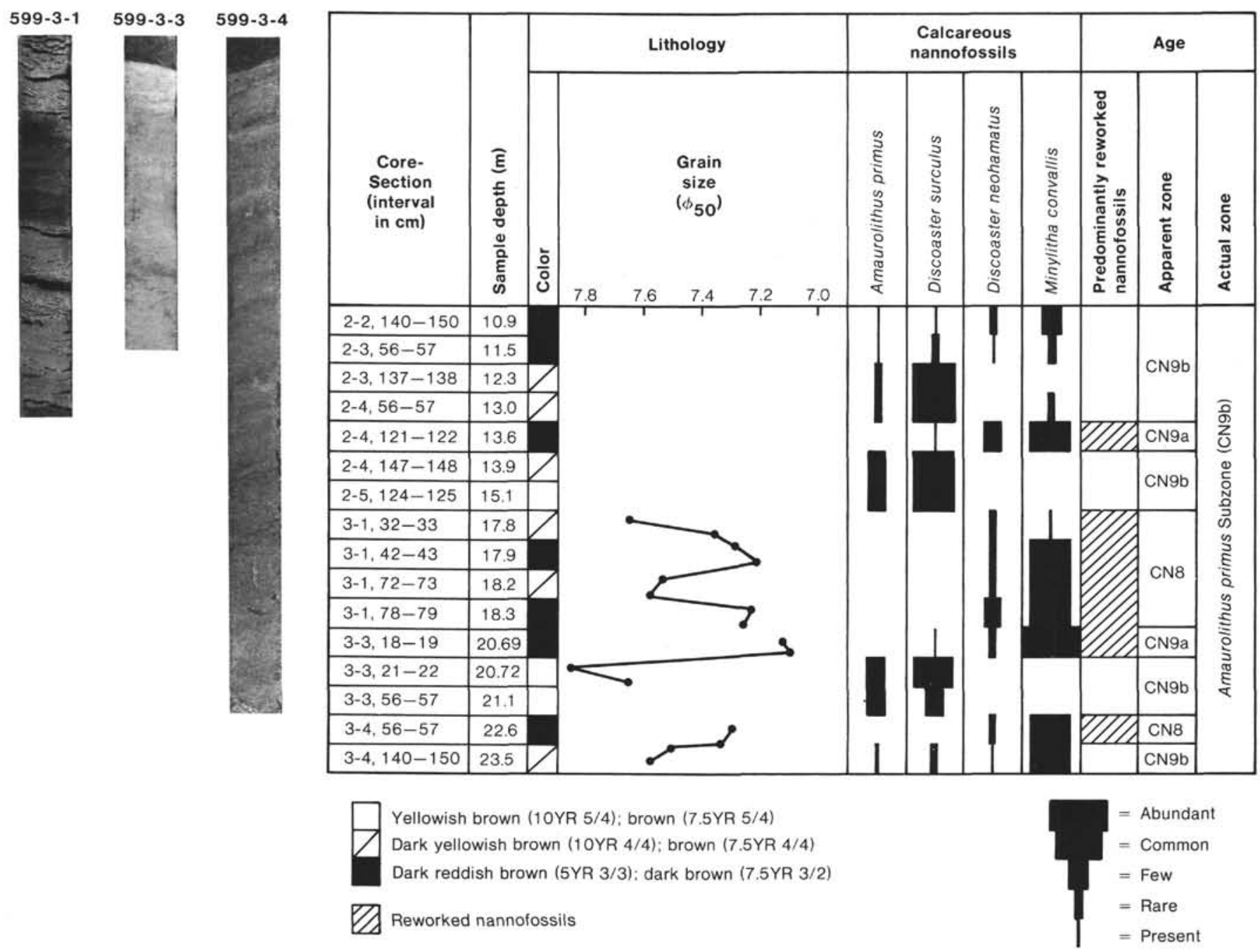

Figure 5. Correlations of sediment color, grain size (Rea and Janecek, this volume), and selected nannofossils present in various samples from Hole 599. Grain size data were plotted to correspond with the same alternating light- or dark-colored band.

ored sediments (Rea and Janecek, this volume). This higher energy environment was apparently strong enough to mask the effects of normal pelagic deposition.

\section{CONCLUSIONS}

A relatively complete upper Oligocene through Holocene section was recovered from six sites during DSDP Leg 92. Sedimentation rates determined from the nannofossil data are low (site chapters, this volume). In some cases the very low rates may indicate minor hiatuses within the middle and upper Miocene. A late Pliocene hiatus may also be present. Most sediments are carbonate rich, with only a small interval of noncalcareous material present at Site 597 (0.3 to $1.4 \mathrm{~m})$. This site is the only Leg 92 site that records an extended history of deposition below the carbonate compensation depth. Similar occurrences of noncarbonate sediment are found within Eltanin Cores E21-2 and E21-3 (approximately 0.3 to $2.0 \mathrm{~m}$ ). Nannofossils present in sediments from Site 598 (11.3 to $19.4 \mathrm{~m}$ ) show stages of advanced dissolution that indicates proximity to the CCD. These observations, along with the studies of percent carbonate (Leinen, this volume), show that the Pacific CCD history determined from Leg 92 drill sites is consistent with patterns of a minimum CCD depth in the middle to late Miocene; however, the depths indicated are approximately $500 \mathrm{~m}$ shallower (Rea and Leinen, this volume; Fig. 3) than those of other nonequatorial Pacific DSDP drill sites (van Andel et al., 1975; Broecker and Broecker, 1974).

Juxtaposed coccolith assemblages correlated with textural characteristics of the sediments provide strong evidence for downslope processes active on the East Pacific Rise during the late Miocene (review: Evidence for Downslope Transport of Sediment on the East Pacific Rise, Site 599). The timing of these mass movements correlates closely with the Messinian sea level drop and intensified bottom current activity, which have been widely recorded in many ocean basins (Adams et al., 1977; Ciesielski and Wise, 1977). Displaced shallow-water fossils of a similar origin are also recorded in many other tropical and subtropical Pacific DSDP sites (Cook et al., 1976; Rea and Thiede, 1981; Thiede et al., 1981). An alternate explanation for the mechanism triggering downslope movement of these sediments would be tectonic instability associated with possible increased seismic ac- 


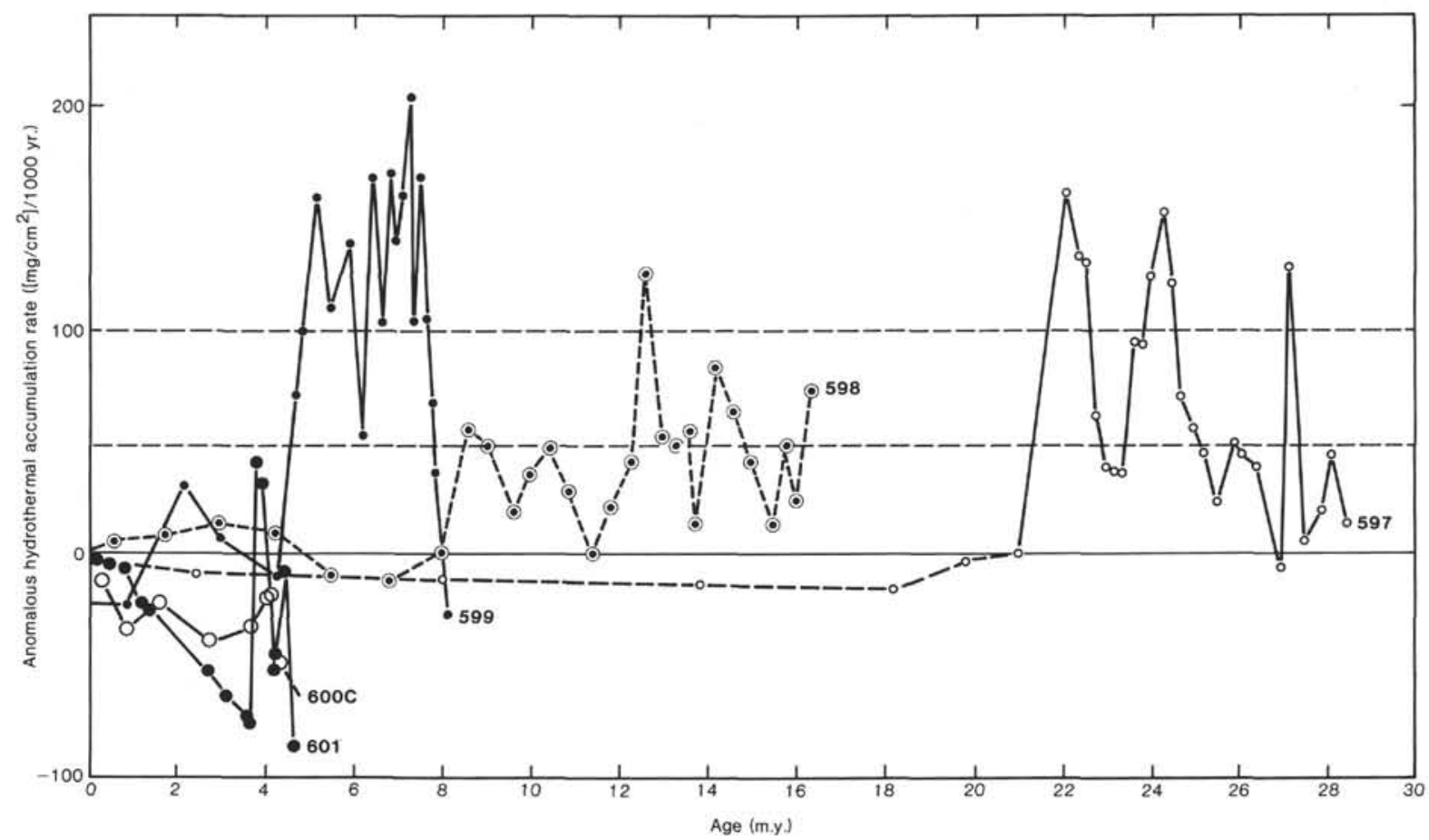

Figure 6. Hydrothermal accumulation rates observed at Leg 92 drill sites. Plot is based on shipboard data only and is observed hydrothermal mass accumulation rate versus sediment age above basement at each site minus the present rate of accumulation.

tivity along the East Pacific Rise (Rea and Janecek, this volume).

Specimens of Discoaster druggii are noted within two separate abundance peaks at Site 597. The earlier abundance peak is used to define the base of the $D$. druggii Subzone $(\mathrm{CN} 1 \mathrm{c})$. The later peak is present within the Sphenolithus belemnos Zone (CN2). The last occurrence of $D$. druggii is noted directly below the first occurrence of $S$. heteromorphus. Large forms of $D$. druggii, within both peaks at Site 597 and those from the U.S.N.S. Eltanin cores, were found to be similar to the large forms referred to as Discoaster sp. aff. D. druggii (Jiang and Gartner, 1984) in Sites 528 and Site 529, Leg 74, from the South Atlantic. The first occurrence of Calcidiscus macintyrei was found to be below its normal range (Bukry, 1975) and occurs with $D$. druggii within the $S$. belemnos Zone (CN2) in all of the studied sites.

Another first occurrence that was found to be very useful, especially with the reworking present at Sites 599 to 601, was that of Pseudoemiliania lacunosa. This first occurrence was closely tied to the extinction of the genus Amaurolithus. It, therefore, was used as a secondary marker species for the boundary between the $A$. tricorniculatus Zone (CN10) and the Reticulofenestra pseudoumbilica Zone (CN11).

\section{ACKNOWLEDGMENTS}

This report was condensed from a Master's thesis presented to the Geology Department of Florida State University (Knüttel, 1984). I thank Dr. S. W. Wise, Jr. and Dr. D. Bukry for critical reviews of the manuscript and for Dr. Wise's suggesting my participation in Leg 92 of the Deep Sea Drilling Project. I am also thankful to James A. Bergen for additional comments in the review process. I am grateful to Thomas H. Lang and George E. Wiegand for valuable discussions on species concepts and for their help, along with that of Susan Leroy, in proofreading. George E. Wiegand is also thanked for the hours of as- sistance in the gloomy depths of the darkroom that were necessary in preparation of the plates. I appreciate the efforts of William I. Miller III, who skillfully operated our terminally ill SEM, and who always kept it running for just one more picture. The helpful suggestions of $F$. Amrisar Kaharoeddin, Dr. V. Toker, and Dr. M.-P. Aubry are greatly appreciated. Jacalynn Blankenship is commended for her typing of the manuscript.

I would like to extend special thanks to Dennis S. Cassidy for his advice and concern throughout the completion of this project and for making the materials and resources of the Antarctic Research Facility available to me.

The often neglected American taxpayer is praised for funding the last 15 yr. of the Deep Sea Drilling Project, which made this report possible. Laboratory support for the project was provided by NSF grants DPP8020382 and DES80205489 to Dr. S. W. Wise, Jr. U.S.N.S. Eltanin core samples were provided by the Antarctic Research Facility of Florida State University, which is funded by NSF contract C-1059 (DPP 75-19723) to Dr. G. W. DeVore.

\section{REFERENCES}

Adams, C. G., Benson, R. H., Kidd, R. B., Ryan, W. B. F., and Wright, R. C., 1977. The Messinian salinity crisis and evidence of late Miocene eustatic changes in the world ocean. Nature, 269: 383-386.

Backman, J., 1980. Miocene-Pliocene nannofossils and sedimentation rates in the Hutton-Rockall Basin, N.E. Atlantic Ocean. Stockholm Contrib. Geol., 36:1-91.

Backman, J., Shackleton, N. J., and Tauxe, L., 1983. Quantitative nannofossil correlation to open ocean deep-sea sections from PlioPleistocene boundary at Vrica, Italy. Nature, 304:156-158.

Berger, W. H., 1973. Cenozoic sedimentation in the eastern tropical Pacific. Geol. Soc. Am. Bull., 84:1941-1954.

Bramlette, M. N., and Wilcoxon, J. A., 1967. Middle Tertiary calcareous nannoplankton of the Cipero Section, Trinidad, W. I. Tulane Stud. Geol., 5:93-131.

Broecker, W. S., and Broecker, S., 1974. Carbonate dissolution on the western flank of the East Pacific Rise. In Hay, W. W. (Ed.), Studies in Paleoceanography. Spec. Publ. Soc. Econ. Paleontol. Mineral., 20:44-57.

Bukry, D., 1971a. Discoaster evolutionary trends. Micropaleontology, $17(1): 43-52$. 
1971b. Coccolith stratigraphy, Leg 8, Deep Sea Drilling Project. In Tracey, J. I., Jr., Sutton, W. D., et al., Init. Repts. DSDP, 8: Washington (U.S. Govt. Printing Office), 791-807. 1973a. Coccolith stratigraphy, eastern equatorial Pacific, Leg 16 Deep Sea Drilling Project. In van Andel, T. H., Heath, G. R., et al., Init. Repts. DSDP, 16: Washington (U.S. Govt. Printing Office), 653-711.

1973b. Low-latitude coccolith biostratigraphic zonation. In Edgar, N. T., Saunders, J. B., et al., Init. Repts. DSDP, 15: Washington (U.S. Govt. Printing Office), 685-703.

1975. Coccolith and silicoflagellate stratigraphy, northwestern Pacific Ocean, Deep Sea Drilling Project, Leg 32. In Larson, T. L., Moberly, R., et al., Init. Repts. DSDP, 32: Washington (U.S. Govt. Printing Office), 677-701.

1976. Coccolith stratigraphy on Manihiki Plateau, Central Pacific, Deep Sea Drilling Project, Site 317. In Schlanger, S. O., Jackson, E. D., et al., Init. Repts. DSDP, 33: Washington (U.S. Govt. Printing Office), 493-501.

1981. Pacific Coast coccolith stratigraphy between Point Conception and Cabo Corrientes, Deep Sea Drilling Project, Leg 63. In Yeats, R. S., Haq, B. U., et al., Init. Repts. DSDP, 63: Washington (U.S. Govt. Printing Office), 445-471.

Bukry, D., and Bramlette, M. N., 1969. Some new stratigraphically useful calcareous nannofossils of the Cenozoic. Tulane Stud. Geol. Paleontol., 7:131-142.

Bukry, D., and Percival, S. F., 1971. New Tertiary calcareous nannofossils. Tulane Stud. Geol. Paleontol., 8:123-146.

Burns, D. A., 1973. Structural analysis of flanged coccoliths in sediments from the southwest Pacific Ocean. Rev. Espan. Micropaleontol., 5:147-160.

Ciesielski, P. F., and Wise, S. W., 1977. Geological history of the Maurice Ewing Bank of the Falkland Plateau (Southwest Atlantic sector of the Southern Ocean) based on piston and drill cores. Mar. Geol., 25:175-207.

Cook, H. E., Jenkyns, H. C., and Kelts, K. R., 1976. Redeposited sediments along the Line Islands, Equatorial Pacific. In Schlanger, S. O., Jackson, E. D., et al., Init. Repts. DSDP, 33: Washington (U.S. Govt. Printing Office), 837-847.

Deacon, G. E. R., 1963. The Southern Ocean. In Hill, M. N. (Ed.), The Sea (Vol. 2): New York (Wiley Interscience), 281-296.

Edwards, A. R., 1973. Calcareous nannofossils from the southwest Pacific, Deep Sea Drilling Project, Leg 21. In Burns, R. E., Andrews, J. E., et al., Init. Repts. DSDP, 21: Washington (U.S. Govt. Printing Office), 641-691.

Edwards, A. R., and Perch-Nielsen, K., 1974. Calcareous nannofossils from the Southwest Pacific, Deep Sea Drilling Project, Leg 29. In Kennett, J. P., Houtz, R. E., et al., Init. Repts. DSDP, 29: Washington (U.S. Govt. Printing Office), 469-539.

Garner, D. M., 1954. Sea surface temperature in the southwest Pacific Ocean, from 1949 to 1952. N.Z. J. Sci. Technol. Sect. B, 36:285303.

Gartner, S., Jr., 1967. Nannofossil species related to Cyclococcolithus leptoporus (Murray \& Blackman). Univ. Kans. Paleontol. Contrib. Pap., 28:1-6.

Gartner, S., Jr., and Bukry, D., 1975. Morphology and phylogeny of the coccolithophycean family Ceratolithaceae. J. Res. U.S. Geol. Surv., 3:451-465.

Gartner, S., Jr., Chen, M. P., and Stanton, R. J., 1983. Late Neogene nannofossil biostratigraphy and paleoceanography of the northeastern Gulf of Mexico and adjacent areas. Mar. Micropaleontol., $8: 17-50$.

Geitzenauer, K. R., 1972. The Pleistocene calcareous nannoplankton of the subantarctic Pacific Ocean. Deep Sea Res., 19:45-60.

Goodell, H. G., 1968. U.S.N.S. Eltanin Core Descriptions, Cruises 16-27. Sed. Res. Lab. Dept. Geol. Florida State Univ. Contrib. 25.

Haq, B. L., 1984. Jurassic to Recent nannofossil biochronology: an update. In Haq, B. L. (Ed.), Nannofossil Biostratigraphy. Benchmark Pap. Geol., 78:358-378.

Haq, B. L., and Takayama, T., 1984. Neogene calcareous nannoplankton datum planes and their calibration to magnetostratigraphy. In Ikebe, N., and Tsuchi, R. (Eds.), Pacific Neogene Datum Planes. Contributions to Biostratigraphy and Chronology: Tokyo (Univ. Tokyo Press), pp. 27-33.
Hay, W. W., 1977. Calcareous nannofossils. In Ramsay, A. T. S. (Ed.), Oceanic Micropaleontology (Vol. 2): New York (Academic Press), 1055-1200.

Hays, J. D., et al., 1972. Init. Repts. DSDP, 9: Washington (U.S. Govt. Printing Office).

Heath, G. R., 1969. Carbonate sedimentation in the abyssal equatorial Pacific during the past 50 million years. Geol. Soc. Am. Bull., 80:689-694.

Heck, S. E. van, 1979a. Bibliography and taxa of calcareous nannoplankton. Int. Nannoplankton Assoc. Newsl., 1:AB1-5, A1-12, B1-27.

, 1979b. Bibliography and taxa of calcareous nannoplankton. Int. Nannoplankton Assoc. Newsl., 1:AB VI, A13-28, B28-42.

1980a. Bibliography and taxa of calcareous nannoplankton. Int. Nannoplankton Assoc. Newsl., 2:5-34.

1980b. Bibliography and taxa of calcareous nannoplankton. Int. Nannoplankton Assoc. Newsl., 2:43-81.

1981a. Bibliography and taxa of calcareous nannoplankton. Int. Nannoplankton Assoc. Newsl., 3:4-41.

1981b. Bibliography and taxa of calcareous nannoplankton. Int. Nannoplankton Assoc. Newsl., 3:51-86.

1982a. Bibliography and taxa of calcareous nannoplankton. Int. Nannoplankton Assoc. Newsl., 4:7-50.

1982b. Bibliography and taxa of calcareous nannoplankton. Int. Nannoplankton Assoc. Newsl., 4:65-96.

1983a. Bibliography and taxa of calcareous nannoplankton. Int. Nannoplankton Assoc. Newsl., 5:4-13.

1983b. Bibliography and taxa of calcareous nannoplankton. Int. Nannoplankton Assoc. Newsl., 5:29-47.

, 1984. Bibliography and taxa of calcareous nannoplankton. Int. Nannoplankton Assoc. Newsl., 6:6-37.

Honjo, S., and Okada, H., 1974. Community str"cture of coccolithophorids in the photic layer of the mid-Pacific Ocean. Micropaleontology, 20:209-230.

Jiang, M. J., and Gartner, S., 1984. Neogene and Quaternary calcareous nannofossil biostratigraphy of the Walvis Ridge. In Moore, T. C., Jr., Rabinowitz, P. D., et al., Init. Repts. DSDP, 74: Washington (U.S. Govt. Printing Office), 561-595.

Kamptner, E., 1955. Fossile Coccolithineen-Skelettreste aus Insulinde: eine mikropalaeontologische Untersuchung. Verh. K. Ned. Akad. Wet. Afd. Natuurk. Reeks 2, 50:1-105.

1956. Sitzung der mathematisch-naturwissenschaftlichen Klasse vom 12. Januar 1956. Oesterr. Akad. Wiss., 1:4-11.

Kennett, J. P., and Geitzenauer, K. R., 1969. Pliocene-Pleistocene boundary in a South Pacific deep-sea core. Nature, 224(5222):899901.

Kennett, J. P., McBirney, A. R., and Thunell, R., 1977. Episodes of Cenozoic volcanism in the circum-Pacific region. J. Volcanol. Geotherm Res., 2:145-163.

Klinkhammer, G., and Hudson, A., in press. The hydrothermal manganese plume in the South Pacific. Earth Planet. Sci. Lett.

Knüttel, S., 1984. Calcareous nannofossil biostratigraphy of the central East Pacific Rise, DSDP Leg 92: evidence for downslope transport of sediments [Master's thesis]. Florida State Univ., Tallahassee.

Loeblich, A. R., and Tappan, H., 1966. Annotated index and bibliography of the calcareous nannoplankton I. Phycologia, 5(2/3):81216.

1968. Annotated index and bibliography of the calcareous nannoplankton II. J. Paleontol., 42:584-598.

1969. Annotated index and bibliography of the calcareous nannoplankton III. J. Paleontol., 43:568-588.

1970a. Annotated index and bibliography of the calcareous nannoplankton IV. J. Paleontol, 44:558-574.

$1970 \mathrm{~b}$. Annotated index and bibliography of the calcareous nannoplankton V. Phycologia, 9:157-174.

1971. Annotated index and bibliography of the calcareous nannoplankton VI. Phycologia, 10:315-339.

1973. Annotated index and bibliography of the calcareous nannoplankton VII. J. Paleontol, 47:715-759.

, 1978. The coccolithophorid genus Calcidiscus Kamptner and its synonyms. J. Paleontol, 52:1390-1392.

McIntyre, A., Bé, A. W. H., and Preikstas, R., 1967. Coccoliths and the Pliocene-Pleistocene boundary. Prog. Oceanogr., 4:3-25. 
McIntyre, A., Bé, A. W. H., and Roche, M. B., 1970. Modern Pacific coccolithophorida: a paleontological thermometer. Trans. N.Y. Acad. Sci., 32(6):720-731.

Martini, E., 1965. Mid-Tertiary calcareous nannoplankton from the Pacific deep-sea cores. Proc. 17th Symposium Colston Res. Soc.: London (Butterworths Scientific Publ.). , 1971. Standard Tertiary and Quaternary calcareous nannoplankton zonation. In Farinacci, A. (Ed.), Proc. Second Planktonic Conf. (Vol. 2): Rome (Tecnoscienza), 739-785.

Martini, E., and Bramlette, M. N., 1963. Calcareous nannoplankton from the experimental Mohole drilling. J. Paleontol., 37(4).

Okada, H., and Bukry, D., 1980. Supplementary modification and introduction of code numbers to the low-latitude coccolith biostratigraphic zonation (Bukry, 1973; 1975). Mar. Micropaleontol., 5: 321-325.

Okada, H., and Honjo, S., 1973. The distribution of oceanic coccolithophorids in the Pacific. Deep Sea Res., 20:355-374.

Rea, D. K., and Scheidegger, K. F., 1979. Eastern Pacific spreading rate fluctuation and its relation to Pacific area volcanic episodes. $J$. Volcanol. Geotherm. Res., 5:135-148.

Rea, D. K., and Thiede, J., 1981. Mesozoic and Cenozoic mass-accumulation rates of the major sediment components in the Nauru Basin, western Equatorial Pacific. In Larson, R. L., Schlanger, S. O., et al., Init. Repts. DSDP, 61: Washington (U.S. Govt. Printing Office), 549-555.

Romein, A. J. T., 1979. Evolutionary lineages in early Paleogene calcareous nannoplankton. Utrecht Micropaleontol. Bull., 22.

Thiede, J., Boersma, A., Schmidt, R. R., and Vincent, E., 1981. Reworked fossils in Mesozoic and Cenozoic pelagic central Pacific Ocean sediments, Deep Sea Drilling Project Sites 463, 464, 465, and 466, Leg 62. In Thiede, J., Vallier, T. L., et al., Init. Repts. DSDP, 62: Washington (U.S. Govt. Printing Office), 495-512.

Tracy, J. I., Jr., Sutton, W. D., et al., 1971. Init. Repts. DSDP, 8: Washington (U.S. Govt. Printing Office).

van Andel, T. H., Heath, G. R., and Moore, T. C., Jr., 1975. Cenozoic history and paleoceanography of the central equatorial Pacific Ocean. Mem. Geol. Soc. Am., 143.

Wise, S. W., Jr., and Wind, F. H., 1976. Mesozoic and Cenozoic calcareous nannofossils recovered by DSDP Leg 36 drilling on the Falkland Plateau, Southwest Atlantic sector of the Southern Ocean. In Barker, P. F., Dalziel, I. W. D., et al., Init. Reports. DSDP, 36: Washington (U.S. Govt. Printing Office), 269-492.

Yeats, R. S., Hart, S. R., et al., 1976. Init. Repts. DSDP, 34: Washington (U.S. Govt. Printing Office).

Date of Initial Receipt: 10 September 1984

Date of Acceptance: 2 January 1985

\section{APPENDIX A}

\section{Calcareous Nannofossils Considered in this Report}

The calcareous nannofossil species considered in this chapter are listed here and arranged alphabetically by their specific epithets. Bibliographic references for those taxa not listed within the reference section are presented by Loeblich and Tappan $(1966,1968,1969,1970 \mathrm{a}$, $1970 \mathrm{~b}, 1971,1973)$ or by van Heck $(1979 \mathrm{a}, 1979 \mathrm{~b}, 1980 \mathrm{a}, 1980 \mathrm{~b}$, 1981a, 1981b, 1982a, 1982b, 1983a, 1983b, 1984).

Sphenolithus abies Deflandre, 1953

Cyclicargolithus abisectus (Müller) Wise, 1973

Ceratolithus acutus Gartner \& Bukry, 1974

Discoaster adamanteus Bramlette \& Wilcoxon, 1967

Chiasmolithus altus Bukry \& Percival, 1971

Amaurolithus amplificus (Bukry \& Percival) Gartner \& Bukry, 1975

Scyphosphaera apsteinii Lohmann, 1902

Discoaster asymmetricus Gartner, 1969

Sphenolithus belemnos Bramlette \& Wilcoxon, 1967

Discoaster bellus Bukry \& Percival, 1971

Discoaster berggrenii Bukry, 1971

Zygrhablithus bijugatus (Deflandre) Deflandre, 1959

Dictyococcites bisectus (Hay, Mohler \& Wade) Bukry \& Percival, 1971

Amaurolithus bizzarus (Bukry) Gartner \& Bukry, 1975

Discoaster braarudii Bukry, 1971

Discoaster brouweri Tan, 1927
Catinaster calyculus Martini \& Bramlette, 1963

Scyphosphaera campanula Deflandre, 1942

Sphenolithus capricornutus Bukry \& Percival, 1971

Triquetrorhabdulus carinatus Martini, 1965

Helicosphaera carteri (Wallich) Kamptner, 1954

Discoaster challengeri Bramlette \& Riedel, 1954

Sphenolithus ciperoensis Bramlette \& Wilcoxon, 1967

Rhabdosphaera clavigera Murray \& Blackman, 1898

Catinaster coalitus Martini \& Bramlette, 1963

Sphenolithus conicus Bukry, 1971

Minylitha convallis Bukry, 1973

Ceratolithus cristatus Kamptner, 1950

Discoaster decorus (Bukry) Bukry, 1973

Discoaster deflandrei Bramlette \& Wilcoxon, 1967

Amaurolithus delicatus Gartner \& Bukry, 1975

Sphenolithus delphix Bukry, 1973

Sphenolithus dissimilis Bukry \& Percival, 1971

Discoaster druggii Bramlette \& Wilcoxon, 1967

Coccolithus eopelagicus Bramlette \& Riedel, 1954

Discoaster exilis Martini \& Bramlette, 1963

Chiasmolithus expansus (Bramlette \& Sullivan) Gartner, 1970

Clausicoccus fenestratus (Deflandre \& Fert) Prins, 1979

Cyclicargolithus floridanus (Roth \& Hay) Bukry, 1971

Coccolithus formosus (Kamptner) Wise, 1973

Scapholithus fossilis Deflandre, 1954

Coccolithus fuscus Backman, 1980

Gephyrocapsa sp. (small)

Scyphosphaera globulata Bukry \& Percival, 1971

Discoaster hamatus Martini \& Bramlette, 1963

Sphenolithus heteromorphus Deflandre, 1953

Emiliania huxleyi (Lohmann) Hay \& Mohler, in Hay et al., 1976

Discoaster intercalaris Bukry, 1971

Helicosphaera intermedia Martini, 1965

Scyphosphaera intermedia Deflandre, 1942

Calcidiscus leptoporus (Murray \& Blackman) Loeblich \& Tappan, 1978

Calcidiscus macintyrei (Bukry \& Bramlette) Loeblich \& Tappan, 1978

Triquetrorhabdulus milowii Bukry, 1971

Coccolithus miopelagicus Bukry, 1971

Umbilicosphaera mirabilis Lohmann, 1902

Discoaster moorei Bukry, 1971

Sphenolithus moriformis (Brönnimann \& Stradner) Bramlette \& Wilcoxon, 1967

Sphenolithus neoabies Bukry \& Bramlette, 1969

Discoaster neohamatus Bukry \& Bramlette, 1969

Coronocyclus nitescens (Kamptner) Bramlette \& Wilcoxon, 1967

Gephyrocapsa oceanica Kamptner, 1943

Pyrocyclus orangensis (Bukry) Backman, 1980

Coccolithus pelagicus (Wallich) Schiller, 1930

Discoaster pentaradiatus Tan, 1927

Hayaster perplexus (Bramlette \& Riedel) Bukry, 1973

Pontosphaera sp.

Discoaster prepentaradiatus Bukry \& Percival, 1971

Amaurolithus primus (Bukry \& Percival) Gartner \& Bukry, 1975

Rhabdosphaera procera Martini, 1969

Reticulofenestra pseudoumbilica (Gartner) Gartner, 1969

Scyphosphaera pulcherrima Deflandre, 1942

Syracosphaera pulchra Lohmann, 1902

Discoaster quinqueramus Gartner, 1969

Reticulofenestra spp. (small)

Note: This name is also used to denote species formerly ascribed to Crenalithus doronicoides; see Backman (1980).

Ceratolithus rugosus Bukry \& Bramlette, 1968

Triquetrorhabdulus rugosus Bramlette \& Wilcoxon, 1967

Pontosphaera segmenta (Bukry) Knüttel nov. comb.

Helicosphaera sellii (Bukry \& Bramlette) Jafar \& Martini, 1975

Discoaster surculus Martini \& Bramlette, 1963

Discoaster tamalis Kamptner, 1967

Thoracosphaera sp.

Amaurolithus tricorniculatus (Gartner) Gartner \& Bukry, 1975

Discoaster tridenus (Kamptner) Bukry, 1981

Reticulofenestra umbilica (Levin) Martini \& Ritzkowski, 1968

Sphenolithus umbrellus (Bukry) Aubrey \& Knüttel, nov. comb.

Discoaster variabilis Martini \& Bramlette, 1963 


\section{APPENDIX B \\ Systematic Paleontology}

\section{Genus CALCIDISCUS Kamptner, 1950}

\section{Calcidiscus macintyrei (Bukry and Bramlette) Loeblich and Tappan, 1978 \\ (Plate 1, Figs. 9, 10)}

(Plate 2, Fig. 1; Plate 3, Fig. 2)

(?) Cyclococcolithus tropicus Kamptner, 1955, p. 32 (invalid, ICBN article 34 nom. altern., fide Loeblich and Tappan, 1966).

(?) Coccolithus tropicus Kamptner, 1955, pp. 98-99, fig. 79 (invalid, ICBN article 34, nom. altern., fide Loeblich and Tappan, 1966).

(?) Calcidiscus tropicus Kamptner, 1956, p. 9 (validated by reference to description and figure previously published under invalid name, fide Loeblich and Tappan, 1966).

Calcidiscus medusoides Kamptner, 1954. Martini and Bramlette, 1963, p. 849, pl. 102 , figs. $1,2$.

Coccolithus leptoporus (Murray and Blackman) var. A, McIntyre, Bé, and Preikstas, 1967, pp. 9-10, pl. 4, figs. C, D.

Cyclococcolithus leptoporus (Murray and Blackman) Gartner, 1967, p. 1, pl. 1 figs. 1, 2, 4a-4c; pl. 2, figs. 1, 4a-4d.

Cyclococcolithus macintyrei Bukry and Bramlette, 1969, pp. 132-133, pl. 1, figs. 1-3.

Calcidiscus macintyrei (Bukry and Bramlette) Loeblich and Tappan, 1978.

(?) Cyclococcolithus tropicus (Kamptner) Gartner et al., 1983, p. 46. Remarks. Lower Miocene specimens of Calcidiscus macintyrei are poorly preserved and are most often observed within the examined material as isolated distal shields. These shields are somewhat smaller $(9 \mu \mathrm{m})$ and have fewer elements (approximately 37; Plate 1, Figs. 9 and 10; Plate 3, Fig. 2) than the type specimen (Bukry and Bramlette, 1969; McIntyre et al., 1967), which has approximately 40 elements and is $11 \mu \mathrm{m}$ across the distal shield. These forms, which at Site 597 are referred to as $C$. macintyrei s. ampl., are within the size range given in the type description ( 8 to $12 \mu \mathrm{m}$ ) and are therefore considered to be within the taxonomic variation of $C$. macintyrei.

Occurrence. Calcidiscus macintyrei s. ampl. is found below the last occurrence of Sphenolithus belemnos in sediments from Site 597 and Core E24-16. It is also observed in Sample 528-4-2 (80-82 cm) from the South Atlantic (Plate 2, Fig. 1), but was most likely recorded as Calcidiscus leptoporus (Jiang and Gartner, 1984). The first occurrence of Calcidiscus macintyrei s. ampl. below the second abundance peak of Discoaster druggii may be indicative of the upper Sphenolithus belemnos Zone within moderate latitudes when the guide species $S$. belemnos is rare or poorly preserved. The occurrence of C. macintyrei is similarly reported within the range of Discoaster druggii in the equatorial Pacific in Core K78016 (Haq and Takayama, 1984).

Note. The name Cyclococcolithus tropicus Kamptner as used by Gartner et al. (1983) is not adopted in this report because the illustration by Kamptner (1955, p. 99) is somewhat interpretive and its optical properties under crossed-polarized light are not discussed. The rim proportions and attitudes of C. macintyrei (Gartner, 1967, pl. 2) also appear to be different (D. Bukry, pers. comm., 1984). The type material should be re-examined before this name is accepted. The new combination proposed by Gartner et al. (1983) would be redundant if the original name proposed by Kamptner (1955, p. 32), Cyclococcolithus tropicus, is considered valid. However, Kamptner's illustration (his figs. 79a and b) was incorrectly(?) referred to as Coccolithus tropicus. Therefore, Loeblich and Tappan (1966, pp. 100 and 113) found both of these combinations to be invalid and refer to Kamptner $(1956$, p. 9) for a valid recombination. The genus Cyclococcolithus has also been rejected by Loeblich and Tappan (1978). If it is found that the specific name macintyrei is a junior synonym of tropicus, the generic name Calcidiscus should be applied to this form [i.e., Calcidiscus tropicus (Kamptner) Kamptner, 1956].

\section{Genus DISCOASTER Tan}

\section{Discoaster druggii Bramlette and Wilcoxon, 1967}

(Plate 1, Figs. 5-8)

(Plate 2, Figs. 1, 2, 5)

(Plate 3, Fig. 1)

Discoaster sp. (ciperoensis gp.) Martini, 1965, p. 405, pl. 37, figs. 10, 11 (pl. 33, figs. 5, 6).
Discoaster druggii Bramlette and Wilcoxon, 1967, p. 110, pl. 8, figs. 2-8.

Remarks. Large forms of Discoaster druggii, up to $32 \mu \mathrm{m}$, are present in material examined from Site 597 and Core E24-16. The rays of these forms vary in shape from blunt and tapering to long and narrow with almost parallel sides. In some specimens, the free length of the arms is equal to or greater than the central area of the astrolith. Forms of this type were not discussed by Bramlette and Wilcoxon (1967; the closest form illustrated is in pl. 8, fig. 2). Upon examination of the type material, forms were found with parallel sides, rays having free arm lengths up to $12 \mu \mathrm{m}$, and central areas measuring up to $8 \mu \mathrm{m}$ (total diameter $=32 \mu \mathrm{m})$. Jiang and Gartner (1984) also referred to large discoasters having straight and slightly tapered rays and recorded them as Discoaster sp. aff. D. druggii. Because the Leg 74 and Leg 92 lower Miocene materials are similar in preservation and assemblage, along with the material from Core E24-16 which is somewhat better preserved, I suggest that the forms documented (however not illustrated) by Jiang and Gartner (1984) are variants of $D$. druggii. The large size of the more robust forms is attributed to heavy secondary overgrowth.

Occurrence. Discoaster druggii (including the very large forms) occurs stratigraphically in two narrow abundance peaks at Site 597 that are separated by an interval in which this species does not occur. The stratigraphic distribution of this species is similar to that reported on other DSDP Legs (Bukry, 1975; 1976). The first abundance peak of D. druggii lies below the first appearance of Sphenolithus belemnos, and the second peak occurs within the $S$. belemnos Zone. The highest stratigraphic occurrence of $D$. druggii is found directly below the first appearance of $S$. heteromorphus, in Core E24-16.

\section{Genus PONTOSPHAERA Lohmann, 1902}

\section{Pontosphaera segmenta (Bukry and Percival) Knüttel, nov. comb.} (Plate 7, Figs. 8-10)

Discolithina segmenta Bukry and Percival, 1971, pp. 130-1, pl. 4, figs. 4-6.

Remarks. The genus Discolithina is considered in this report to be a synonym of Pontosphaera. This is in agreement with Burns (1973), Romein (1979), and Backman (1980).

Occurrence. Pontosphaera segmenta occurs in lower Miocene and upper Oligocene sediment from Site 597. It is rare in most of the samples in which it is present, and it constitutes less than $1 \%$ of the total assemblage.

\section{Genus SPHENOLITHUS Deflandre, 1952}

Sphenolithus umbrellus (Bukry) Aubry and Knüttel, nov. comb.

Catinaster? umbrellus Bukry, 1971a, p. 50, pl. 3, figs. 10-13.

Remarks. Because of the basket-like shape of its nannoliths, this species was provisionally assigned to the genus Catinaster. This assignment is unsatisfactory, because the representatives of the late Miocene genus Catinaster belong to the Ortholithae group, whereas C.? umbrellus exhibits the optical characteristics of the Heliolithae group. Its 8 to 12 rib-like elements act as separate crystals of calcite. Rather, $C$. ? umbrellus shows a very close resemblance to the basal cycle of a sphenolith (see Plate 5). Sphenoliths consist of two parts: (1) a basal cycle or column, and (2) a cone, which may include several more or less well developed cycles consisting of one or more lateral cycles and a centrodorsal spine (Romein, 1979). No well defined apical structure is apparent in specimens of $C$. ? umbrellus that were examined by means of the scanning electron microscope (Plate 5, Figs. 1, 2,8), but with the light microscope several specimens were observed to have a rudimentary apical structure (see Plate 5, Fig. 10). Thus, we interpret $C$.? umbrellus as a sphenolith, characterized by a well developed basal cycle and a small, fragile cone, which in most cases is not preserved. We believe the genus Sphenolithus best accommodates the form presently referred to as Catinaster? umbrellus. Until such time as the species is found to have a verifiable apical structure, we propose that it be renamed Sphenolithus umbrellus (Bukry).

Occurrence. Sphenolithus umbrellus, rare to few in abundance, occurred in upper Oligocene and lowermost Miocene sediments recovered from Site 597 and from DSDP Sites 558 and 563 in the North Atlantic Ocean. Its last occurrence is close to that of $S$. capricornutus, $S$. delphix, Dictyococcites bisectus, and Clausicoccus fenestratus. 


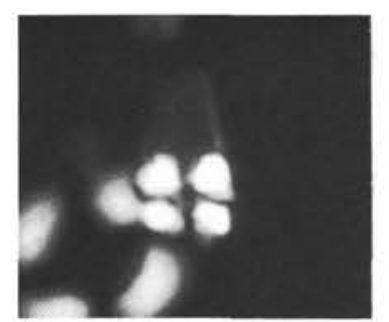

1

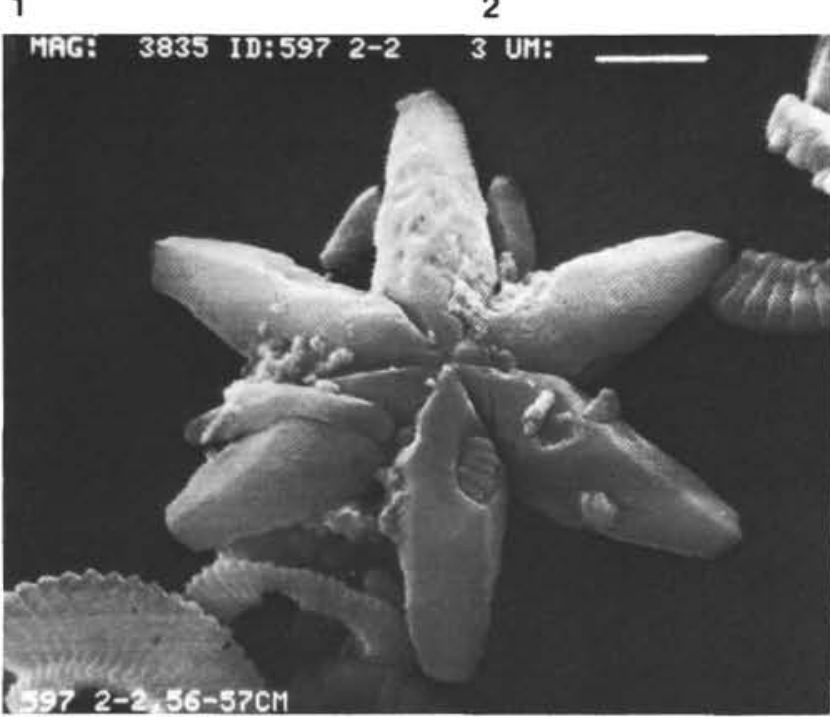

5

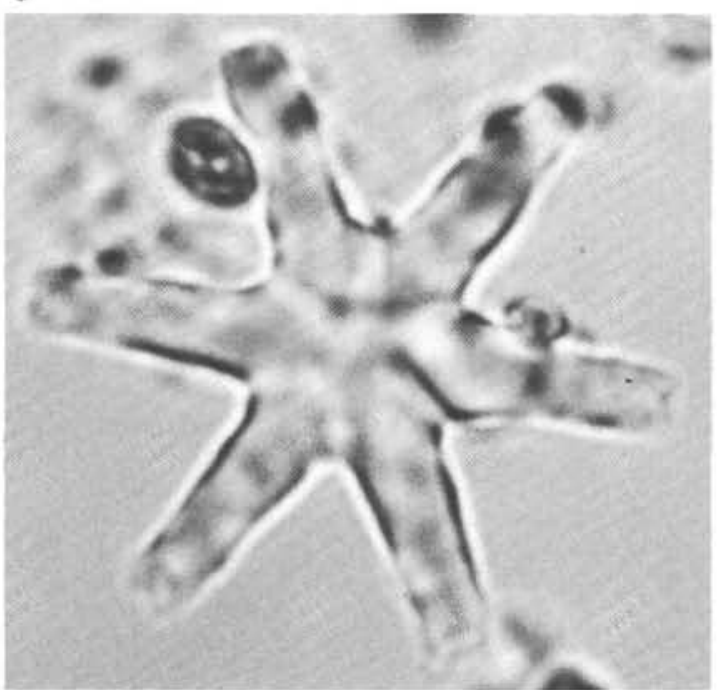

Plate 1. Early or middle Miocene nannofossils. 1, 2. Sphenolithus heteromorphus, Sample 597-1-2, 56-57 cm, 2900×. 3, 4. Sphenolithus belemnos, Section 597-2,CC, $2900 \times$. 5-8. Discoaster druggii; $(5,6)$ Sample $597-2-2,56-57 \mathrm{~cm}, 3835 \times$ and $3640 \times$; $(7,8)$ Sample E24-16, $136-137 \mathrm{~cm}, 2900 \times$. 9, 10. Calcidiscus macintyrei s. ampl., Sample 597A-1-2, 132-133 cm, $2900 \times$. 


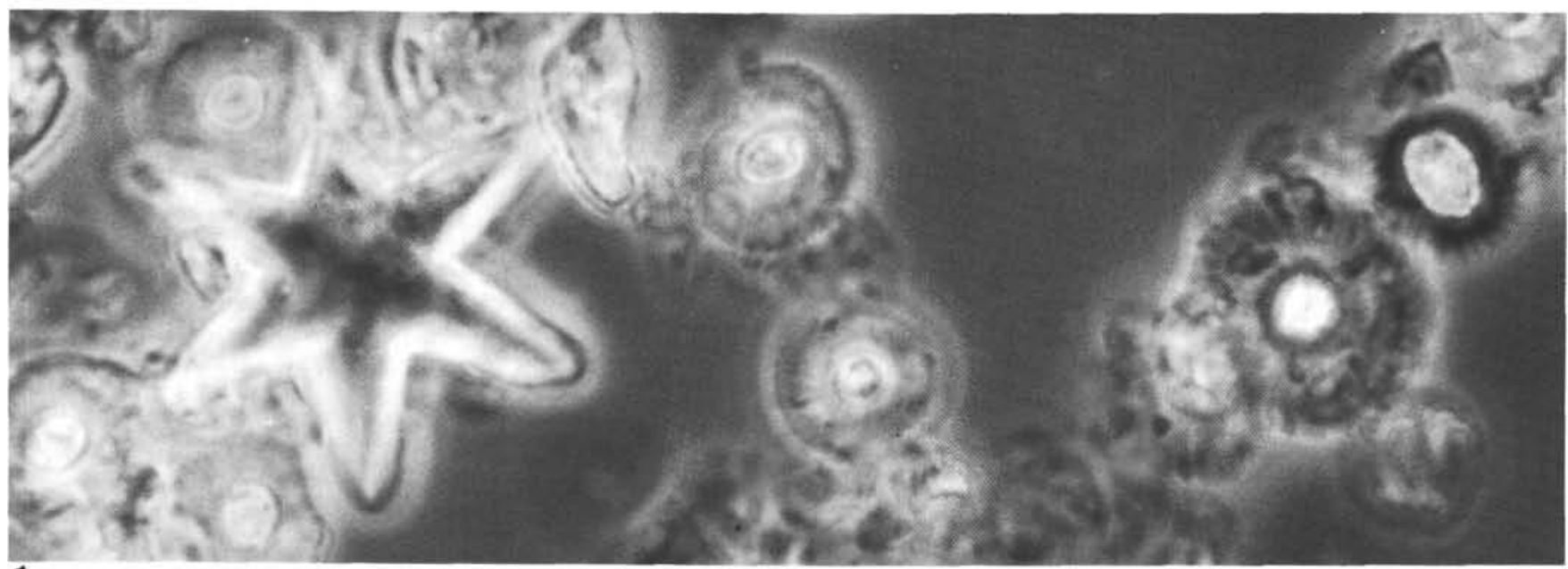

1
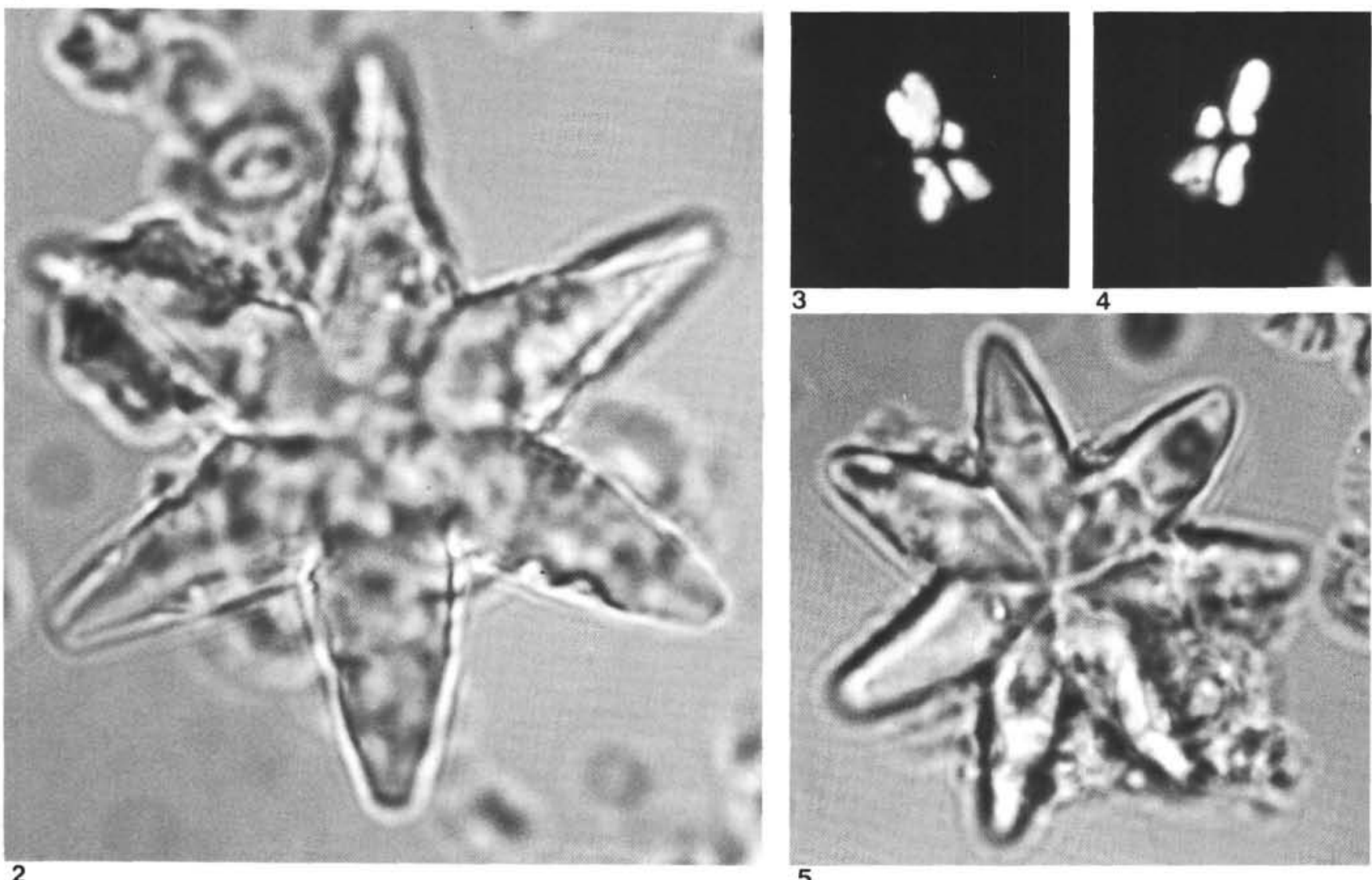

3

4

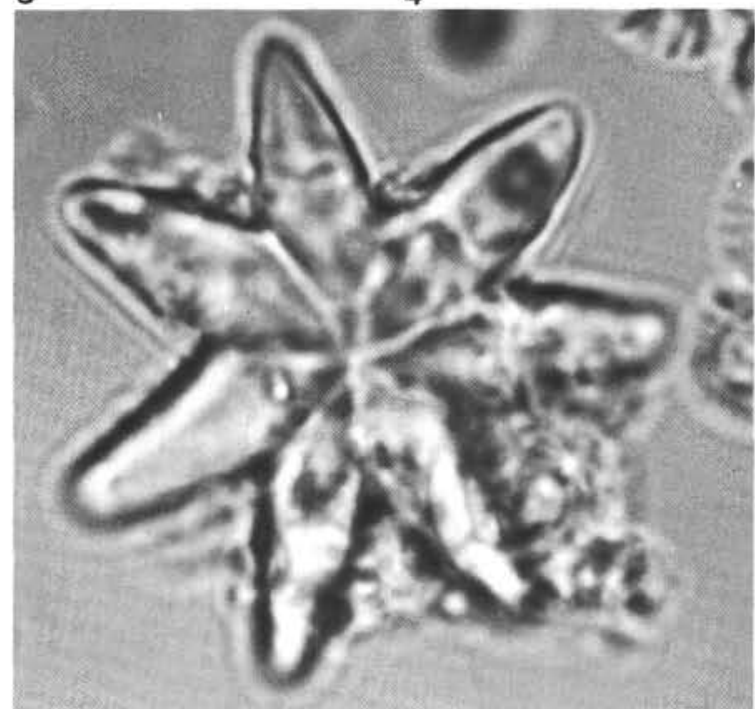

5

Plate 2. Early or middle Miocene nannofossils. 1. Discoaster druggii and Calcidiscus macintyrei, Sample 528-4-2, 80-82 cm, 2900× . 2, 5. Discoaster druggii, Sample 529-9-5, 30-31 cm, $2900 \times$. 3, 4. Sphenolithus belemnos, Section 597-2,CC, $2900 \times$. 


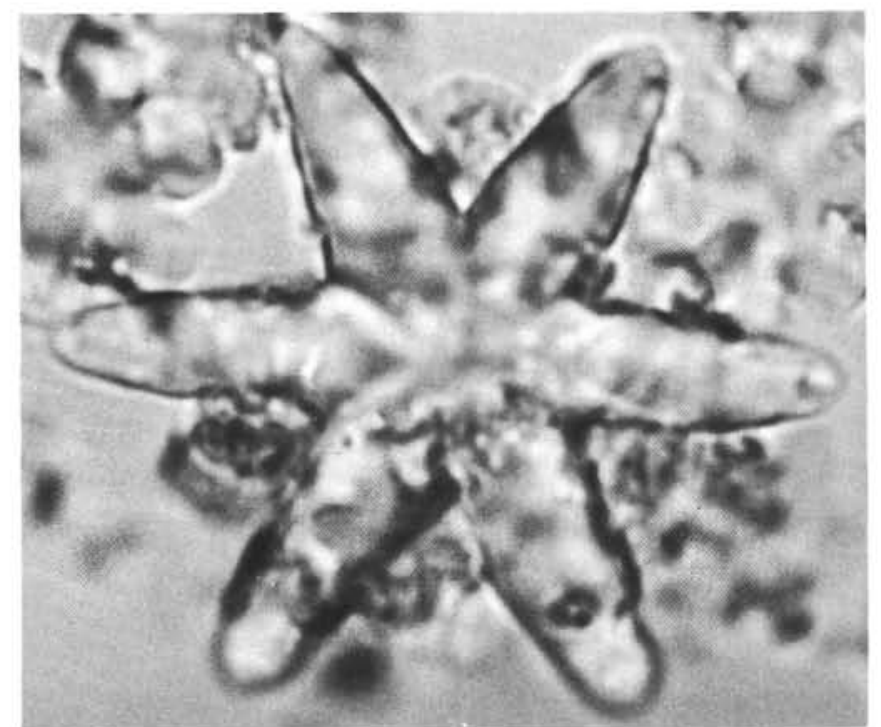

1

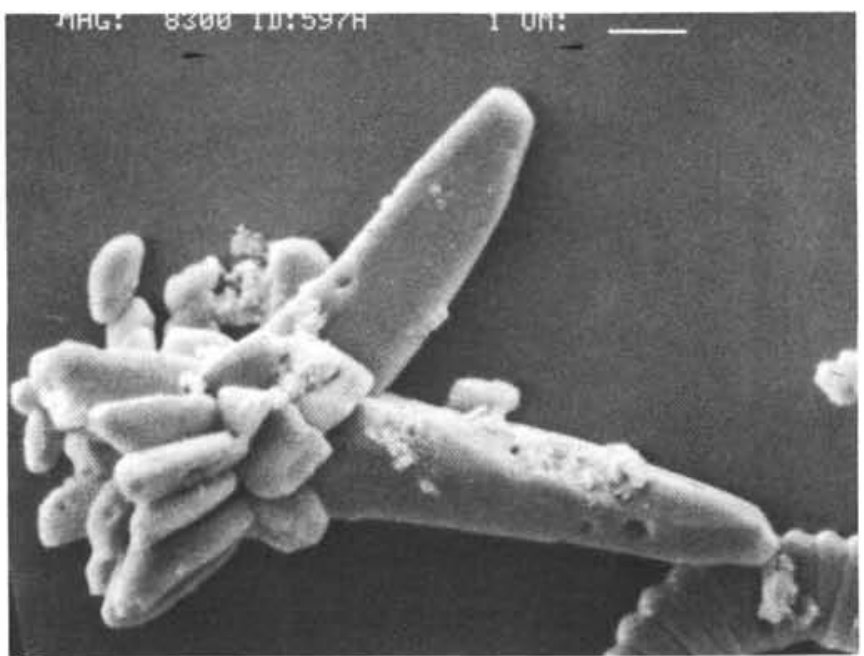

3

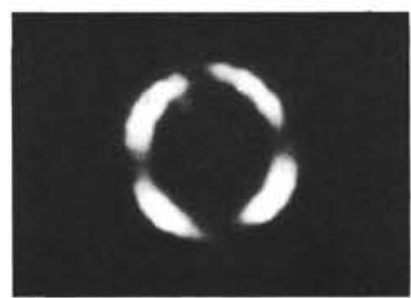

5

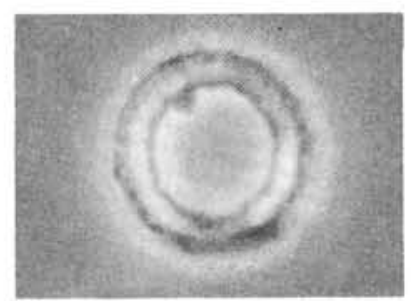

6
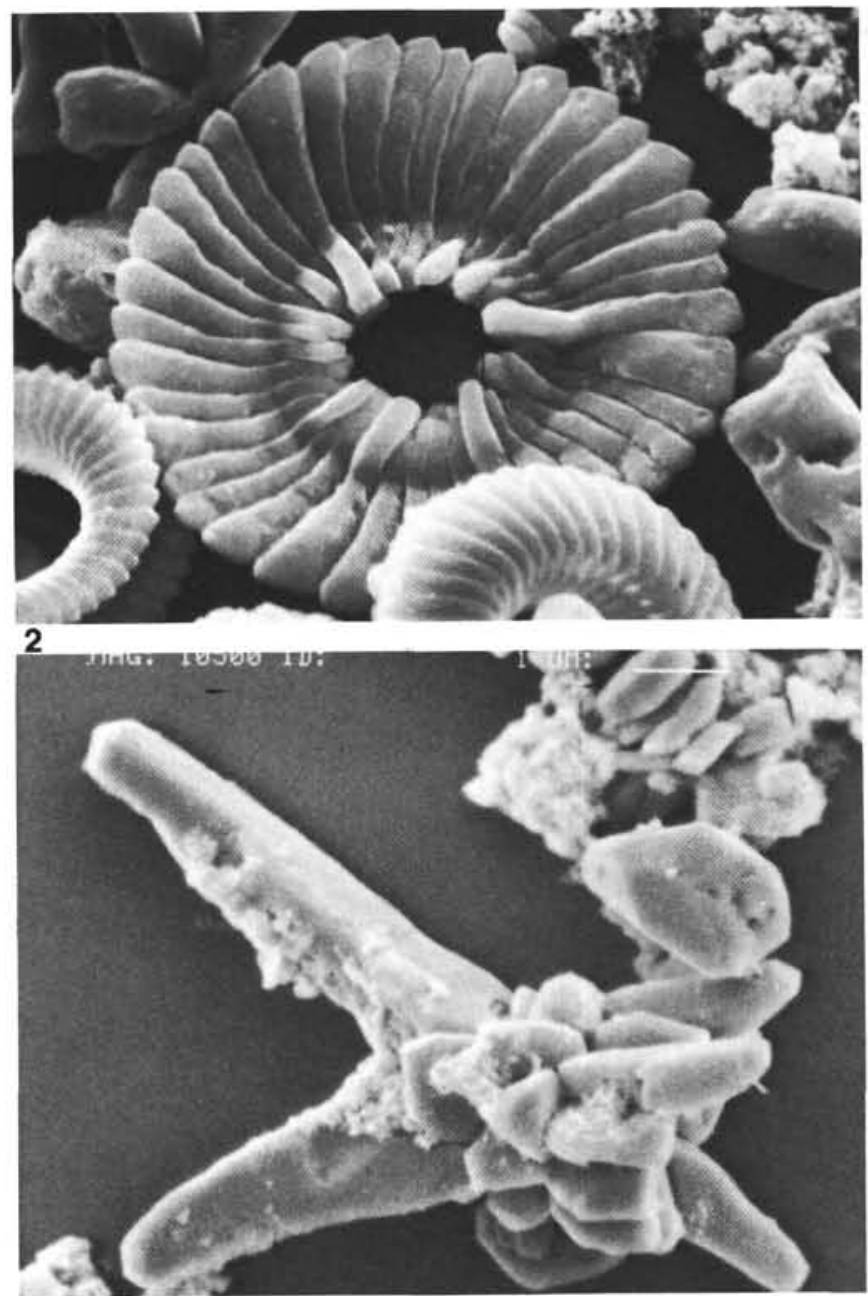

4

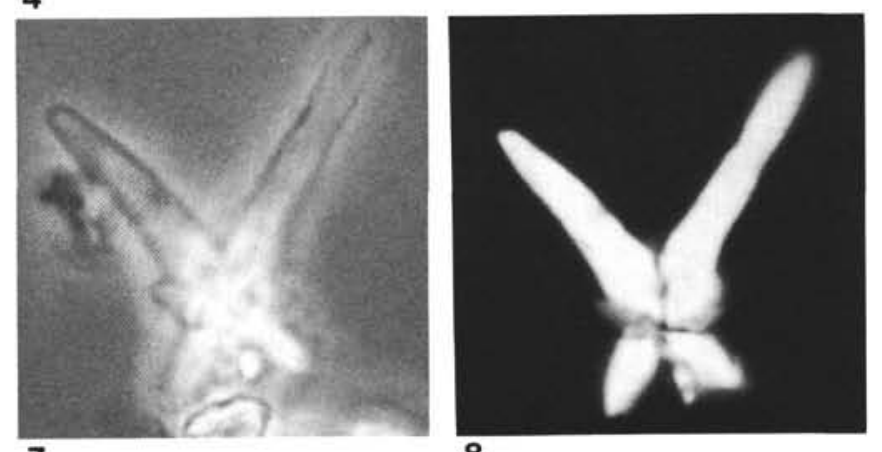

7
8

Plate 3. Late Oligocene and early Miocene nannofossils. 1. Discoaster druggii, Sample $597-3-4,56-57 \mathrm{~cm}, 2900 \times$. 2. Calcidiscus macintyrei s. ampl., Sample $597-1-3,56-57 \mathrm{~cm}, 6400 \times$. 3, 4, 7, 8. Sphenolithus capricornutus, Sample 597A-3-5, $56-57 \mathrm{~cm},(3) 8300 \times,(4) 10,500 \times,(7,8)$ $2900 \times$. 5, 6. Coronocyclus nitescens, Sample 597-3-4, 56-57 cm, $2900 \times$. 

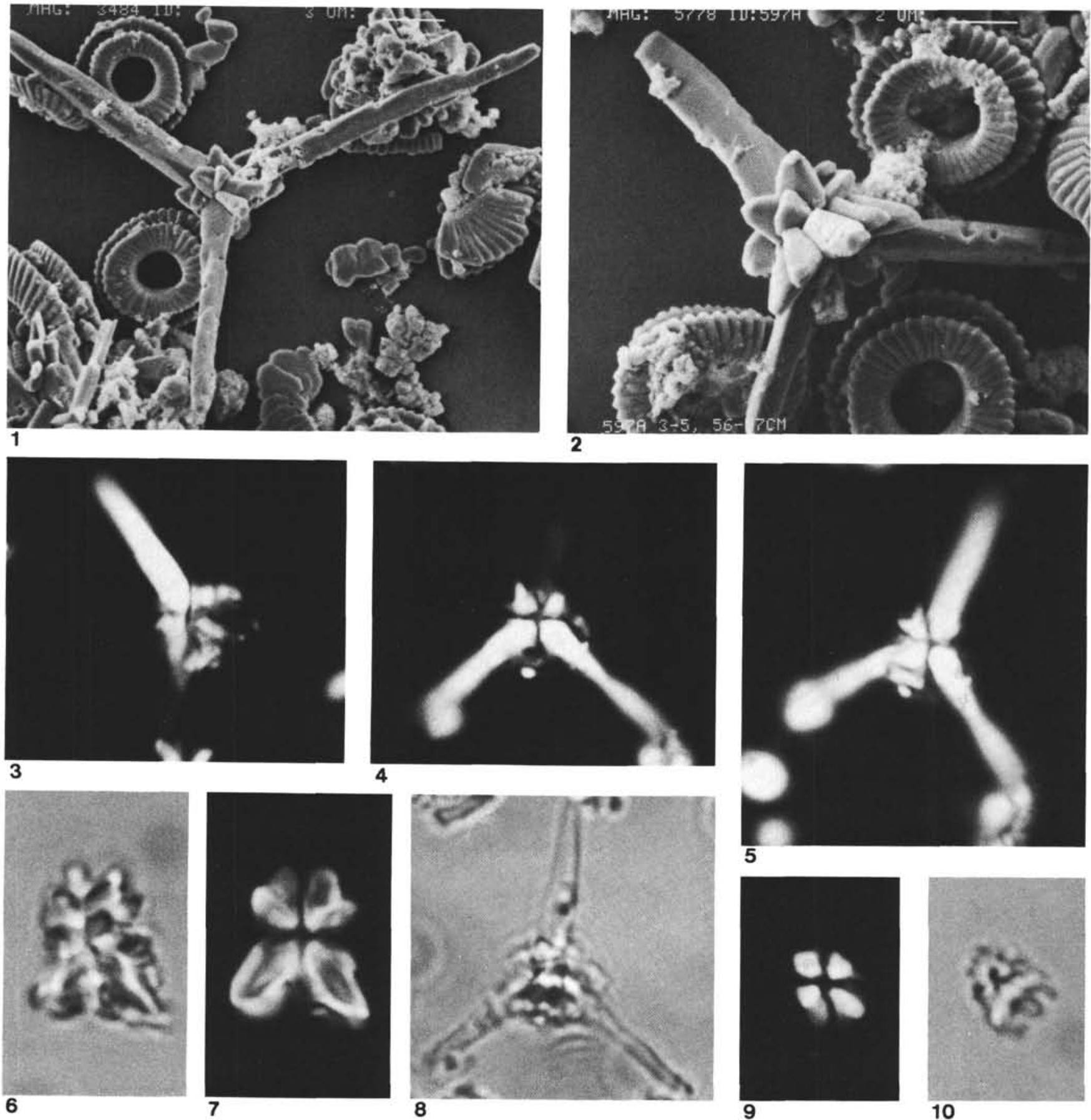

Plate 4. Late Oligocene and early Miocene nannofossils. 1-5, 8. Sphenolithus delphix, Sample 597A-3-5, 56-57 cm, (1) $3484 \times$, (2) $5778 \times$, (3-5, 8) $2900 \times$. 6, 7, 9, 10. Sphenolithus moriformis, Sample 597-3-4, 56-57 cm, 2900 $\times,(6,7)$ large form, $(9,10)$ small form. 


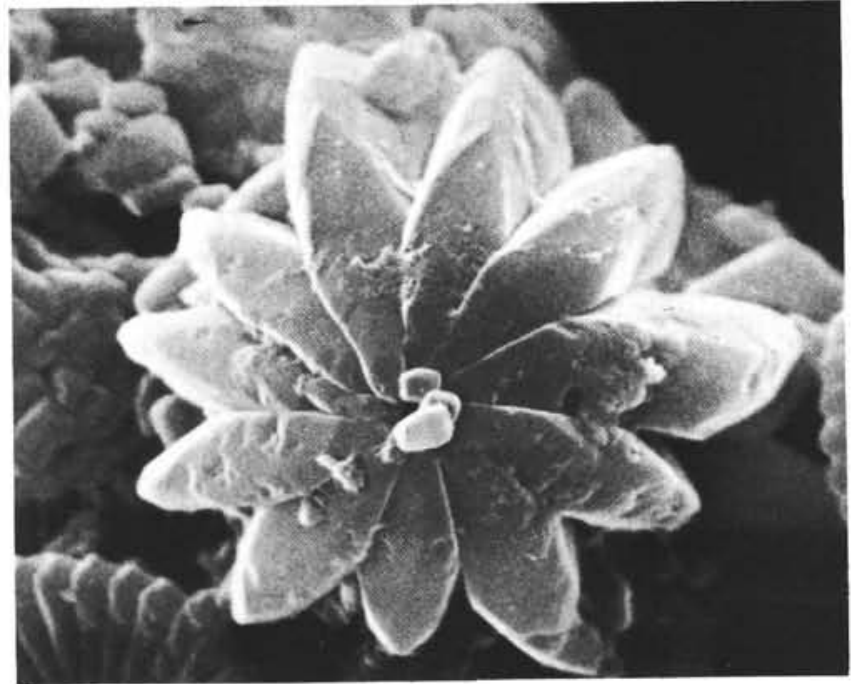

1

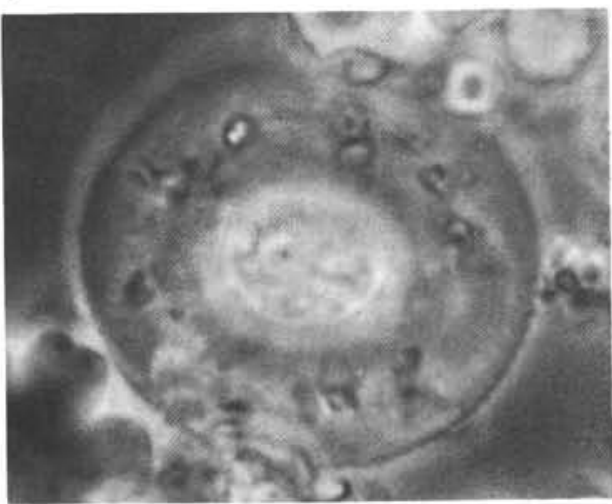

3

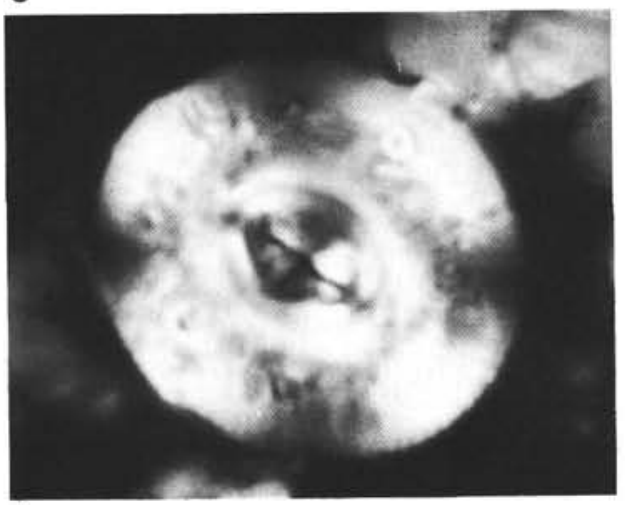

4

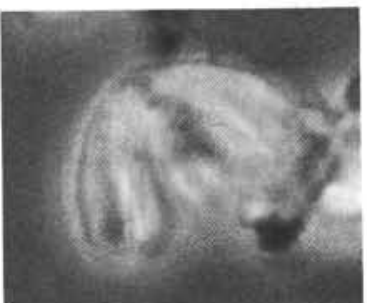

5

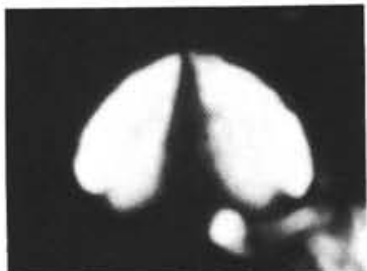

6

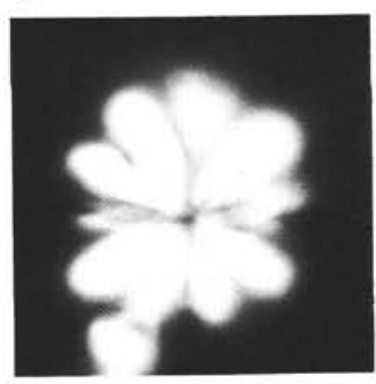

7
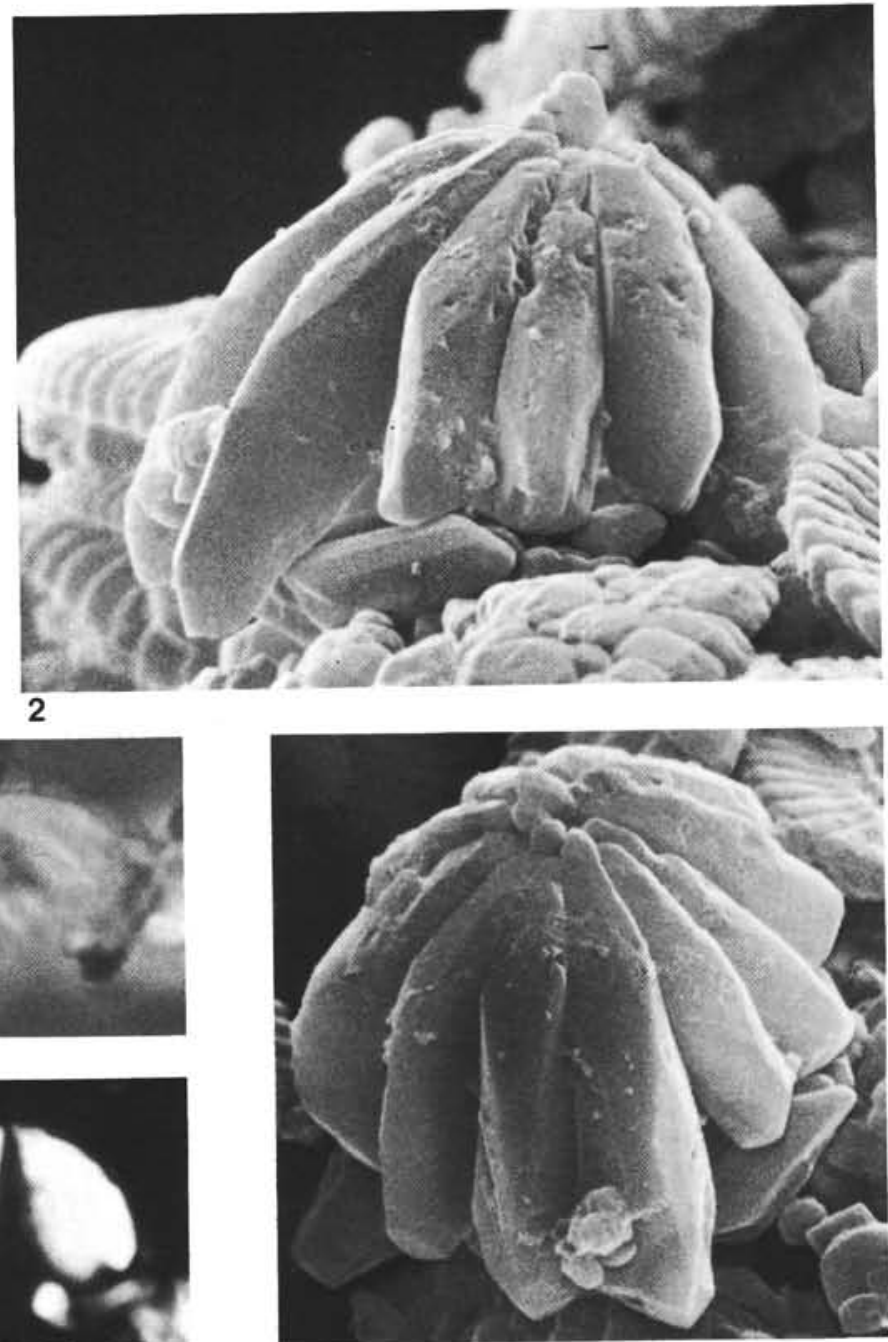

8

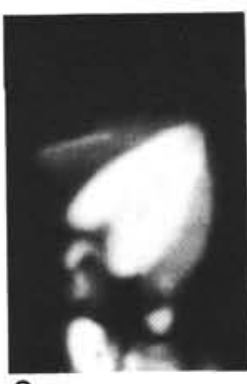

9

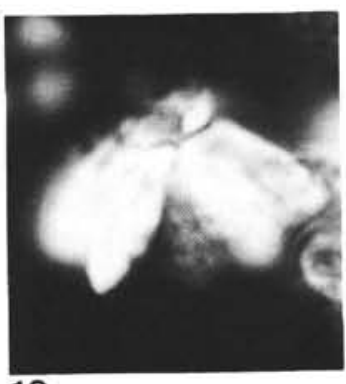

10

Plate 5. Late Oligocene nannofossils. 1, 2, 5-10. Sphenolithus umbrellus, $(1,2,8)$ Sample 597-4-2, 56-57 cm, $(1,8,700 \times ; 2,9100 \times$; 8, 7800× $)$, $(5-7,9,10)$ Sample 597-4-6, 56-57 cm, 2900×. 3, 4. Dictyococcites bisectus, Section 597-3,CC, 2900×. 


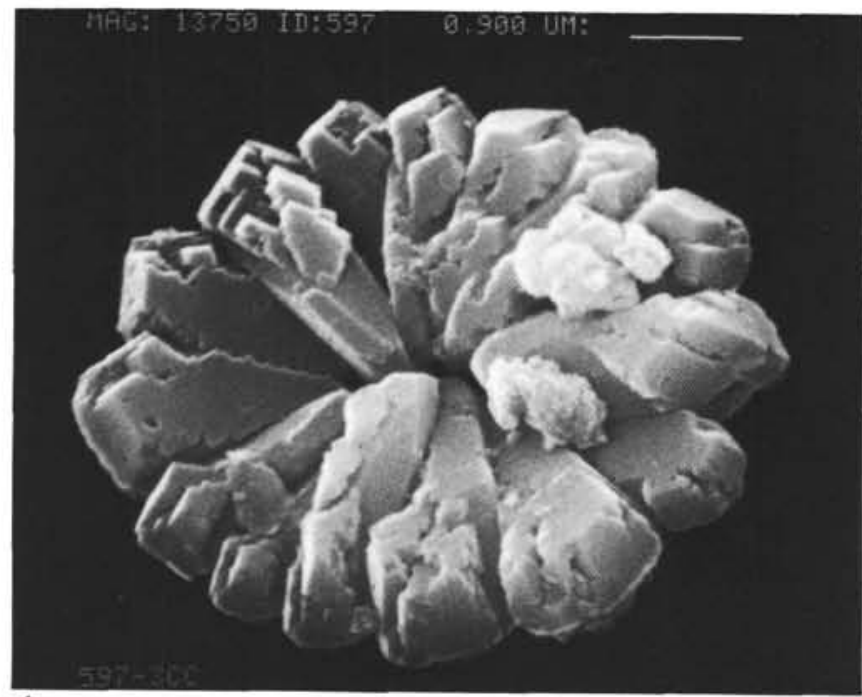

1

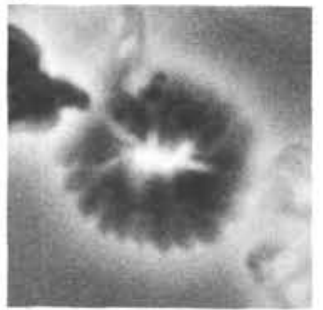

3

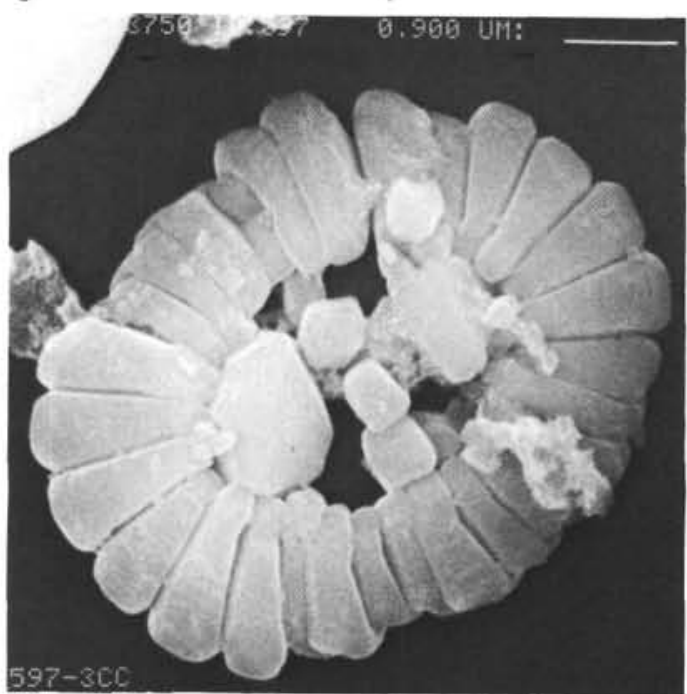

8

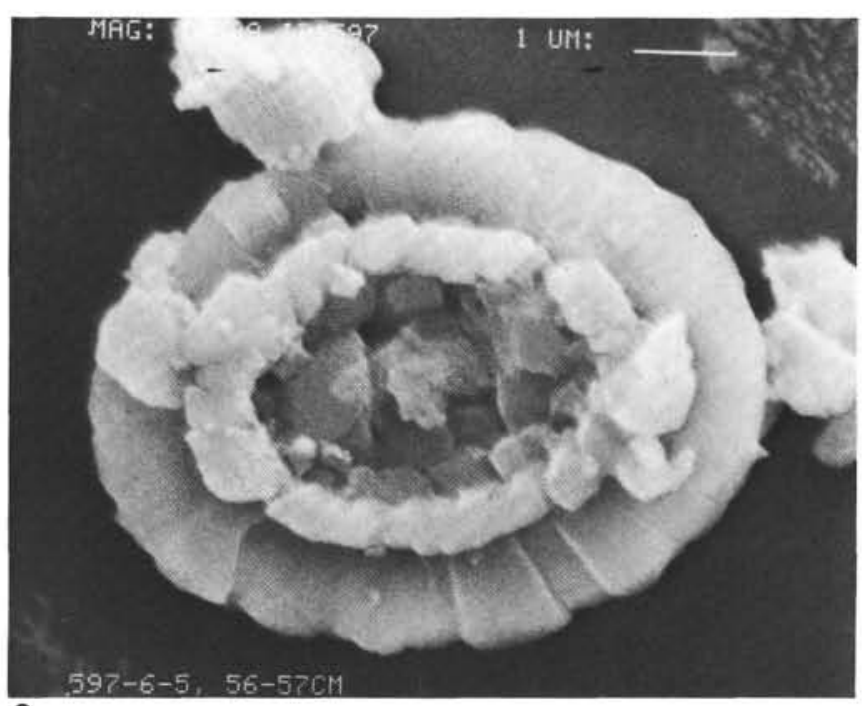

2

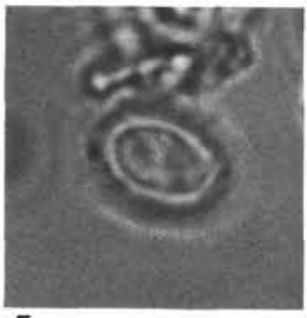

5

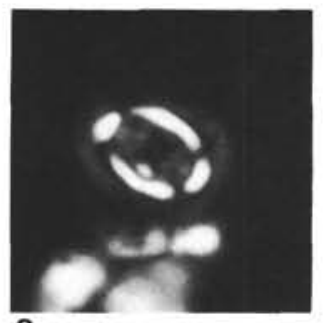

6

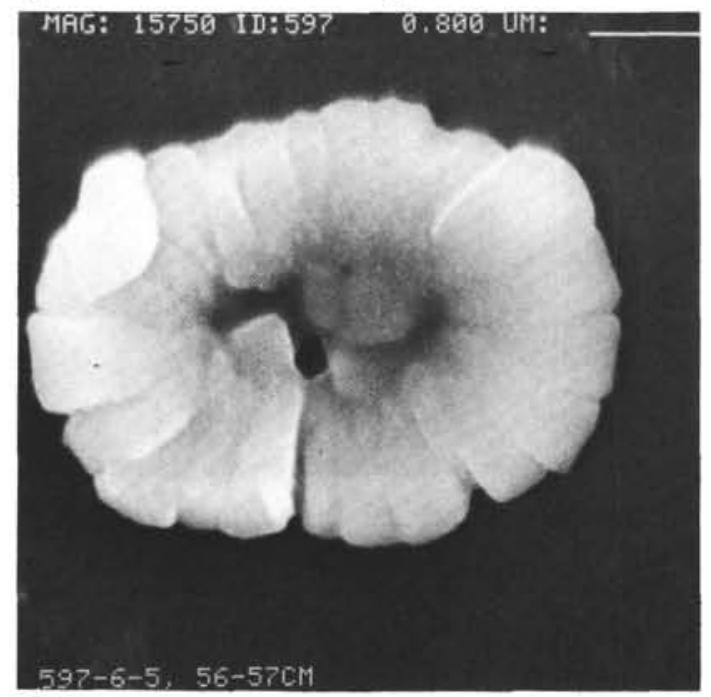

9

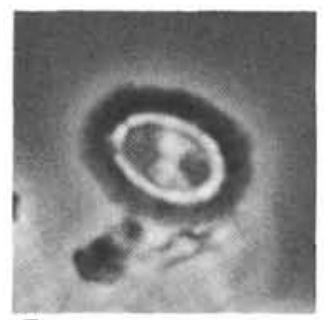

7
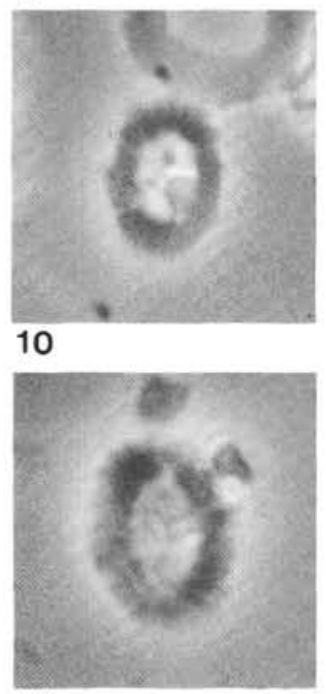

11

Plate 6. Late Oligocene nannofossils. 1, 3, 4. Coccolithus sp. (distal shield), (1) Section 597-3,CC, 13,750×, (3) Sample 597A-5-1, 90-91 cm, $2900 \times$, (4) Sample 597-4-6, 56-57 cm, 2900×. 2, 5-7. Clausicoccus fenestratus, (2) Sample 597-6-5, 56-57 cm, 10,989 ×, (5-7) Sample 597-4-6, $56-57 \mathrm{~cm}, 2900 \times$. 8-11. Coccolithus sp. cf. C. fuscus, (8) Section 597-3,CC, 13,750×, (9) Sample 597-6-5, 56-57 cm, 15,750×, (10) Sample $597 \mathrm{~A}-5-1,90-91 \mathrm{~cm}, 2900 \times$, (11) Sample 597A-4-3, 56-57 cm, $5150 \times$. 


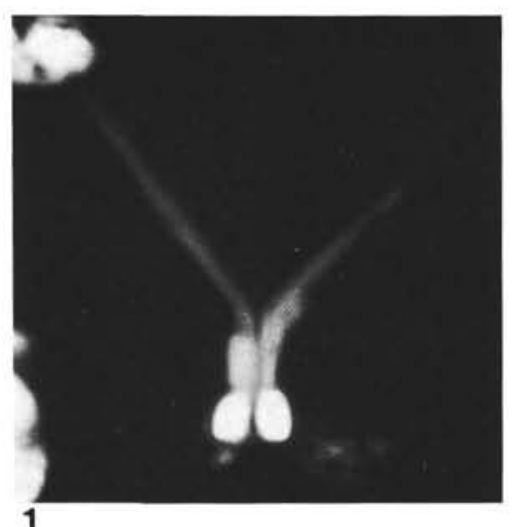

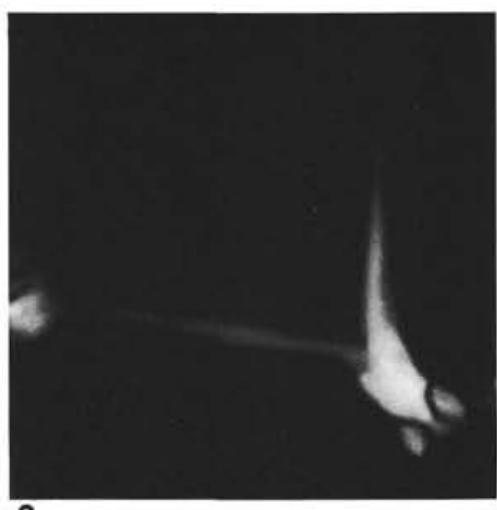

2

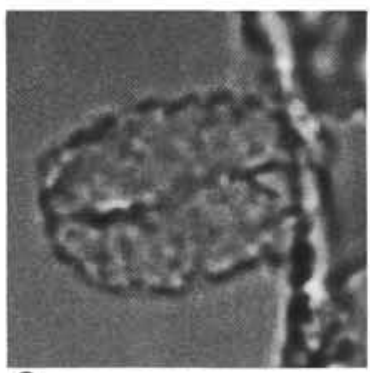

8

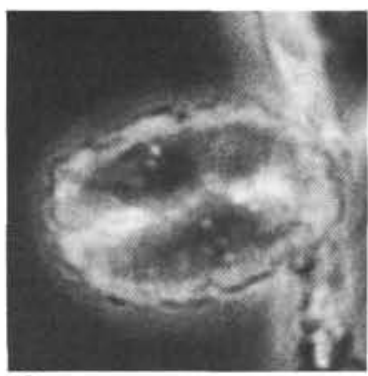

9

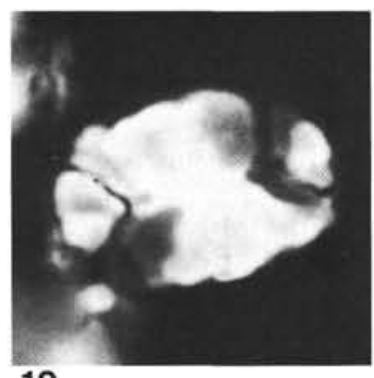

10

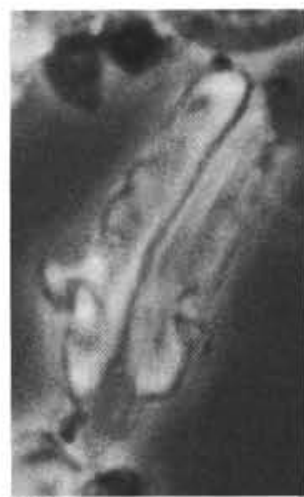

3

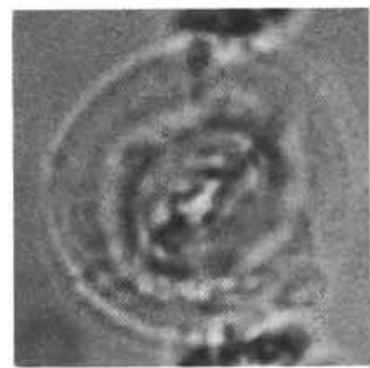

11

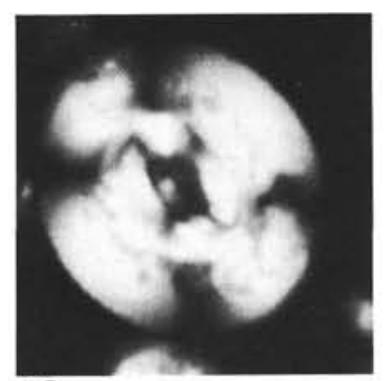

13

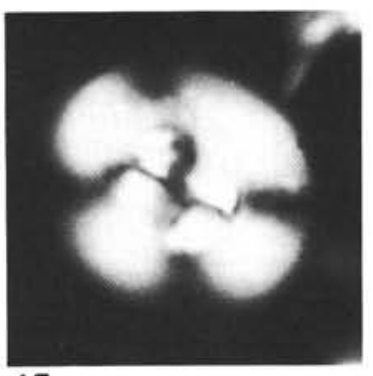

15

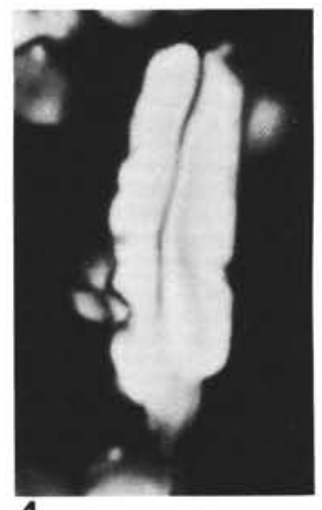

4

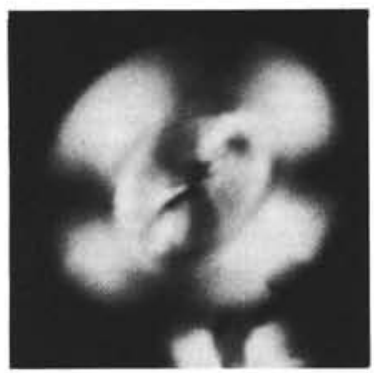

12

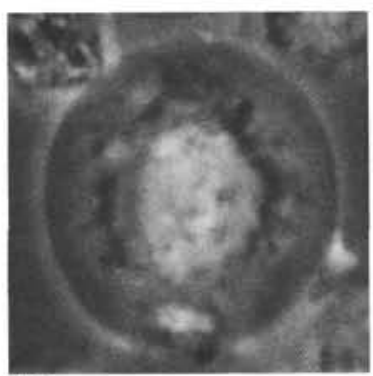

14

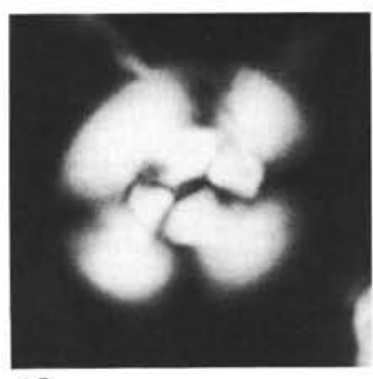

16

Plate 7. Late Oligocene nannofossils. 1, 2. Sphenolithus ciperoensis, Sample 597-4-6, 56-57 cm, $2900 \times$. 3, 4. Zygrhablithus bijugatus, Sample 597-4-6, 56-57 cm, $2900 \times$. 5-7. Helicosphaera intermedia, Sample 597-4-6, 56-57 cm, 2900×. 8-10. Pontosphaera segmenta, Sample 597-4-6, 56-57 cm, 2900×. 11, 12. Dictyococcites bisectus, Sample 597-4-6, 56-57 cm, 2900×. 13-16. Reticulofenestra sp., Section 597-3,CC, $2900 \times$. 


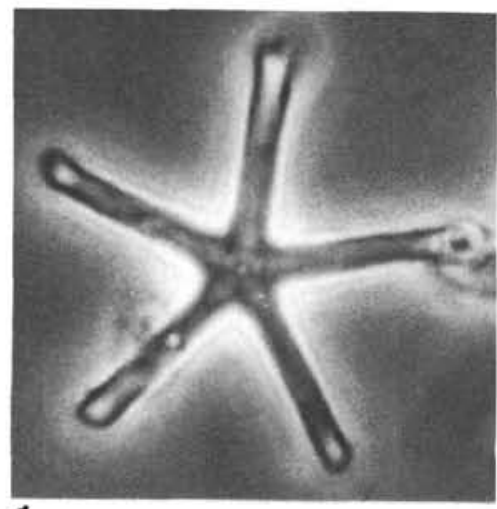

1

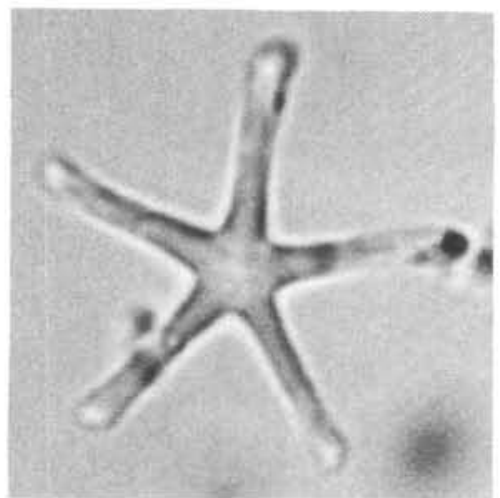

2

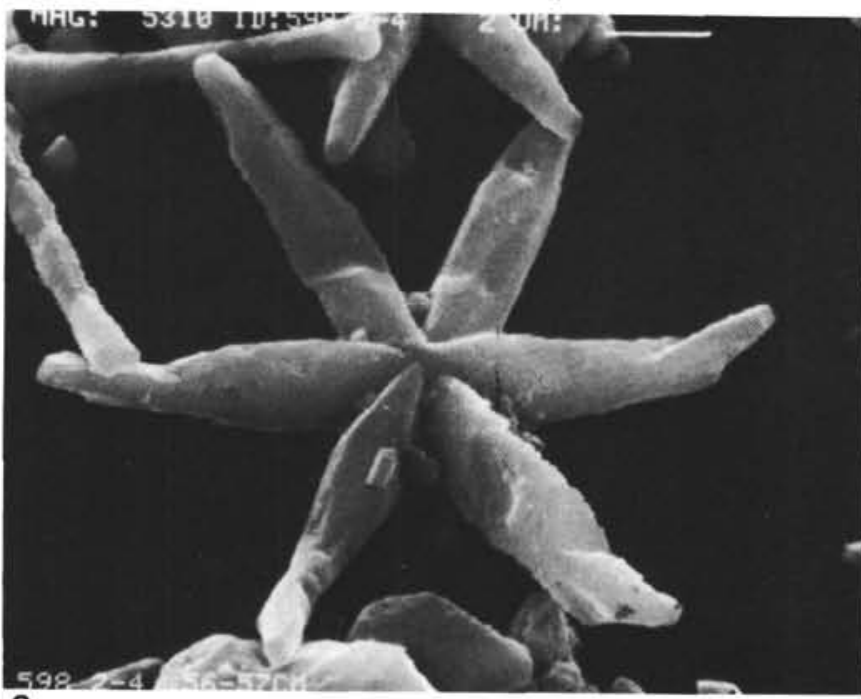

8

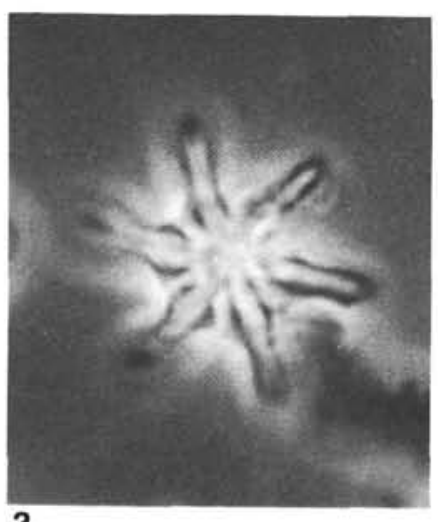

3
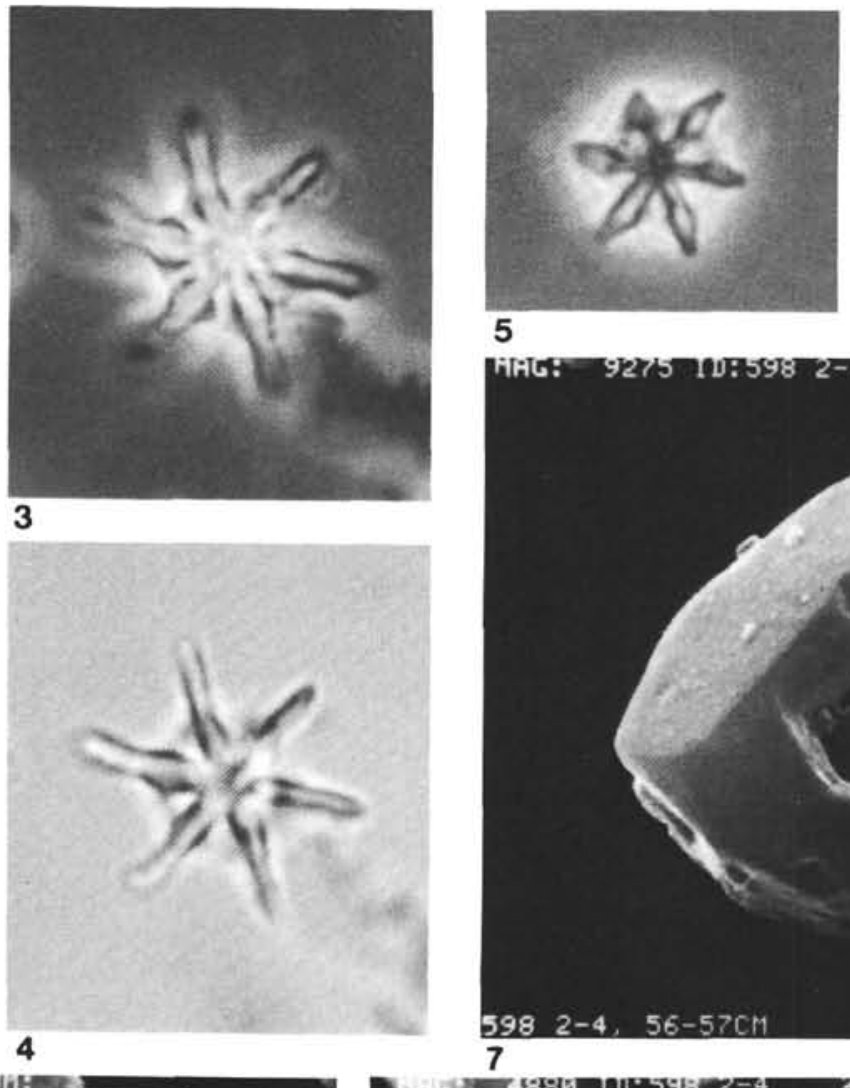

5

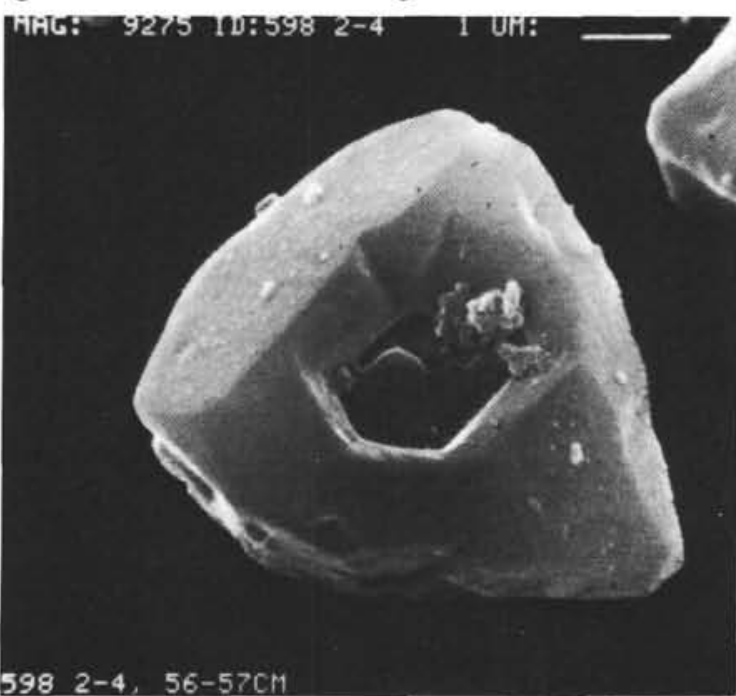

6

7

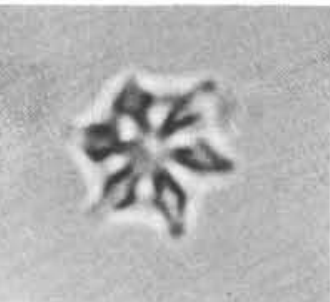

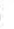

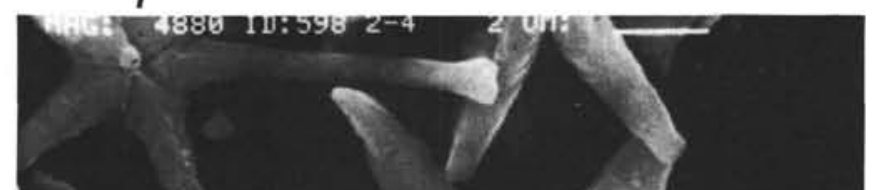

9

Plate 8. Middle and late Miocene nannofossils. 1, 2. Discoaster hamatus, Sample 598-2-6, 56-57 cm, 2900×. 3, 4. Catinaster calyculus, Sample 598-2-6, 56-57 cm, $2900 \times$. 5, 6. Catinaster sp. cf. C. calyculus, Sample 598-2-6, 56-57 cm, $2900 \times$. 7. Minylitha convallis, Sample 598-2-4, 56-57 cm, $9275 \times$. 8-9. Discoaster neohamatus, Sample 598-2-4, 56-57 cm, (8) $5310 \times$, (9) $4880 \times$. 

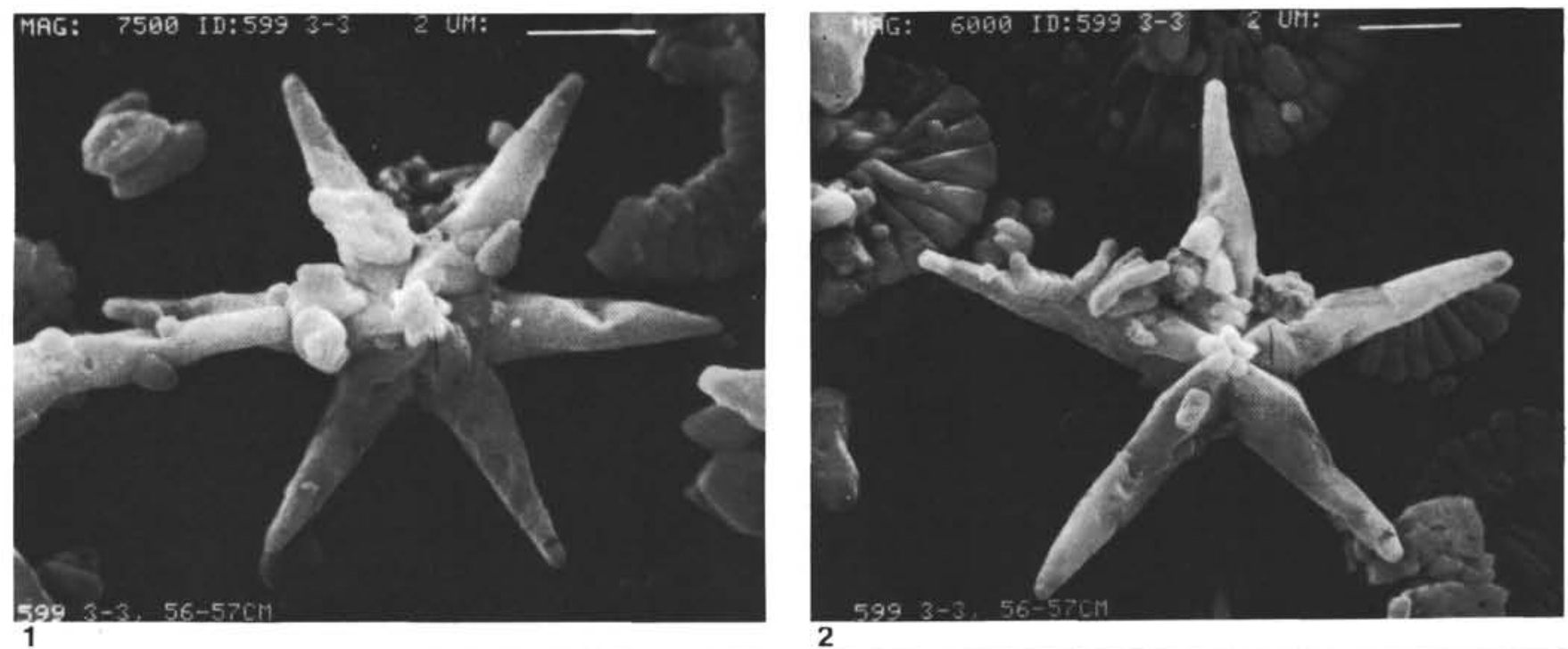

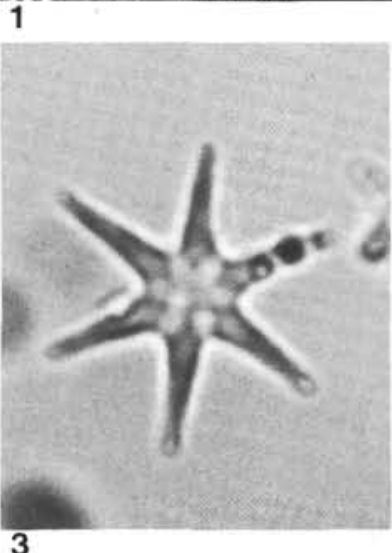

3

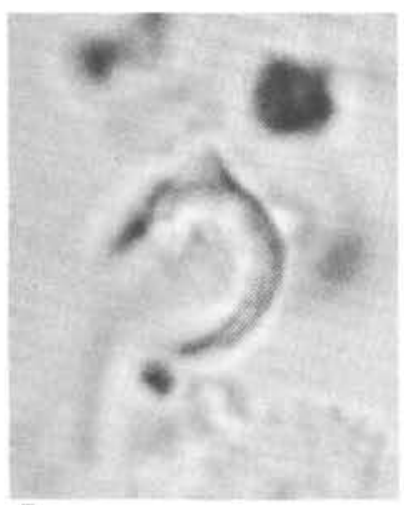

5

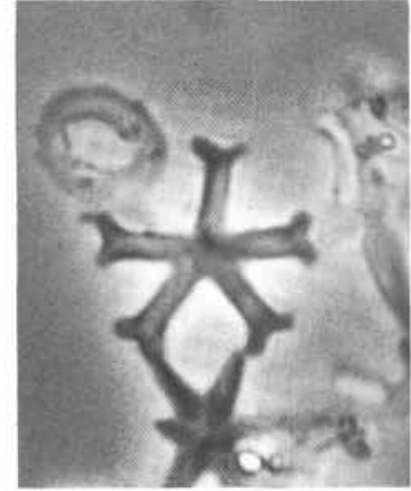

4

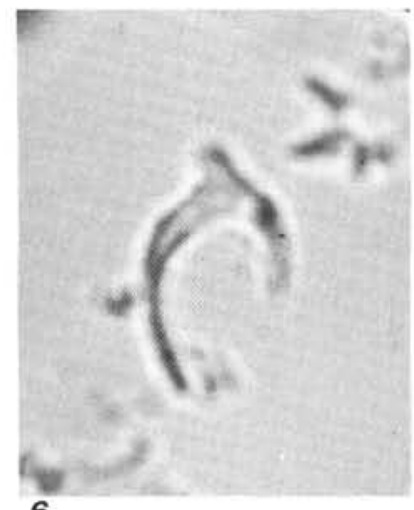

6
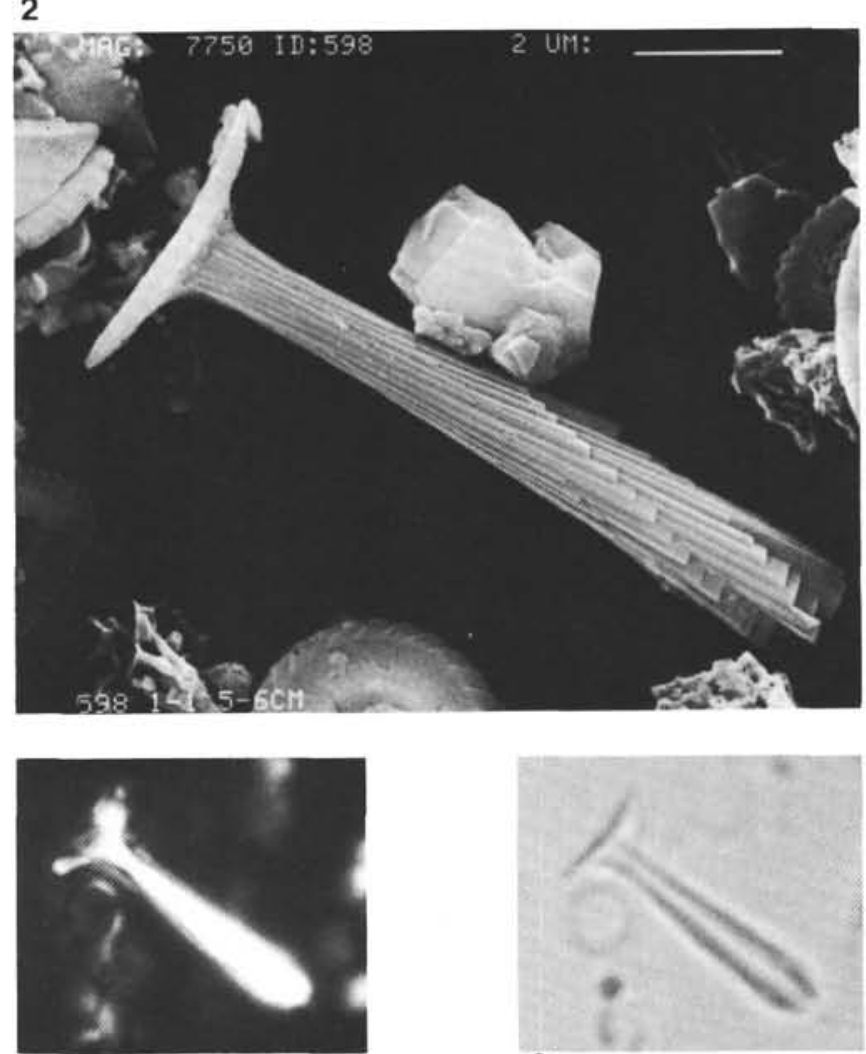

8

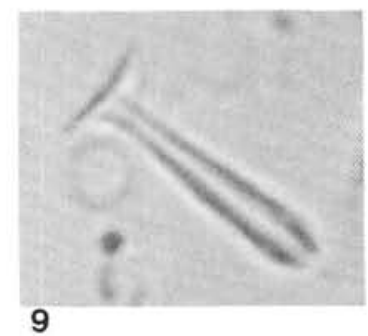

Plate 9. Late Miocene to Pleistocene nannofossils. 1, 3. Discoaster intercalaris, (1) Sample 599-3-3, 56-57 cm, 7500×, (3) Sample 598-1-2, 142-143 $\mathrm{cm}, 2900 \times$. 2. Discoaster quinqueramus, Sample 599-3-3, 56-57 cm, $6000 \times$. 4. Discoaster moorei, Sample 598-1-2, 142-143 cm, 2900×. 5. Amaurolithus sp. cf. A. tricorniculatus, Sample 598-1-2, 142-143 cm, $2900 \times$. 6. Amaurolithus tricorniculatus, Sample 598-1-2, 142-143 cm, $2900 \times$. 7-9. Rhabdosphaera clavigera, Sample $598-1-1,5-6 \mathrm{~cm},(7) 7750 \times,(8,9) 2900 \times$. 

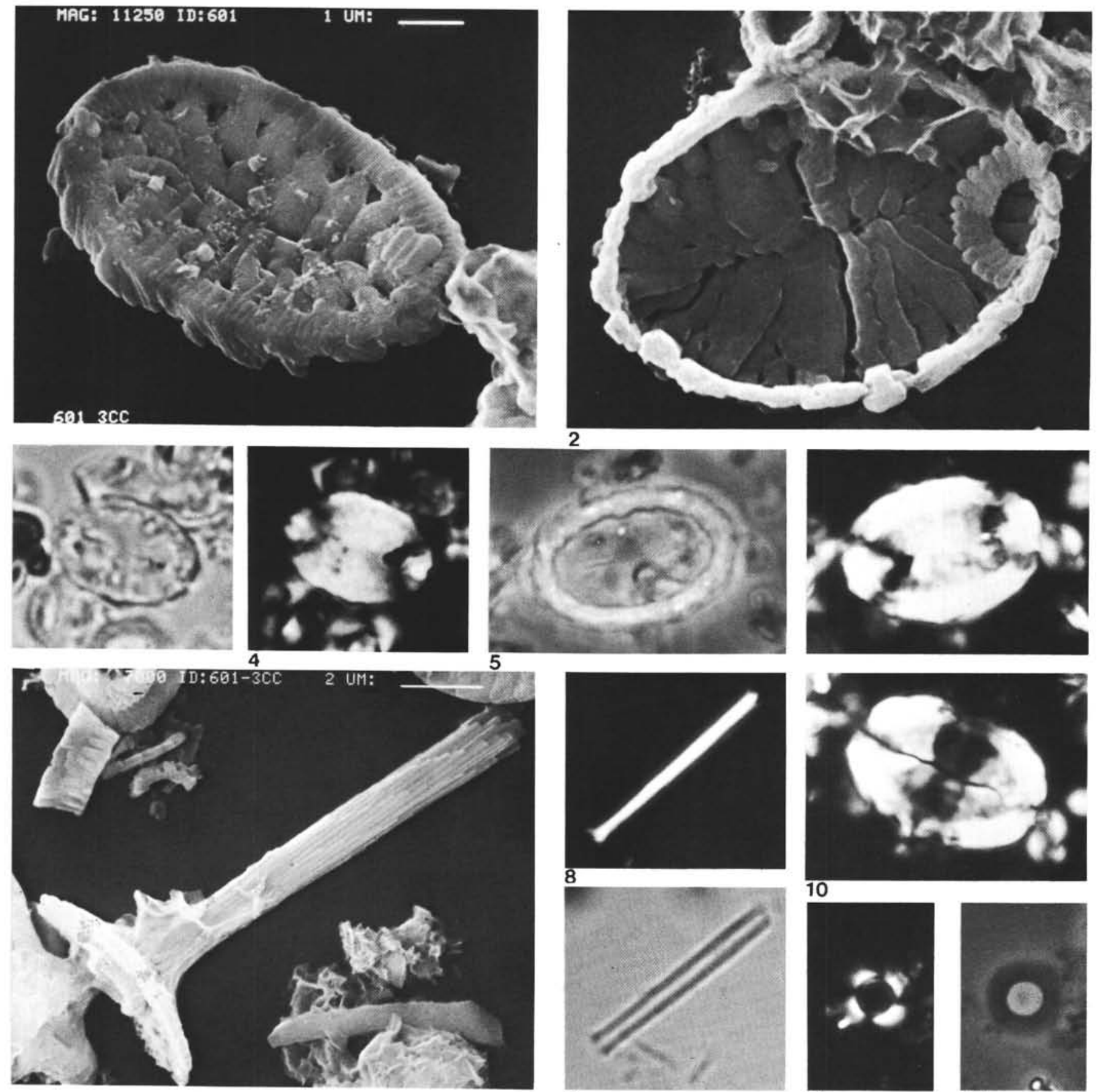

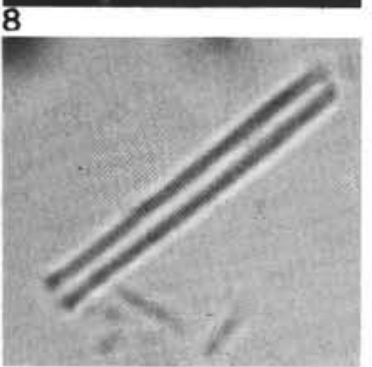

9

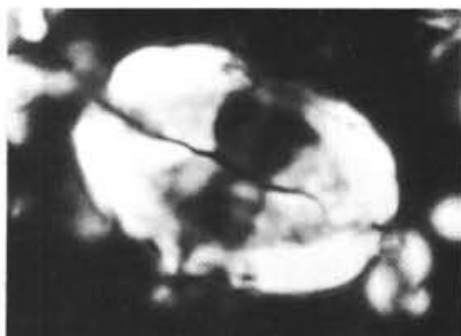

10

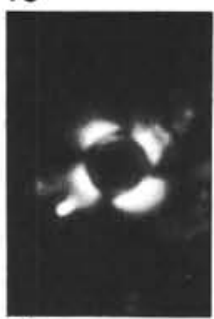

11

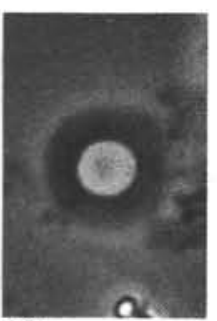

12

Plate 10. Pliocene and Pleistocene nannofossils. 1, 3, 4. Pontosphaera sp. 2, Section 601-3,CC, (1) $11,250 \times,(3,4) 2900 \times$. 2, 5, 6, 10. Pontosphaera sp. 1, Section 601-3,CC; (2) $7500 \times,(5,6,10) 2900 \times$. 7-9. Rhabdosphaera procera, Section $601-3$, CC, (7) $7000 \times,(8,9) 2900 \times$. 11, 12. Umbilicosphaera mirabilis, Sample 598-1-1, 5-6 cm, $2900 \times$. 

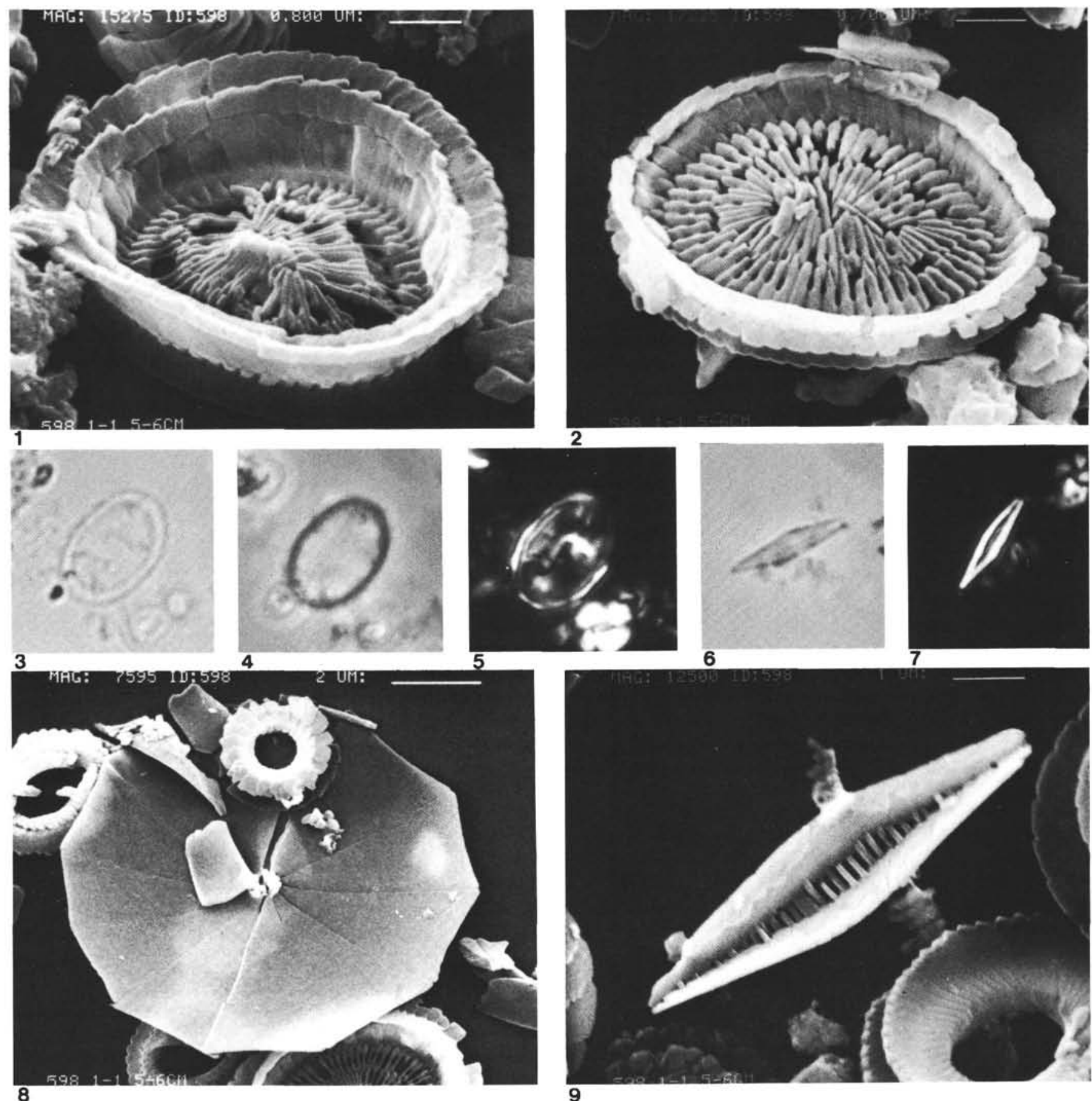

6

Plate 11. Pleistocene nannofossils. 1-5. Syracosphaera pulchra, Sample 598-1-1, 5-6 cm, (1) $15,275 \times$, (2) $17,225 \times$, (3-5) $2900 \times$. 6, 7, 9. Scapholithus fossilis, Sample 598-1-1, 5-6 cm, $(6,7) 2900 \times,(9) 12,500 \times$. 8. Hayaster perplexus, Sample 598-1-1, 5-6 cm, 7595 . 